Portland State University

PDXScholar

4-21-2004

\title{
Nurturing the Development of Teacher Change Agents Within a Teacher Education Program
}

\author{
Barbara Ruben \\ Portland State University
}

Follow this and additional works at: https://pdxscholar.library.pdx.edu/open_access_etds

Part of the Curriculum and Instruction Commons, and the Educational Leadership Commons Let us know how access to this document benefits you.

\section{Recommended Citation}

Ruben, Barbara, "Nurturing the Development of Teacher Change Agents Within a Teacher Education Program" (2004). Dissertations and Theses. Paper 1991.

https://doi.org/10.15760/etd.1990

This Dissertation is brought to you for free and open access. It has been accepted for inclusion in Dissertations and Theses by an authorized administrator of PDXScholar. Please contact us if we can make this document more accessible: pdxscholar@pdx.edu. 
NURTURING THE DEVELOPMENT OF TEACHER CHANGE AGENTS

WITHIN A TEACHER EDUCATION PROGRAM

by

BARBARA JO RUBEN

A dissertation submitted in partial fulfillment of the requirements for the degree of

\author{
DOCTOR OF EDUCATION \\ in \\ EDUCATIONAL LEADERSHIP: \\ CURRICLUM AND INSTRUCTION
}

Portland State University

(c) 2004 


\section{DISSERTATION APPROVAL}

The abstract and dissertation of Barbara Jo Ruben for the Doctor of Education in

Educational Leadership: Curriculum and Instruction were presented April 21, 2004, and accepted by the dissertation committee and the doctoral program.

COMMTTEE APPROVALS:
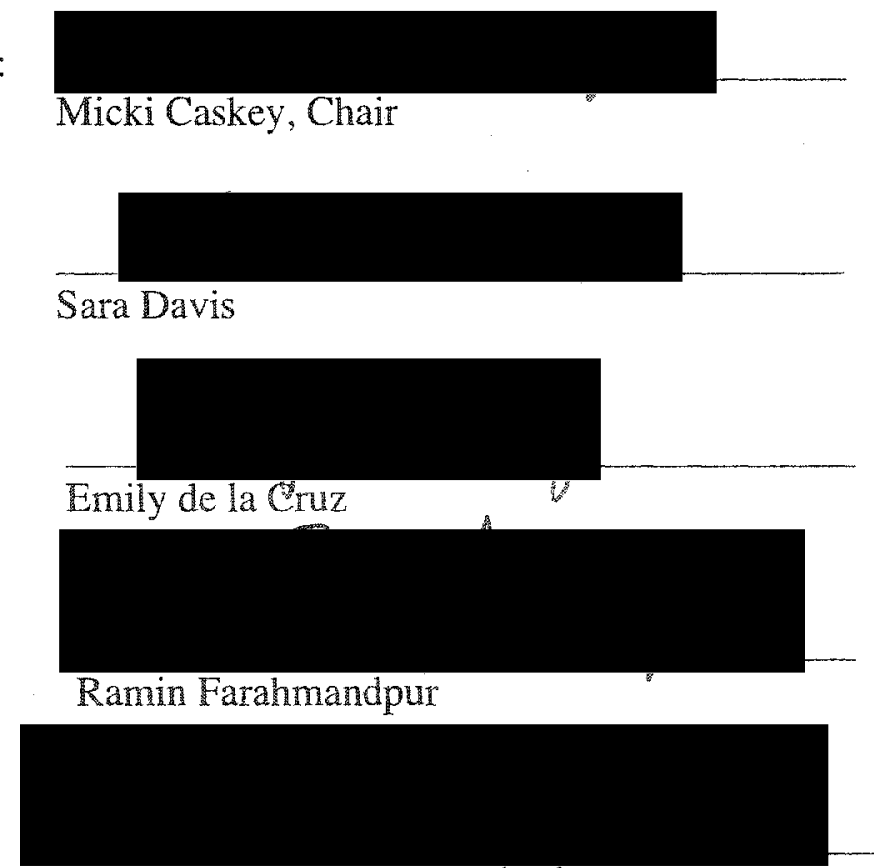

Dalton Miller-Jones

Representative of the Office of Graduate Studies

DOCTORAL PROGRAM APPROVAL

Phyllis J. Edmundson, Dean

Graduate School of Education 


\begin{abstract}
An abstract of the dissertation of Barbara Jo Ruben for the Doctor of Education in Educational Leadership: Curriculum and Instruction presented April 21, 2004.
\end{abstract}

Title: Nurturing the Development of Teacher Change Agents Within a Teacher Education Programs

The American education system has two daunting challenges. First, citizens need to be able to function in an interdependent world. Second, public schools' demographics have changed dramatically. Schools are failing to reach many students, particularly children of color and poverty. Schools must change to meet the needs of $21^{\text {st }}$ century students. Without teachers' openness to change, effective educational reform will fail. Schools of education must prepare the next generation of teachers to be change agents who will implement school reform to meet the significantly different requirements of $21^{\text {st }}$ century students.

This study examined how one graduate teacher education program prepared teachers to be teacher change agents. The construct of teacher change agent incorporates research on successful school reform. In order for teachers to function as 
change agents they must (a) be competent, (b) be lifelong learners, and (c) have a sense of agency.

A triangulation mixed-method design was used to examine a teacher education program's development of teacher change agents from various angles. The quantitative component of the study entailed the comparison of data from a scale administered at four different stages of teacher development. Graduates self-reported their frequencies of behaviors reflective of teachers open to change. The study's qualitative component included the examination of six professional portfolios, interviews with the portfolio's authors, and written responses to open-ended survey questions from a pool of 282 participants.

Findings showed that all participants reported at least moderate levels of behaviors reflective of teacher change agents. Each of the interviewees reflected all dimensions of teacher change agents. In the larger sample, areas of strength included caring for students' emotional and academic well-being, and reflecting on one's practice. Participants reported the most beneficial elements of their preservice experience to be the extensive fieldwork and the collaborative cohort model. The cohort model and working with inspiring professors who modeled deep caring for students helped sustain participants' passion for teaching. Areas of weakness included teachers' willing to give students voice, embracing ideas of colleagues and families, and using community resources to enhance their teaching. These areas need to be developed more fully in the preservice program. 


\section{DEDICATION}

To my father, Dr. Laurens Ruben, who has been my role model, as a person who followed his calling to both teach and conduct research. You and your father both showed me that one's "work" can also be one's passion. Thank you for believing in my ability to follow in your footsteps and for making it possible for me to pursue teaching and teacher research as a career path. 


\section{ACKNOWEEDGMENTS}

I want to thank Dr. Micki Caskey for her patience and calming presence with me throughout this four-year journey. It was a privilege and honor to be Dr. Caskey's doctoral student. I also want to extend my thanks to the rest of my dissertation committee members as well, Dr. Emily de la Cruz, Dr. Sara Davis, Dr. Ramin Farahmandpur, and Dr. Dalton Miller-Jones. I was very fortunate to work with a group of generous, bright people who were willing to let me stop into their offices unannounced to ask a probing question. On more than one occasion, one or another of them stopped me in the hall to recommend a book or article, or to encourage me along the way. A special thanks goes to Dr. Ken Peterson, who first encouraged me to explore teacher education and program evaluation as my dissertation topic and who spent hours exploring ideas with me and guiding me through some of the more difficult aspects of data analysis. I would like to extend my graticude to Tanya Ostrogorsky, who was a great help as I first attempted to understand and write about the quantitative portion of my study. Finally, I want to thank my husband Jeff, my children Samuel, Nathan, and my stepchildren Noah and Ariana, who all patiently saw me through the rough times. 


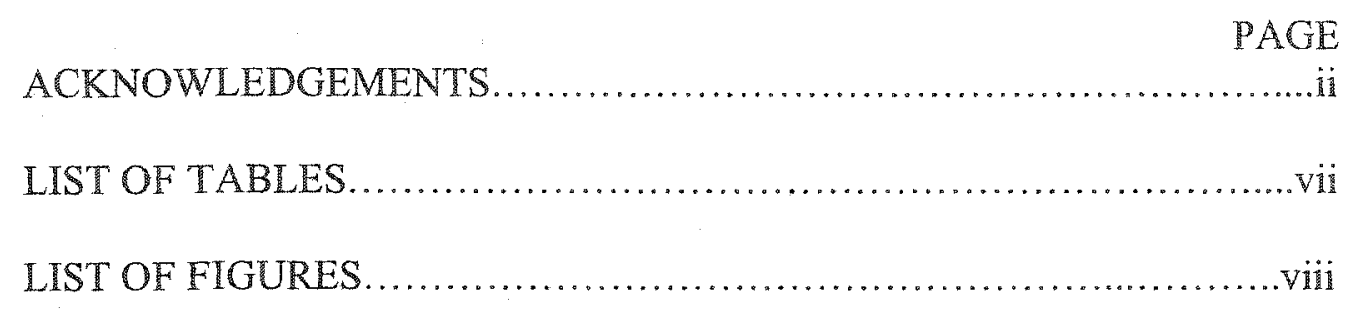

\section{CHAPTER}

$I$ INTRODUCTION........................................

The Problem Statement ............................ 1

The Purpose of Study.............................. 8

Research Questions ............................10

Sub-Questions

Theoretical Perspective...........................11

Definition of Terms..............................13

Significance of the Study............................ 19

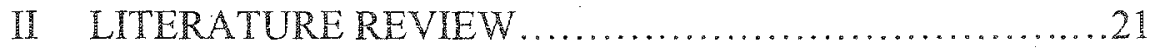

Educational Change and the Role of the Teacher.......21

Teacher Education and School Change...............28

Teacher Competence

Teachers as Learners

Teachers' Sense of Agency

Teacher Education Program Evaluation...............56

Literature Review Summary..........................64

III METHODS...........................................67

Review of Research Questions.....................67 
Program Description.

Socio-Political Context

Participants 75

Research Design. .79

Scale Data

Portfolio \& Interview Data

Focus Group Data

Instrumentation and Materials. .81

Scales

Survey and interview questions

Professional Portfolio Examination

Focus Group Questions

Procedural Sequence.

Variables in the Study

Data Analysis .87

Delimitation and Limitations of the Study. .91

Trustworthiness

IV FINDINGS. .94

Findings from Quantitative Data. .95
Sub-Question 1
Sub-Question 2
Sub-Question 3
Sub-Question 4

Summary of Quantitative Findings. 106

Qualitative Findings. 107

Open-Ended Responses. 107

Sub-Question 5 
Sub-Question 6

Summary of Findings From Open-ended

Responses...

Interviews and Portfolio Review... 124

Evidence of Teacher Competence. .125

Evidence of Lifelong Learning. 126

Sub-Question 7

Evidence of a Teacher's Sense of Agency 135

Summary of Overall Findings .143

V DISCUSSION. 146

Summary of Study. 146

Discussion of Research Questions. 149

Discussion of Sub-Question 3

Discussion of Sub-Question 4

Discussion of Sub-Question 5

Discussion of Sub-Question 6

Discussion of Sub-Question 7

Implications

Involvement with families and communities

Democratic Classrooms

Theory and Practice

Peer Collaboration

Relationships Building

Summary

Future Research Directions 163

Conclusions. 
A. TAMS: Teacher Adaptability Measurement Scale. 176

B. TAMS1........................................... 180

C. Individual Interview Questions..........................183

D. Portfolio Development Guide............................185

E. Questions for Focus Group Discussion.....................189

F. Table of Itemized Responses to TAMS ....................190

G. Table of Itemized Responses to TAMS1 ...................195

H. HUMAN SUBJECTS REVIEW ....................... 199 


\section{LIST OF TABLES}

TABLE

PAGE

1. Teacher Adaptability Measurement Scale: Table of Specification........83

2. Analysis Process and Rationale Behind Each Sub-Questions ..........89

3. Highest Frequency Responses of Inservice Teachers Reflecting Characteristics of Teachers-as-Change-Agents

4. Lowest Frequency Responses of Inservice Teachers Reflecting Characteristics of Teachers-a- Change Agents.

5. Highest Frequency Responses of Preservice Teachers Reflecting

Characteristics of Teachers-as-Change-Agent.

6. Lowest Frequency Responses of Preservice Teachers Reflecting

Characteristics of Teachers-as-Change-Agents................. 102

7. Descriptive Statistics: TAMS Subscales........................... 103

8. Comparison of Responses as to the Most Beneficial Program Experiences

9. Comparison of Responses as to What were the Least Helpful Program Experiences.

10. Responses as to Program Experiences That Sustain Their Passion for Teaching................................................119

11. Comparison of Responses as to Recommended Program Changes....122

12. Program Components Graduates Identified as Most Beneficial and Least Helpful..............................................147

13. Program Graduates Areas of Strengths and Weakness ...............148 


\section{LIST OF FIGURES}

FIGURE

PAGE

1. Exploration of the construct of teacher-as-change-agents within a teacher education program .................................... 12

2. Teacher-as-Change-Agent ................................... 15 


\section{CHAPTER I}

\section{INTRODUCTION}

\section{Problem Statement}

The American education system faces two daunting challenges. First, citizens need far more than the three Rs to participate in today's interdependent global society. Educated citizens face more complex tasks and responsibilities than at any time in history. As recently as $1950,90 \%$ of Americans held unskilled jobs. Fifty years later, only $10 \%$ of Americans hold jobs that do not require complex thinking skills (National Commission on Teaching and America's Future, 1996). Second, the demographics of public schools' have changed dramatically over the years.

The function of schooling has changed over the last 100 years. Tyack and Cuban (1995) chronicled that journey, "For over a century citizens have sought to perfect the future by debating how to improve the young through education" (p.1). They argued that education has always been a tool for social change. Tyack and Cuban stated, "Educational theorists have self-consciously used schooling to construct the citizens of that new order" (p. 2).

Throughout this nation's history one of the overriding goals of education was to cure social ills like poverty. During the 1960s, Tyack and Cuban (1995) reminded readers that President Johnson declared war on poverty asserting that "the answer to 
all our national problems comes down to a single word: education" (p. 2).

Unfortunately, schools failed to eliminate poverty. In the 1990 s the United States ranked the highest in levels of child poverty of all developed countries (National Commission on Teaching and America's Future, 1996). Tyack and Cuban cautioned that schools should not bear the entire burden for social change and, "Should not be scapegoats and are not panaceas" (p. 39). They described the debate over the purpose of American public education as, "a continuous process of creating and reshaping a democratic institution that, in turn helped to create a democratic society" (p. 142). The United States remains dependent on an educated citizenry to maintain democratic ideals. America's citizenry is the most diverse and complex than at any time its history.

Education in colonial United States was exclusively the right of white affluent males. It was many years before women were included and many more before people of color and the working class were allowed into the education mix. The education system remained stratified and hierarchical with distinctly different agendas for different social and racial members of the nation.

Education attempted to homogenize American culture (Levine, 1996). According to Levine, the goal was to implant Anglo-Saxon values on the entire population. Education was a tool for mixing up the "melting pot" of America's diverse population. For example, Levine described the goal of university Western Civilization courses during the first half of the 20 th century as, "homogenizing and normative: it socialized the young from whatever particularistic background tradition 
to a uniform standard thinking and behaving that ought to characterize America's expanding educated class" (p. 58). Despite the public school's best efforts, the melting pot never succeeded in merging the nation's people together into a monoculture.

Today, most urban schools consist of a majority of minorities, representing multiple languages and cultural perspectives. Despite the landmark U.S. Supreme Court's Brown v. Board of Education decision in the 1950s, school segregation persists and in fact has been on the rise since the early. 1990s (Tatum, 2003). Tatum points out the strong correlation with segregated schools and poverty. Most schools with high concentrations of children of color are also poverty level schools. Yet, $9 \%$ of the predominantly white schools are middle class. Tatum argues that segregation cuts off children of color from both educational and employment opportunities. All of these factors demand that public school teachers be highly trained to meet the sophistication and challenges of educating $21^{\text {st }}$ century children.

Educators are starting to recognize the strength diversity brings to all members of a learning community. Delpit (1995) explains elegantly the advantages of diversity within our classrooms, "The world would be diminished if cultural diversity is ever obliterated" (p. 39). She explains:

We begin with a perspective that demands finding means to celebrate, not merely tolerate, diversity in our classrooms. Not only should teachers and students who share group membership delight in their own cultural and linguistic history, but all teachers must revel in the diversity of their students and that of the world outside the classroom community. (p. 67) 
American public schools still have a long way to go before the rich diversity within our classrooms is celebrated. In the meantime schools lose too many students. In particular, African American, Latinos, and Native Americans drop out of high school at alarming rates (Greene, 2001). Many of the students who do finish high school and continue on to college are under prepared. Nearly one third of college freshman are required to take remedial courses before they can begin regular college curriculum (Paige, 2002).

For the next decade's graduates the future does not look any more promising. Only $40 \%$ of White fourth graders are passing reading proficiency tests. Nevertheless, the white students fare better than the rest of children. Only $12 \%$ of African-American and $16 \%$ of Latino fourth grade students are testing at acceptable levels in reading (Paige, 2002). The United States can no longer afford to exclude some students from the educational loop. The federal government mandates schools to address the needs of both a culturally diverse population, many of which are in poverty, as well as students with disabilities. At the same time schools are expected to raise test scores of all students, despite unequal and inadequate funding (Kozol, 1991; Mathis, 2003). Under the federally mandated "Leave No Child Behind Act" schools are under tremendous pressure to become more effective learning communities.

Despite the difficulties in teaching associated with poverty, research shows that teacher qualification is a stronger determinant of student achievement than poverty, language background, and minority status (Darling-Hammond, 1999; Hillard, 1991). Teacher education programs are obligated to prepare the next generation of teachers to 
respond to the significantly different requirements of the $21^{\text {st }}$ century educational landscape. Nieto (2002) writes:

We are living in a new century, a century different from any other in many ways, not the least of which is the tremendous cultural and linguistic diversity evident in our schools. Yet, the ways in which new teachers are prepared to face these differences, and the books used to help them have not changed enough. (p. xvii)

The National Commission on Teaching and America's Future (1996) echoes

similar concerns raised by Nieto. Their report states:

It is not just that educational demands are increasing, but that the very nature of learning is changing. Students must do more than learn new facts or cover more chapters, they must learn to integrate and apply their knowledge in more complex ways to more difficult programs. This means that teachers must accomplish very different things that require them to work in new ways. Consequently the nature of their preparation and the setting in which they teach must change substantially as well. (p. 13)

Public schools are not adequately prepared for the task. As Wagner (2002) explains, "The problem is not that schools are failing. Rather, the American system of education has become obsolete. No one is to blame, but we all share some responsibility for finding the solution" (p. 9).

Three seminal works had a tremendous influence on both school reform and teacher education reform. First, A Nation at Risk, (U.S. National Commission on Excellence in Education, 1983) prompted teacher education faculty to explore the role universities could play in improving what was being deemed a failed public school system. According to the report, schools were not adequately preparing students to compete in the global economy. Next, A report of the Holmes Group: Tomorrow's 
teachers (The Holmes Group, 1986) drafted by the deans of a number of education schools, outlined a series of recommendations for substantial reform in teacher preparation. Finally, the passage of the federal legislation No Child Left Behind (NCLB) in 2002 compelled significant changes in how public schools and schools of education look at educational reform.

NCLB is far reaching legislation that influences how schools measure learning, what specific curriculum schools use, and the definition of a "highly qualified" teacher. NCLB forces schools to disaggregate student data publicly, thereby exposing the extreme achievement gap between children of poverty and color compared to their white more affluent counterparts. For instance the dropout rate among Oregon's white children is $31 \%$, but the dropout rate for Latino children is $67 \%$ and African-American children is $51 \%$ (Greene, 2001). Without sufficient financial resources, it is unlikely that imposed accountability efforts, will eliminate the achievement gap. A serious negative consequence of NCLB's reliance on punitive measures and accountability through standardized testing is the loss of teachers" professional decisions related to curricula development that are relevant to their particular students. Furthermore, educational leaders report heavy reliance on standardized tests forces schools to redesign curriculum to "teach to the test̂" (Goldberg, 2004; Jorgenson \& Vanosdall, 2002; Nathan, 2002).

In addition, NCLB demands that only curriculum tested with "scientifically based research" be used to guide teacher practice (U. S. National Commission on Excellence in Education). Much controversy exists over the federal government's 
limited definition of what constitutes "scientifically based research." Researchers argue that effective curricula options studied with qualitative research methods are discarded as a consequence (Yatvin, 2002).

NCLB attempts to address the problem of unequal access to effective teachers for students of color and poverty. The Act requires schools to report the unequal representation of highly qualified teachers among communities. Haycock (1998) reports that poor students of color have significantly higher probability of being taught by a teacher who does not hold a degree in the subject they teach. Twenty-five percent of children in poverty have teachers without degrees in their subject. In schools with low concentrations of poverty $15 \%$ of students have unqualified teachers. Twenty-two percent of students in high minority schools have unqualified teachers, while students in white schools have $16 \%$ of their courses taught by unqualified teachers. In response to this inequality in teacher qualifications, the authors of NCLB have redefined what it means to be a "highly qualified teacher." In addition, Department of Education Secretary Paige advocates for a more streamline system of certification requiring only subject matter knowledge and the passage of a standardized exam with no actual pedagogical instruction (U.S. Office of Postsecondary Education, p. 15). Numerous studies refute Paige's position and provide evidence that teachers need to know more than just content knowledge to effectively reach all students (Darling-Hammond, 1999; Darling-Hammond, 2001; Darling-Hammond, 2002; National Commission on Teaching and America's Future, 1996). The consequence of the federal definition of 
"highly qualified teacher" forces professional schools of education to demonstrate their value in the development of qualified teachers.

Regardless of the merits of NCLB, it is a fact that American public schools are not meeting the unique educational needs of all its students. Teachers are the key to changing schools to better address the demands of $21^{\text {st }}$ century (Darling-Hammond 1999). Schools of education need to know how to prepare teachers to be ready to participate in the change process. Currently, there has been little research conducted to determine the effectiveness of teacher preparation programs in developing teachers as change agents who will help bring about those changes.

Education reform is essential to meet the needs of $21^{\text {st }}$ century students. Educators must address the requirements of the United States' diverse population, in order to prepare them to live within a global complex interdependent world. However, many teachers fail to recognize the urgency for educational reform; among those who do embrace change in theory, some are resistant to adopt it in practice. Unless teachers are open to the possibility of change, schools will be incapable of implementing significant educational reform (Elmore, 1995). Without teachers' ownership of the educational reform, it will fail (Sikes 1992; Spencer, 1996; Stoll, 1992). Teacher education programs must prepare the next generation of teachers to be integral key participants in the change process.

\section{Purpose of Study}

The purpose of this study is to examine how one graduate teacher education program prepares teachers who will be open to change and assist their schools in 
moving beyond superficial reform to new ways of thinking. Researchers identify the key components to successful implementation of school reform as: teacher collaboration, openness to continuous growth and learning, reflective analysis, and a teacher's sense of agency. This study offers insights to teacher education program designers on how to identify the most effective means to enhance the ability of new teachers to be strong agents of change.

The teacher education program under examination was redesigned in 1989 to reflect most of the Holmes Report recommendations. Four key elements of the program's reforms were: (a) teacher education became exclusively a graduate level option, (b) a cohort model of interdisciplinary teaming was instituted, (c) reflective practice was emphasized, and d) a strong commitment to preparing teachers to work in diverse urban environments became the school's mission. The goals for the teacher education program, as described by the core faculty were, "to prepare educators who are strong subject matter experts, sensitive to the contexts in which they teach, and ready to both study and change the educational system in which they work" (Narode, Peterson, Petrie, Rennie-Hill, \& Sherman, 1991, p. 2). The program has licensed more than 1,500 new teachers since its inception. How successful has the program been in meeting the goal of preparing teachers to work toward education reform?

The teacher education program was examined to determine its ability to nurture teacher change agents through the infusion of the following elements: (a) a collaborative cohort model, (b) a thorough grounding in constructivist learning theory, 
(c) an emphasis on reflective analytic practice, and (d) the nurturing of a sense of agency in its preservice teachers.

When novice teachers exit teacher education programs to join a public $\mathrm{K}-12$ school culture, they face many factors that may inhibit their original idealistic aspirations. School cultures are particularly resistant to change. This resistance to change is a result of a variety of actions including teacher isolation from their colleagues as well as the rest of the school community and parents. Frequently, teachers lack ownership in the change process and feel those who do not understand the needs of their students are externally placing change on them. They do not feel respected as professionals or feel their voices are heard within the school reform process.

The purpose of this study was to explore the possible role teacher education programs have in preparing future teachers who will help change the culture of schools to be authentic learning communities, places where teachers work collaboratively to meet the unique needs of their students.

\section{Research Questions}

What influence does a teacher education program have on the development of future teacher change agents?

\section{Sub-questions}

1. In what ways do the program's graduates perceive themselves as change agents? 
2. What is the effect of the teacher education program on graduates' ability to be collaborative team players?

3. What is the effect of the teacher education program on graduates' ability to be lifelong learners?

4. How do teacher perceptions differ based on teaching experience?

5. What elements of the teacher education program do graduates feel prepared them for working within schools going through major school reform?

6. What elements of the teacher education program do graduates feel hindered their preparation for working in schools undergoing major school reform?

7. How do the perceptions of teachers-as-change agents differ based on whether they are working in a school that has established a professional community with shared norms of collaboration?

\section{Theoretical Perspective}

The study was designed to explore the elements of a specific teacher education program that facilitate the development of teachers as change agents. The theoretical premise underlying this research is the construct of teacher-as-change agent and the role teacher education programs can play in the development of that construct. Various elements of the teacher education program have been examined to determine their significance in the development of teachers as change agents.

This descriptive study used a triangulation mixed method design to provide a more complete, complex picture of the issues involved in teacher preparation for the development of teacher change agents (Creswell, 2002). Both quantitative data and 
qualitative data were collected simultaneously and were held as equal weight in exploring the research questions (see Figure 1). In the analysis of the quantitative segment of the study, the design of the teacher education program was considered the independent variable and the score on a measurement scale of teacher adaptability was the dependent variable. In analysis of the qualitative data, written responses, interview transcripts, and portfolios were examined for evidence of the three components of the construct of teachers as change agents. Obtaining both quantitative and qualitative data allowed the researcher to identify areas of convergence, inconsistencies, and areas where the results are complementary.

Figure 1. Exploration of the construct of teacher-as-change-agents within a teacher education program.

Quantitative

Data (Scales)

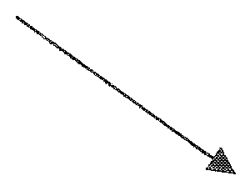

Qualitative

Data

(Portfolios, interviews, open-ended survey responses, focus group)

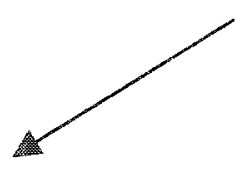

Interpretation

Interpretation of data allowed the researcher to examine the effectiveness of the development of the construct of teacher change agent within a teacher preparation program. 
Definition of Terms

The terms "teacher-as-change-agent" and "educational reform" need clarification.

Teacher-as-Change-Agent.

In this study, "teachers-as-change-agents" refers to teachers who have the disposition to advocate for changing their school's practice when it no longer meets the unique needs of their students. Havelock (1995) defines "change agent" as "someone who tried deliberately to bring about a change or innovation in a social organization" (p. 21). He details a seven-stage theory for planned change.

The initial phrase is when the change agent cares deeply about an educational issue. From that place of deep caring, the teacher as change agent builds relationships, acquires resources, tries out possible solutions, and extends or diffuses his/her ideas. In the final stage the teacher renews his/her commitment to the change. Based on Haverlock's work and others who study teachers' role in educational reform, the researcher identifies three dimensions to the construct of teacher-as-change agent (Elmore, 1995; Little, 1982; Marks \& Louis, 1997; O'Hair \& Reitzug, 1997; Wynne, 2001) (see Figure 2). The three dimensions of teachers as change agents include:

1. Competence: teachers with strong content knowledge, pedagogical content knowledge, and knowledge of how humans learn (Darling-Hammond, 1997b; Shulman, 1987; Wynne, 2001). Using the current understanding of how humans learn, competent teachers use a student centered, constructive model of 
instruction (Bransford, Brown, \& Cocking, 2000). Windschitl (2002) defines

constructivist instruction and student-centered teaching as teaching that:

...Allows students to use their own interests as one of the bases of classroom activities, that encourage productive student-student dialogue in the quest of meaning making, and that supports the collaborative development of unique products that are evidence of understanding. (p. 165)

2. Lifelong-learner: teachers who take risks, collaborate with peers, and reflect deeply on their practice, bringing personal relevance and meaning to the subject; teachers who perceive their role as one of co-learner in the classroom. Teachers who are learners are open to being part of professional learning community and work to establish a community of learners within their classrooms and schools (Bransford et al., 2000; Little 1982; Louis \& Marks, 1998; Wynne, 2001).

3. A sense of agency: teachers who have strong self efficacy, who are empowered to make a difference, who believe they are capable of making the changes necessary to provide equitable democratic schools for their students. These teachers respect and listen to the voices of their students and their families (Danielewicz, 2001; Hansen, 1999; Nieto, 2002; Quartz \& TEP Research Group, 2003; O'Hair \& Reitzug, 1997; Wynne, 2001) 
Figure 2. Teacher-as-Change-Agent

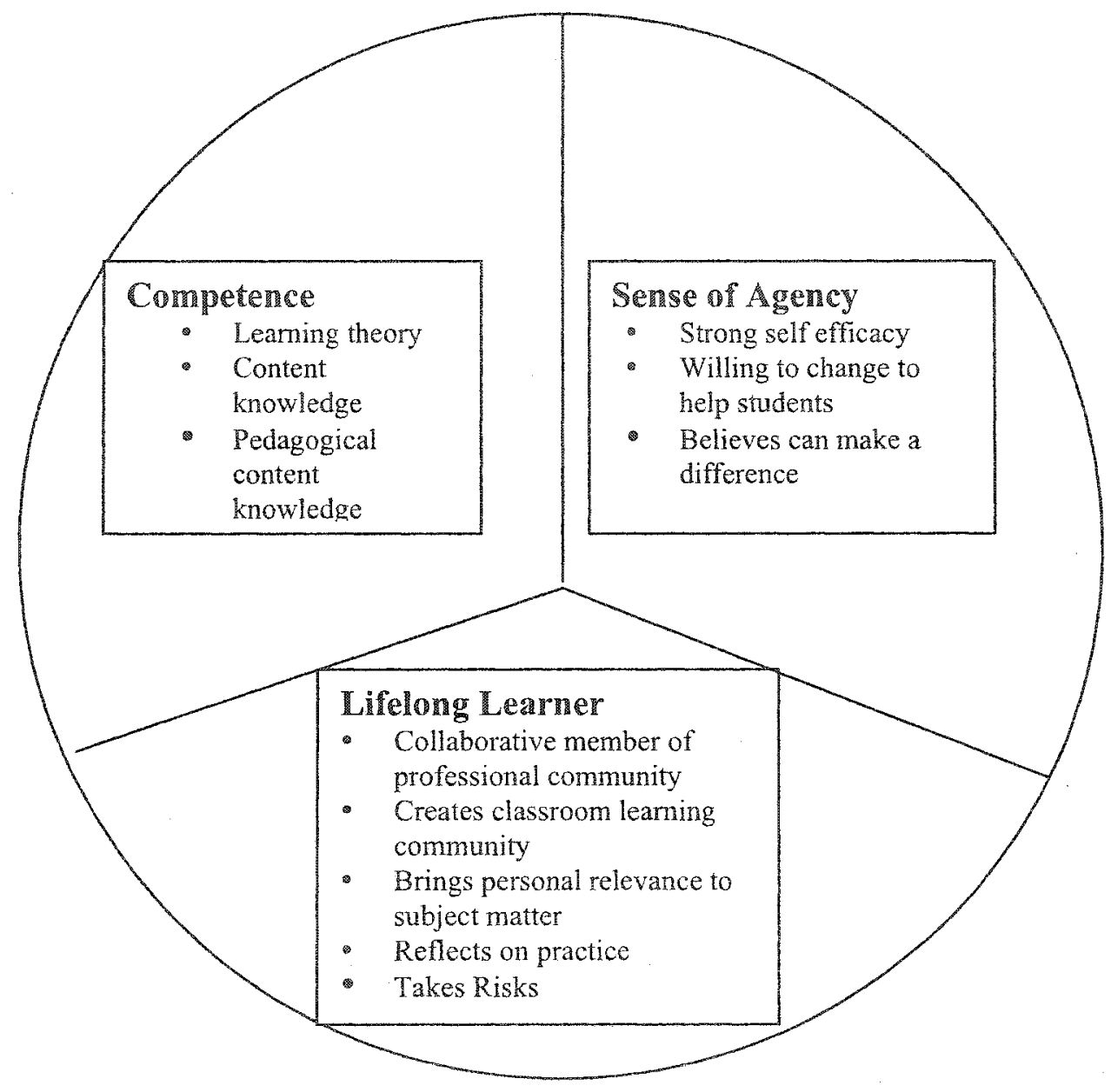

\section{Educational Reform.}

For the purpose of this study, educational reform is defined as a move toward a more progressive agenda, which involves adopting a more student-centered social constructivist curriculum epitomized by an experiential-based curriculum and authentic assessment. Schools moving toward a progressive reform agenda establish professional learning communities in which teachers are empowered to make school 
reform decisions based on what best meets the unique social and cultural needs of their students (Louis \& Marks, 1998).

Dewey (1990), a founding member of the progressive education movement at the turn of the 20 th century, believed in three important functions in education for democracy. First, education must be integrative, to prepare young people to be part of the society. Second, education must be egalitarian to work to be "the great equalizer" in America. Finally, Dewey argued that education needed to nurture the development of both the psychological and moral dimensions of the individual. He recognized that this was only possible within a democracy. Dewey held that educators needed to start with the child's natural curiosity and zest for knowledge and then bring the subject to the child through experiential learning and inquiry. Dewey challenged teachers to meet each individual child needs while simultaneously preparing the children to be socially responsible citizens within a democracy. He maintained that one starts with forming a connection with children as unique individuals and then make the learning relevant and meaningful to their lives. In progressive education, it was the teacher's job to place children into environments where they learn for themselves through personal experiences the reasons why equity and justice are important.

Hooks (1994) develops the premise of progressive educational reform a step further than Dewey. She advocates for "engaged pedagogy" in which individuals within the classroom feel honored, respected, and given voice. She describes a learning environment where both the students and the teacher feel empowered to grow and learn from each other and the subject at hand. In engaged pedagogy, students 
engage in dialogue, bring their unique perspectives into the classroom and together they gain a new more inclusive knowledge of the world. Hooks asserts that the classroom learning community should be "... a place where differences could be acknowledged, where we would finally all understand, accept, and affirm that our ways of knowing are forged in history and relationship of power" (p. 30). Progressive educational reformers work to develop emotionally safe, respectful communities within classrooms. Delpit (1995) states, "We must keep the perspective that people are experts on their own lives" (p. 47). Connections, respect, honoring of the diversity within America' pluralist culture remain essential elements of the progressive educational reform agenda.

Progressive educational reform strives toward a goal of equity, justice, and respect for all the nation's children. Delpit (1995) finds that to do that teachers must first learn how to listen deeply, in order to really know one's students:

If we are to successfully educate all of our children, we must work to remove the blinders built of stereotypes, monocultural instructional methodologies, ignorance, social distance, biases research, and racism. We must work to destroy those blinders so that it is possible to really see, to really know the students we must teach. Yes, if we are to be successful at educating diverse children, we must accomplish the Herculean feat of developing this clearsightedness, for in the words of wonderful Native Alaskan educators: "In order to teach you, I must know you." (pp. 182-183)

Ayers (2000) reinforces Delpit as to the importance of caring and respecting one's students deeply:

An engaged teacher begins with a belief that each student is unique, each the one and only who will ever trod the earth, each worthy of a certain reverence. Regard extends, importantly, to an 
insistence that students have access to the tools with which to negotiate and transform the world. (p. 2)

Progressive educational reform works to empower students. Ayers (2000) explains that the teacher's role is to invite students to be, "More capable, more thoughtful, and powerful in their choices, more engaged in a culture and a civilization, able to participate, to embrace, and yes, to change all that is before them" (p. 3). Ayers advocates for progressive reform that empowers students through establishing an environment, "Abundant with opportunities to practice justice, to display, foster, embody, expect, demand, nurture, allow, model, and enact inquiry toward moral action" (p. 2). Teachers-as-change_agents have the tools to move toward progressive educational reform that will empower their students to be viable members of the United States' $21^{\text {st }}$ century democracy.

In addition to preparing students for political action in a democracy, progressive education reformers advocate that a place for joy be integrated into the learning process. Delpit (1995) identifies the essence of progressive educational reform:

We need to bring to our schools experiences that are so full of the wonder of life, so full of connectedness, so embedded in the context of our communities, so brilliant in the insights that we develop and the analyses that we devise, that all of us, teachers, and students alike, can learn to live lives that leave us truly satisfied. (p. 104)

Teachers-as-change-agents work to establish learning communities for their students that are full of the wonder as described by Delpit.

The term educational reform is one of the most controversial, complex, and 
least understood terms in the study. Some of the recent educational reforms move education toward standardization and advocate for a tightly structured cultural transmission of a set American canon of knowledge in which accountability is measured through standardized testing of "generic body of information." Typically these types of reforms are mandated externally without regard to the specific needs of the students and without input from the actual individual school's teachers who are required to implement them (Merrow, 2001; Sikes, 1992).

Schools are pulled in both directions, toward providing a progressive education agenda that serves the needs of their diverse student population and toward reforms that revolve around federally mandated standardization that strip away teachers' ability to make their own professional judgments about what is best for their students. This study identifies ways in which a teacher education program prepared teachers as change agents who have the tools to continue work toward student-centered progressive educational reform despite the current federal pressure to move in another direction. This definition of educational reform better matches the philosophical mission and goals of the program under study.

\section{Significance of the Study}

Determining a teacher education program's ability to develop teachers-aschange-agents is relevant on both a local and national level. In response to the failure of the current educational system to provide equitable quality education for all children, schools nationwide are in the process of yet another wave of educational reforms (Cotton, 2001). Schools are under tremendous pressure to become more 
effective learning communities that "leave no child behind." However, convincing evidence exists that without teachers' ownership of an educational reform, the process will not succed. Given the current crisis in public education, fostering teacher change agents is an urgent undertaking, worthy of serious consideration. Fullan, Galluzzo, Morris, and Watson (1998) concluded their report on teacher education reform with this urgent note:

We are dealing with a reform proposition so profound that the teaching profession itself, along with the culture of schools and schools of education, will have to undergo total transformation in order for substantial progress to be made- that the agenda is much, much deeper than many realize. Included in this transformation is the growing realization that the walls of the school are tumbling down, requiring teacher and principals to radically reform their relationship to parents and the community, governments, technology, the corporate sector, and the teaching profession as a whole. (p. 68)

Teacher education programs need to be prepared for this transformation. The National Commission on Teaching and America's Future (NCTAF,1996) predicted 2 million new teachers would enter the profession in the next decade. Schools of education need to know if they are preparing the next generation of teachers to respond to the significantly different requirements of the $21^{\text {st }}$ century educational landscape. 


\section{CHAPTER II}

\section{LITERATURE REVIEW}

In order to explore the proposed research questions three different but related areas of educational research need thorough consideration. First, the research on educational change is explored. Second, the research on the relationship between teacher preparation, and school change is examined. Finally, the research on teacher education program evaluation is reviewed to determine the most appropriate evaluation tool to measure the program.

Educational Change and the Role of the Teacher

The literature on educational change identified a number of factors that influence the change process within American public schools. The most significant barriers to change are the strong cultural norms within schools that block risk taking, collaborative learning, and teacher empowerment. Cultural barriers make educational change a difficult process. In contrast, the research on successful educational change reveals some essential elements to successful restructuring efforts.

Advocating for school change is not a new phenomenon. One hundred years ago Dewey attempted to change schools to be more child-centered with integrated thematic curricula. In subsequent decades, various educational reforms were 
presented as the next savior for education. However, these reforms failed repeatedly. Despite radical societal changes, the American educational system changed very little over the last 100 years. Through examination of many wellintended educational reforms, researchers concluded that changing the school's structure without substantially changing teachers' classroom practice does not result in the desired effect of the initial reform effort (Elmore, 1995). Gregorian, president of Camegie Corporation, aptly stated, "Within the school reform movement, reform of the teaching profession must occupy the central role" (cited in Hinds, 2002, p. 2). Teachers must have ownership of the reform for successful implementation to take place (Marks \& Louis, 1997).

Even within the nation's leading schools, Hatch (2000) identified some barriers holding schools back from making the changes necessary to reach all children. Hatch analyzed evaluation data from the New American Schools Development Corporation (NASDC), established by the first Bush administration in 1991. NASDC's role was to raise private huds to "jumpstart" the creation of innovative new schools. Six hundred design teams applied for money for systemic change proposals. NASDC funded 11 different design teams to develop "a new generation of American schools" (p. 561). Hatch examined both the extensive evaluations written by the NASDC and the annual report from the schools involved. He found little evidence that directly linked the changes to any positive outcome. In fact, Hatch concluded that the more extensive the changes the NASDC design teams attempted the less likely they were to succeed. Hatch used business organizational theory to explain why he believed a less radical, 
more balanced approach might have been more successful. He noted that the more innovative the changes, the more time required for teachers and communities to accept the necessary adjustments in their teaching and approach to education. Hatch observed that the public appeared unwilling to wait while a school moved through the inevitable challenges inherent in the different stages of organizational change.

Schein (1985) studied the stages of organizations and the dynamics of change. He explained that human systems move between stages of equilibrium and disequilibrium. In order for organizational change to take place, he argued that reformers must recognize those stages and work with them. For organizations to learn, grow, and change, or to "unfreeze" as Schein called the change process, the participants must feel "psychologically safe." Hatch (2000) suggested that the psychological safety necessary for schools to participate in major educational change was absent, even in the innovative schools he examined.

Little (1982) conducted a groundbreaking study of six urban desegregated schools. Using semi-structured interviews with 105 teachers and 14 administrators along with extensive observations, Little identified important patterns in schools where successful implemented change was taking place. Little's research confirmed Schein's statement that schools must be safe places for taking risks, where a norm of learning is in place for successful educational reform:

Staff development appears to have greatest prospect for influence where there is a prevailing norm of analysis, evaluation, and experimentation ... By celebrating the place of norms of collegiality and experimentation, we place the related matters of school improvement, receptivity to staff development, and 
instructionall leadership squarely in an analysis of organization setting: the school as workplace. (p. 339)

Elmore (1995) also investigated the development of school norms in restructured schools. He examined data from 24 restructured American schools, middle and high mostly urban schools: eight schools at each level from 22 different school districts. Data sources included teacher surveys, ratings of pedagogical quality, assessment of student academic performances, as well as some case studies that involved interviews and observations. Elmore concluded that restructuring was ineffective in raising pedagogical quality unless the shared norms within a school were changed first:

Reforms might focus first on changing norms, knowledge, and skills at the individual and organizational level before they focus on changing structure. That is teachers might actually learn to teach differently and develop shared expectations and beliefs about what good teaching is, and then invent the organizational structures that go with those shared skills, expectations and beliefs. (p. 26)

Sarason (2000) stressed the importance of structures for adult learning within schools. After more than 40 years of research about education reform, Sarason asserted in one of his most recent writings, "If contexts for productive learning do not exist for teachers, they can not create and sustain that context for students" (p. 198).

Louis and Marks (1998) studied the same 24 restructured schools in Elmore's study. They examined the concept of professional communities and identified some important qualifications related to their importance in educational reform. Louis and Marks concluded that the most effective changes happened when the professional communities revolved specifically around a focused analysis of educational practice. 
Schools that developed professional communities where teachers learned collaboratively showed more success.

For successful educational organizational change to occur, participants must feel ownership of the process (Elmore, 1995; Sikes, 1992; Spencer, 1996). Sikes (1992) examined more than 1,100 secondary teachers' perception and experiences working in 31 schools in Great Britain. She found that teachers were offended by imposed change, which they perceived as a criticism of the status quo and an implication of their inadequacy. This perception was particularly true of more experienced teachers, who felt their experience best qualified them to make professional decisions. Sikes stressed that teachers must be actively involved in the change process through a democratic approach in order to avoid low morale, dissatisfaction, and reduced commitment. Teachers needed to be given control over the process in order for change to be perceived as a positive experience.

Marks and Louis (1997) again examined the same qualitative and quantitative data from 24 restructured schools in the United States, but focused on the importance of teacher empowerment in the change process. They reported a complex message; teacher empowerment varied in its effectiveness to enhance student achievement depending on which dimension of teacher empowerment was examined. They concluded that schools where teachers were treated as competent professionals, who were empowered to make instructional decisions correlated with higher success at restructuring efforts. However, only when teachers were given power specifically 
over classroom practice and instructional decision-making was there a clear correlation with improvement for students.

Based on their careful examination of the history of educational reform, Tyack and Cuban (1995) also stressed the importance of educators taking ownership of future educational reform efforts. They emphasized that teacher ownership ought to be formed within collaborative groups:

Reforms should be designed to be hybridized, adapted by educators working together to take advantage of their knowledge of their own diverse students and communities and supporting each other in new ways of teaching. (p. 136)

Tyack and Cuban (1995) noted that when teachers were given the opportunity to adapt reforms to their unique school population, reforms were more relevant and ultimately more effective. Now, more than ever, teacher control of adapting curriculum to specific student needs is essential as public school classrooms become increasingly more diverse. "One size fits all" is no longer appropriate or acceptable.

Olsen and Kintman (2002) took a deeper look at the role of the individual teacher in the implementation of school reform than many of the other researchers. They identified seven interrelated influences that affect the degree in which a teacher chooses to invest in any given reform within their school community. They conducted an extensive study of 36 California restructured schools. Using observations, documentation, and interviews, they found that an individual teacher's personal experience, level of expertise, assumptions about leaming, the place on the career cycle, personal relationships with other staff members, personal interests and the stage at which they became involved in a reform effort all have major mediating influences 
on a teacher's level of involvement in an educational reform. Although they acknowledge that a teacher's background will influence a teacher's openness to change, Olsen and Kirtman never looked at the preservice training of the teachers involved.

When Clandinin and Connelly (1995) conducted a follow-up study of some of the graduates of their teacher education program, they were able to identify times when new teachers' sense of agency and passion were challenged within their new school contexts. One of their graduates stated, "Situations that tear at the heart of my practice are the ones in which I am stripped of voice and agency" (p. 24). At the same time, the authors also found "safe havens" for teachers where "educators are vibrantly present, where their voices are unconditionally heard, where their relationships are authentic and secure" (p. 140). Clandinin and Connelly called these safe havens "knowledge communities," places where teachers gathered where their "personal practical knowledge" would be recognized and valued. Importantly, Clandinin and Connelly emphasized these knowledge communities were essential elements in the implementation of educational reform:

They are seeding grounds for competing stories, stores that may lead to educational change. Knowledge communities promote this kind of growth. They are important during times of transition...bridges between theory and practice...Knowledge communities emerge and grow as teachers come together in their professional knowledge landscapes. (p. 141)

Clandinin and Connelly argued that imposed educational reforms failed when teachers were not given a forum, a knowledge community, in which they could process through the changes in a way that was respectful and validated their professional knowledge: 
The main reason given for this ineffectiveness of school reform mandated by those in the conduit is that teachers divert the plans... from teachers' perspective- when they refuse to adopt reforms imposed on them.. rising up to take charge of their moral professional landscape...teachers express human desires in opposition to the imposed moral horizons established by the conduit. (pp. 162-163)

Teachers will resist reforms imposed on them when they feel the changes violates their personal moral judgment.

In summary, the research on educational reform is extensive. Although schools are difficult institutions to change, some clear patterns have emerged in the research on successful educational change. Researchers reported that schools need to establish shared norms of collegiality in which school-based professional communities focus on student achievement. Teachers within these professional communities must be regarded as competent professionals and be empowered to work together for the good of their students. This research examined whether the inclusion of professional communities, tools for empowerment, reflection, and analysis within a teacher preparation program can foster the later establishment of a school environment that will facilitate effective educational reform.

\section{Teacher Education and School Change}

Researchers questioned the relationship of teacher preparation programs to the development of more effective schools. O'Hair and Odell (1995) advocated that teacher education programs have a role in preparing change agents for our schools:

Change is on the agenda for schools, and teachers need to be key actors in helping define and shape that change... teacher educators are challenged to renew and broaden teacher education programs 
to include a strong emphasis on proactive teacher leadership roles in schools. (p. xxiii)

They argued that teacher education programs need to take a leadership role in facilitating school change. Fullan and Hargreaves (1992) agreed, "Teacher development is tantamount to transforming educational institutions" (p. 6). If universities are not preparing new teachers to come into schools ready to make change, then the job of school reform will fail.

If the approach of a novice teacher's school does not match the approach he or she learned in the teacher education program, the teacher is caught in a bind. A novice teacher will have difficulty putting new theory into practice without guidance and support. In frustration, most novice teachers relinquish new ideas and revert to the status quo (Hargreaves \& Jacka, 1995; Hoy \& Rees, 1977).

For example, Hoy and Rees (1977) used a series of scales to determine the influence of field experience on changing the idealism of novice teachers in terms of classroom control. They hypothesized that preservice teachers would become more authoritarian as a result of student teaching. They collected data from 112 secondary seniors before and after student teaching. Their findings showed an increase in bureaucratic orientation after student teaching. They concluded that schools of education do a disservice when they advocate change without providing the "sociopsychological tools necessary for effective implementation of such orientation" (p. 25). Hoy and Rees also suggested that without changing the schools, teacher education programs "in general seem limited to a modicum of success at best" (p. 25). 
They raised some important questions as to the ability of teacher preparation to have any lasting impact on educational reform.

Hargreaves and Jacka (1995) also raised some concems about the possible lack of influence of teacher preparation programs on novice teachers' ability to sustain idealism after entering the work force. Hargreaves and Jacka took a completely different approach to their study. They conducted an in depth case study of one first year teacher during her first five months teaching. Hargreaves and Jacka followed the novice teacher's frustration and increasing sense of defeat. Faced with a difficult teaching environment, the teacher ultimately gave up each area of her idealism and moved into survival mode. In this case, Hargreaves and Jacka argued that exemplary student teaching placements in professional development schools can "seduce" novice teachers with a false sense of the reality of teaching. They concluded:

As long as new teachers entering their first positions have to confront conditions of physical isolation, teacher cultures of noninterference and individualism, absence of administrative or collegial support, and school staffs who are unreceptive to the new methods that beginning teacher can bring, then no amount of tinkering with teacher preparation is likely to work. (p. 63)

In contrast to Hargreaves and Jacka's (1995) discouraging conclusions were the findings from a recent study at the University of California at Los Angeles (UCLA). Quartz and the TEP Research Group (2003) provided some important new insights into teacher preparation role in the development of teacher change agents. They looked at the impact of the first 5 years of UCLA's teacher preservice program in which there was "an explicit commitment to social justice" (p. 102). The UCLA program designers maintained that their preservice teachers learned as much, if not 
more about working for educational reform within inner city crisis schools from "enculturation into its critical, theory-rich leaming environment... than from specific teaching skills and techniques" (p. 102). Using extensive phone and email interviews with almost the entire pool of graduates, the researchers identified some key components in their program that sustained their graduates in the face of difficult teaching situations. First, preservice teachers were guided in the development of an asset model approach when working with poverty level communities versus a more conventional deficit model. The ability of preservice teachers to see community assets within poverty level neighborhoods appeared to be an important factor in graduates to sustain their convictions once working out in the field. They did not blame their students and families for their situation, instead UCLA graduates sought out assets in the community to build and strengthen their teaching environments. Graduates were able to identify the importance of relationships between the university and the communities. Since preservice teachers in the UCLA program were expected to join a community group and become involved actively in local issues, this engagement continued when graduates were out in the schools. Second, the data also indicated that graduates had a strong sense of efficacy, with $86 \%$ reporting that they believed they were making their schools and communities a "more just or caring place" (p. 107). Also, graduates believed that part of their teaching role was to ensure that students and parents' voices were heard. A third factor that appeared to be crucial in sustaining graduates' commitment to social justice and urban educational reform was the maintenance of a professional learning community. A number of ongoing teacher 
networks both online and in person, prevented novice teachers from feeling isolated and unsupported in the face of the difficult challenges while working in urban crisis schools.

The UCLA researchers examined a research question similar to the one that guides this research study. However, a significant difference exists. The UCLA program accepted only those who were already committed to a social justice agenda. The commitment to social justice was nurtured throughout the length of the program. In the current study, commitment to social justice is not a prerequisite for admission into the program. The question as to whether it is possible for a program can accept preservice teachers who do not necessarily come into a teacher preparation program intending to be change agents and still develop the attributes of teacher change agents within the confines of a four-quarter graduate school program.

The relationship between teacher education programs and school change has been discussed in numerous reports. With regard to teacher education research, Cochran-Smith (2001) pointed out, "There has not been complete consensus in teacher education at any point over the last half century - nor is there now, about which questions are the right ones to ask" (p. 4). Scant research has looked specifically at how teacher education programs play a part in the development of teachers who are open to change. However, researchers have considered elements of each of the three dimensions of the construct of teacher-as-change-agent. As stated in the operational definitions, the three dimensions of the construct of teacher-as-change-agent are: 
(a) teacher competence, (b) teacher-as-learners, and (c) a teacher's sense of agency.

The next three sections look at the research on each of the three components of the construct of teacher-as-change-agent and its possible development with a teacher education program.

\section{Teacher Competence}

Cremin (1961) in his comprehensive study of the demise of the progressive movement argued that progressive educational reform requires "infinitely skilled teachers." The 1996 publication of What Matters Most: Teaching for America's Future by the National Commission on Teaching and America's Future (NCTAF) has influenced the current focus on teacher quality. The commission's chair, former North Carolina Governor Hunt, asserted:

The reform movement of the last decade cannot succeed unless it attends to the improvement of teaching. If we pay attention to supporting knowledgeable teachers who work in productive schools, American education need suffer through no more deadend reforms. (p. 7 )

The NCTAF Executive Director, Darling-Hammond, has "been explicit and tireless in getting the word out about the central message of the report: what teachers know and can do is the single most important influence on how and what students learn" (Cochran-Smith, 2001, p. 4). Teacher competence is the most widely studied of the three dimensions of teacher-as-change agent.

Researchers have clearly documented the crucial role teacher effectiveness has on students' ultimate achievement (Sanders \& Horn, 1994). In their landmark largescale study in Tennessee, Sanders and Hom compared achievement data across five 
subject areas for 60,000 third through fifth graders to demonstrate dramatic and devastating effects of multiple years of ineffective teaching on student achievement. Teacher effectiveness has an impact.

What is "effective" or "competent" teaching? Shulman (1987) divided teacher competence into seven different components. Later, Darling-Hammond (1997b) simplified Shulman's seven competences into three components, (a) subject matter competence, (b) pedagogical content knowledge, and (c) pedagogical leaming knowledge. Darling-Hammond's research demonstrated that a teacher must know more than just subject competence, but also needs to know how to effectively engage students with the material. In order to effectively teach in the multicultural classrooms of the 21 st century, Ladson-Billings (1994) and Nieto (2002) argued that teachers need far more than content knowledge. Ladson-Billings conducted a study of effective teachers of African American students. She found that effective teachers had a comprehensive knowledge and respect for students' cultural perspectives and knew how to make the subject matter relevant to their students' lives. Competent teachers also must know their students deeply, viewing the diversity of perspectives as an asset that enhances the education of all within the learning community. Cooper's (2003) case study of three white teachers deemed most effective by their African-American communities validated Ladson-Billings' earlier work. Cooper found that not only were the three white teachers competent in transmitting curriculum but they held a deep respect, empathy, and commitment for communities within which they worked. 
Hansen (1999) explored the concept of a teacher's understanding of students in detail. He called this understanding, "moral attentiveness ... a kind of precondition, or disposition, that makes possible giving sustained heed to students' academic learning" (p. 184). A teacher must know how to focus closely on "what students know, feel and think about the subject at hand, all with an eye toward their building both knowledge of the world and sense for how to continue learning about the world" (p. 176). Hansen maintained that teachers need to know their students at a deep level. Rosiek (2003) examined a related aspect to the development of teacher pedagogical content competence. Acknowledging the interrelationship between the learner's emotional and cognitive response to a subject, Rosiek explored the role of emotional scaffolding in teaching. He gave examples of how successful teachers through both explicit and implicit means guide students' emotional response to content. He argued that preservice teachers need explicit instruction in how to establish both cognitive and emotional scaffolding for the students within very specific context. Further, preservice teachers needed to learn skills in how to both examine the emotional needs of their specific students and then how to address those needs in order to insure student successful interaction with the content.

Clandinin and Connelly (1995) also explored the concept of a teacher's professional knowledge. They defined teachers' knowledge as, "that body of conviction and meanings, conscious or unconscious, that have arisen from experience (intimate, social, and traditional) and that are expressed in a person's practices" (p. 7). This is significant in regards to teacher education and the development of teacher 
knowledge, as preservice education has the potential to be a foundational experience in a teacher's development of his or her convictions and meanings about teaching.

Social constructivism incorporates both a deep understanding of the students and the subject matter. A teacher who uses social constructivism must have a deep understanding of the discourse of the subject matter in order to engage students in collaborative construction of understanding. Since social constructivism implies creating knowledge through collaboration, it is dependent on a teacher to facilitate classroom "discourse." Part of a teacher's knowledge base must be their ability to provide students with the tools for carrying on discourse within a specific discipline.

In Windschitl's (2002) theoretical analysis of the challenges for teachers who were attempting to use constructivist practices, he suggested that, "in addition to the need for teachers to understand how the various disciplines create knowledge, they must be familiar with how language is used within the disciplines as a tool for communication and negotiating ideas" (p. 147). Shulman (1987) observed:

Even in the most student-centered forms of education, where much of the initiative is in the hands of the students, there is little room for teacher ignorance. Teacher comprehension is even more critical for the inquiry-oriented classroom than for the didactic alternative (p. 7).

Windschit outlined the complexity embedded in constructivist student centered pedagogy. Windschitl argued that in student-centered classrooms where problem solving, inquiry, or design tasks are taking place, "Teachers must not only be familiar with the principles underlying a topic of study but also be prepared for the variety of 
ways in which these principles can be explored by learners" (p. 147). The type of a sophisticated level of competence required to effectively implement social constructivist teaching strategies requires extensive training and support.

Teacher education reform has focused primarily on ways to ensure new teachers' professional competence. Over the last decade, a rapid proliferation of new standards and accreditation procedures for teachers and teacher education programs emerged. Institutions accredited by the National Council Accreditation of Teacher Education (NCATE) exist in 40 states and produce more than two thirds of the teachers. Despite the lack of correlation between teacher testing and effective teaching, preservice teacher testing has become a primary tool for measuring teacher competence. Ironically, Cochran-Smith (2001) reported, "There is little evidence that teacher test scores are related to actual teaching performance in classrooms or to students' learning" (p. 11).

A number of studies attempted to identify the determinants of teacher competence. In fact, Cotton (2001) identified more than 150 different variables that constitute teacher competence. The lack of consensus as to what constitutes teacher competence makes it difficult to evaluate. D'Costa (1995) discussed the complexity of creating teacher evaluation tools:

The development of a teacher assessment program is challenging. Much depends upon how well the practice-relevant model of competence is defined. A primary problem in teacher assessment is the complexity of the teaching role. This makes the domain of the assessment difficult to define and translate into required skills. (p. 291) 
Most of the recent research around teacher competence revolves around the value, or lack of value of attending a teacher licensure program versus possession of a subject area degree.

Some of Darling-Hammond's (1997a) research compared teachers who attended licensure programs in established teacher education programs versus teachers who were uncertified. Her research indicated increased student achievement when teachers had competence in both subject matter and pedagogy.

Goldhaber and Brewer's (1999) controversial study has been used to argue both sides of the teacher credentialing debate (Darling-Hammond, 2002; Walsh, 2001). Goldhaber and Brewer examined high school math and science teachers and compared student achievement test scores of students in classes taught by certified and non-certified teachers and those with and without degrees in science and math.

However, Goldhaber and Brewer may have contradicted their initial argument in the conclusions. For instance, they asserted:

...We find that the type of certification a teacher holds is an important determinant of student outcomes. In mathematics, we find teachers who have a standard certification have a statistically significant positive impact on student test scores relative to teachers who either are not certified or certified out of subject. ( $p$. 94)

Later in the same report they concluded, "Contrary to conventional wisdom, mathematics and science students who have teachers with emergency credential do no worse than students whose teachers have standard teaching credential, all else being equal" (p. 97). These contradictions left Goldhaber and Brewer's study open to interpretation by each side of the certification battle. 
Ferguson's (1991) longitudinal study in Texas has also been manipulated to argue different points in the controversy over what constitutes teacher competence. Ferguson used data from the Texas Examination of Current Administrators and Teachers (TECAT) that was administered in 1986 to compare teachers' scores on language skills test to student achievement and student dropout rates. Using 1980 census data Ferguson was able to factor in a wide number of variables including: socio-economic background of the student, race of student and teacher, class size, level of teacher's education, years of teacher experience, and rural versus suburban, urban schools and Mexican border communities. He examined the same student cohort test scores in third, fifth, ninth, and 11 th graders. Nine hundred school districts were included in the study. Ferguson found that:

Teachers matter ... Controlling for all of the influences discussed above, all four of the variables in the analysis that measure teacher characteristics (TECAT scores, class size, experience, master's degrees) have statistically significant effects on student test scores. (p. 7)

Given that the teachers' scores on language skills tests were one of the variables found to be very significant, the advisors to the United States Department of Education has cited this study as a rationale for measuring the quality teachers based on a teacher's language skills and not on participation in a teacher preparation program (Walsh, 2001). At the same time proponents of teacher preparation programs have also cited Ferguson's study as a rationale for maintaining and enhancing teacher education (Darling-Hammond, 1997a). Each group focuses on different aspects of the study's findings. The advocates for reducing teacher preparation programs focus on 
the importance of a teacher's verbal skills. However advocates of more extensive teacher preparation cite Ferguson's findings that teacher experience was the most important determinant of the highest student test scores, lowest dropout rates, and highest rates of taking the SAT. Since other studies have linked higher teacher retention to more thorough preparation, this study has been used to support the argument for comprehensive teacher preparation programs (National Commission on Teaching and America's Future, 1996).

Kornfeld, Marker, Ruddell, Cooke, and Fernlund (2003) conducted a self-study of their teacher education program. They were interested in determining the effectiveness of their preservice program in preparing teachers for "the reality of teaching" (p. 7). Teacher knowledge, they maintained, included a "dizzying array of facets, from content and pedagogical knowledge to an understanding of educational ends, purposes, and philosophical constructs" (p. 9). Furthermore, they noted that teacher knowledge is not static; it "continually evolves as they solve problems confronting them on a daily basis" (p. 9). In order to adequately determine the success of a preservice program, the authors argued that is necessary to look at graduates after they have taught for at least a year and have started to construct their own unique teacher knowledge base. Kornfeld and his colleagues conducted classroom observations and interviews with 18 randomly selected teachers who had graduated 3 to 5 years prior to the study. They found a clear disconnect between the theories presented during the preservice program and the actual practice observed. They noted that even when graduates claimed to be applying learning theories, the classroom 
observations revealed a lack of actual evidence of those theories in play. Instead, the new teachers, by in large, had learned how to "fit in" to their new school context. The study stimulated questions among the faculty as to how their preservice program could both prepare graduates "to fit in the system" and still "work as change agents at the same time" (p. 16). They concluded that preservice programs need to do a better job of discussing the politics of public schools and ways of coping within the system.

One hundred years ago, Dewey (1904) wrote extensively on the components of good teacher preparation. He advocated for strong subject matter competence along with deep analytic "inquiry" methodology:

Only a teacher thoroughly trained in the higher levels of intellectual method and who thus has constantly in his own mind a sense of what adequate and genuine intellectual activity means, will be likely, indeed, not in mere word, to respect the mental integrity of and force of children. (p. 161)

The current emphasis on teachers having strong content knowledge, specific pedagogical content knowledge, and a deep understanding of developmental needs of students is aligned with Dewey's perspective of what constitutes effective teaching.

No studies have clearly been able to demonstrate that content knowledge is sufficient for effective teaching (Haycock, 1998). Wilson, Floden, and Ferrini-Mundy (2001) conducted a meta-analysis of 300 studies of teacher preparation and found that, "There is little definitive research on the kinds or amount of subject matter preparation; much more research needs to be done before strong conclusions can be drawn" (p. i). Currently, most states rely on degrees in the subject matter, standardized test scores, and teacher licensure programs to ensure competence. 
Research has yet to be conducted that examines the value of specific components of a teacher licensure program to the development of teacher competence.

\section{Teacher as Learners}

Based on the findings on effective school change, the construct of teacher-aschange agents includes the component of teachers-as-leamers. A teacher-as-learner is comfortable with constant experimentation, reflection and analysis, as well as the transformative nature of social constructivist learning. Few studies have focused on teacher education programs' success in instilling the disposition to be lifelong learner in their program graduates. Dewey (1904) called for teacher education to prepare teachers to be ongoing "students of education" (p. 150). Sarason, Davidson, and Blatt (1986) identified flaws in teacher preparation, noting that many educational psychology courses focused on how students learn, but did not spend any time on how teachers learn. They argued, "The student in the process of becoming a teacher is not made acutely aware of how he is learning, to utilize himself as a source of understanding of the nature of the learning process" (p. 118). This is an important part of developing a teacher's role as a co-learner in the classroom community. The National Research Council conducted a comprehensive study of current principles of learning theory and its application to education (Bransford et al., 2000). The Council pointed out the lack of use of appropriate learning opportunities within teacher education programs, "Many approaches to teaching adults consistently violate principles for optimizing learning" (p. 26). They lamented that most teacher professional development programs were "not learner centered ... not knowledge 
centered ... not assessment centered ... and are not community centered" (p. 27).

The authors contended, "The principles of learning and their implications for designing leaming environments apply equally to child and adult leamers" (p. 27). While in the teacher education program, prospective teachers must not only be told how to teach others, but also that they must take on the role of continual leamers (Danielewicz, 2001; Dewey, 1904; Nemser, 1983).

Preservice teachers must become cognizant of their role as self-learners. A key point to Hansen's (1999) analysis of a teacher's developing understanding of students is their evolving understanding of one's own role as a teacher:

Open-mindedness, a willingness to change one's view, disciplining oneself to keep focusing on students' learning these terms describe the teacher's own evolving character as a person... What begins as an attempt to understand students becomes at the same time, a potentially career-long process of the intellectual and moral education of teachers themselves. Understanding students becomes not a means to an end, but an end in its own right, worthy of teachers' very best efforts. (p. 184)

During the preservice experience, teachers need opportunities to be flexible thinkers, so they will be able to adapt their perspectives on the relationship between teaching and learning while striving to understand their future students.

Danielewicz (2001) concluded that teacher education programs must establish the same elements essential for young students' learning within the preservice program design. How to teach effectively, as a co-leamer must be modeled, not just presented in the abstract. Danielewicz found that preservice teachers needed to be placed in situations that challenged their current schema on teaching. 
According to various teacher education advocates, preservice programs must incorporate the practice of deep reflection. The Holmes Group (1986) stated, "The improvement of teacher education depends on the continuing development of systematic knowledge and reflective practice" (p. 66). Through reflection, a teacher becomes stronger, someone who has a sense of what needs to be done next. Dewey (1904) and Danielewicz (2001) suggested that reflective practice involves having the opportunity to reflect back on one's ingrained beliefs about learning that have developed over the accumulated years of experiences as a student over a lifetime.

Danielewicz (2001) conducted a multiple case study of graduates of her own preservice teacher program. She studied the development of novice teachers' evolution as professional educators. She saw reflective practice as a key element of that process. Danielewicz maintained that reflection should involve:

A person's active analysis of past situations, events, products, with the inherent goals of critique and revision for the explicit purpose of achieving an understanding that can lead to change in thought or behavior. (p. 156)

Goodlad (1994) elaborated on this concept:

The mission is not just to prepare teachers for the mechanics of their occupation, although this too must be done, but to develop in them the intellectual habits of reflection on their calling and daily work that are the mark of a professional community engaged in self-improvement. (p. 38)

Proefriedt (1994) agreed with Goodlad, when he stated during teacher education programs reflection must be instilled:

A commitment to a lifetime of sustained reflection with other teachers on the work at hand. At the heart of that reflective effort 
are an inquiry into questions of educational purposes and an effort to align what and how we teach with those purposes. (p. 18)

Preservice teacher reflection should be a core practice within a teacher preparation program, a practice so deeply ingrained that it will be sustained throughout a teacher's career.

Zeichner and Liston (1987) examined the teaching of reflective practice in their teacher education program. Citing Dewey, they noted, "The central aim of education is for students to become competent inquirers, capable of reflecting on, and critically examining their everyday world and involved in a continual reconstruction of their experience" (Liston \& Zeichner, 1991, p. 48). Despite this clear goal, Zeichner and Liston (1987) found mixed results in their own teacher preparation program's ability to successfully lead preservice teacher to inquiry and reflection on classroom practices during student teaching. At the time of the study the University of Wisconsin program did not follow a cohort model. Different faculty taught each segment of the program. Zeichner and Liston speculated that the lack of a coherence and well-coordinated effort across the whole program might have been partially responsible for the lack of deep reflection evident during student teaching. They Suggested that inquiry and reflection might not become apparent until farther along in a teacher's career and that a longitudinal study might be helpful to see if reflection becomes visible after a few years of teaching experience. Finally, they lamented that the schools where new teachers enter need to be places where inquiry and reflection are sanctioned and honored, "before inquiry-oriented teacher education programs will have a chance of making any lasting impact" (p. 44). 
Weiss and Weiss (2001) also studied their teacher preparation program's ability to develop reflective practice in their preservice teachers. They maintained that, "Reflection can be an agent for informing, challenging, and transforming the norms of professional practice" (p.126). If teachers are to be "competent inquirers," and open to change, then teacher education programs must provide them with opportunities to continually reflect and reconstruct their practice. Similar to Zeichner and Liston, Weiss and Weiss stressed the need to conduct studies that follow up student teachers once they are teaching in their own classrooms to determine if teachers are able to sustain reflective practice.

In her study of reflective practice in preservice teachers, Davis (2000) concurred with Zeichner and Liston's study that non-reflective preservice teachers did not develop skills that were more reflective as a consequence of university coursework. However, she found that those students who came into a teacher preparation program with an inclination toward reflection showed growth in their reflection skills.

Dinkelman (2003) conducted an action research/case study into the question of the development of critically reflective teaching within his own social studies methods course and student teaching seminar. He defined self-study as "intentional and systematic inquiry into one's own practice" (p. 8). Dinkelman argued that, "experience teaches nothing to the non-reflective practitioner" (p. 9). Through the process of self-study, Dinkelman examined the impact of his explicit reflective practice on his preservice teachers, as well as his own practice. He concluded that 
self-study and reflective practice on the part of teacher educators themselves were essential components of effective teacher education.

Leading new teachers to see the value of reflective approaches to teaching involves something more than merely adding the right experiences and techniques to a teacher education curriculum. Rather, self-study requires a reconceptualization of the process of teacher education itself. (p. 16)

Reflective analysis of teaching and learning takes place within a collaborative process with the teacher educator modeling and explicitly guiding the process.

Part of what preservice teachers must learn is how to socially construct their knowledge of teaching and learning. If preservice teachers are provided with opportunities to participate in social constructivist leaming environments, teacher educators might assume that the preservice teachers would provide similar experiences for their own students. However, a number of studies showed that this transfer has not always occurred as intended (Mintrop, 2001; More, 2003).

More (2003) studied 77 preservice teachers out in their field experiences who had been exposed to constructivist methods in their teacher education course work. More used data gathered from observations, journal entries, interviews, as well as surveys of both the preservice teacher and their mentor teachers. She found "almost without exception, procedural concems of time management, lesson planning, and classroom management" were the primary focus of novice teachers. The message preservice teachers were getting in the field is exemplified by this mentor teacher's advice, "Forget the theory stuff you learned in your methods courses- that's not the real world...that's not real teaching" (p. 31). 
Mintrop's (2001) 3 year study of his teacher education program's attempt to teach preservice teachers constructivist methods through a constructivist-oriented seminar had similar dismal results. Mintrop concluded the study with words of hope.

Despite the failure of the seminar to advance the use of constructive instructional practices among his preservice teachers, Mintrop stated:

It was a success in that we as teacher educators and researchers learned from it to tailor realistic expectations and to embrace the multiple facets, tensions, and dilemmas that the construction of knowledge entails for teachers and teacher educators. It is up to other teacher educators to learn from our mistakes and find a better way, perhaps to get it all done. (p. 236)

Constructivism is so complex and foreign to how most preservice teachers were instructed as students that they are frequently not able to make the leap from a theory to actual practice as beginning teachers (Korthagen \& Kessels, 1999; More, 2003; Windschitl, 2002). In their study of a Dutch teacher education program, Korthagen and Kessels (1999) found similar difficulties in preservice teachers' ability to make the transfer from theory to practice. However, they showed that when practice comes first and then theory is applied in a more integrated framework, preservice teachers were able to develop schema in which they could construct meaning through "phronesis" which they defined as:

Situation -specific and related to the context in which they meet a problem or develop a need or concern, knowledge that bring their already existing, subjective perception of personal relevant classroom situation one step further. (p. 7)

Korthagen and Kessels (1999) concluded that preservice teachers need multiple opportunities to learn within context, reflect with their mentors, and continually 
practice until it becomes part of their being as professionals. Using Vygotsky's social constructivist theory as a guide, Korthagen and Kessels demonstrated the effectiveness of scaffolding integration of theory and practice. As quoted by Wink and Putney (2002), Vygotsky explained the importance of social interaction in the learning process:

Language informs thought, and thoughts come to life in language. Meaning springs from the union of verbal thought. Thus is the education process an active one on three levels: the student is active, the teacher is active, and the environment created between them is an active one. (p. 39)

Meaning is created within a social context. Caine and Caine's (1997) case study of two schools engaged in reform and professional development validated Vygotsky's theories, "Part of our identity depends on establishing community and finding ways to belong. Learning therefore is profoundly influenced by the nature of the social relationships within which people find themselves" (pp.104-105). Danielewicz (2001) concurred, "As individuals, we use language to represent thought and to make meaning, but language is not an individual's universe since it exists exclusively in a social context. Its form is derived through interaction between individuals" (p. 22).

Kluth and Straut (2003) studied the effects of modeling collaborative teaching within a preservice program. As special education and general education professors, they chose to design and co-teach their courses based on the assumption that "by providing a collaborative model for students, they would be better prepared to function in progressive and diverse classrooms on their graduation from our program" (p. 230). Their preliminary findings from class evaluations were positive. However, they have 
no evidence that the practices they modeled will carry over into their graduates' practice. Kluth and Straut were unable to find previous studies that looked at this relationship and advocated for research to explore "how co-teaching and collaboration in the college classroom affects student behaviors, actions, and decision in the field" (p. 238). Arguing the today's diverse schools necessitate collaboration, the authors strongly recommended that preservice teachers learn collaborative skills (p. 238).

In summary, teacher educators advocate for the development of lifelong leamers through a social constructivist teaching model and reflective practice. However, the studies found that beginning teachers have a hard time moving beyond the theory of social constructivism to any kind of significant implementation in the classroom (Mintrop, 2001; More, 2003). Constructivism requires a major shift in teachers' experiential base in education, a change from teachers' own experiences as students and most likely a change for the students coming into their classrooms. It takes a lot of support and confidence to break a mold so early in one's career.

The role of teacher education in the development of the teacher as learner has been studied from various perspectives. Most of the research in the last 10 years was conducted by teacher educators conducting self-studies to determine their own program's ability to create reflective practitioners, or teachers ready to take the risks necessary to apply student-centered socially constructed instruction. The results have been mixed. The majority of researchers have expressed concerns about the complexities and challenges of moving novice teachers from theory to practice, 
particularly given the limited modeling in both preservice teachers' prior experiences as students and out in their field experiences.

The developmental nature of becoming a professional educator raises some questions in terms of setting realistic expectations as to the sophistication of a novice teacher's mastery of integration of theory and practice. Most of the studies look at teachers either right after student teaching or within the first year of teaching, before a teacher may be fully ready to integrate the complexities of teaching. Fessler's (1995) work on teacher career stages may offer some insights into the developmental nature of this dilemma and how a particular school's norms may influence that development. Fessler argued that the developmental process of teachers is not necessarily linear because the context within which teachers work will heavily influence the movement between developmental stages.

Few research studies in the past have focused on how teacher preparation programs have integrated collaboration, reflection, analysis, and risk taking inherent in the construct of teacher-as-change-agents. Research is limited that examines teachers a few years into their careers, when they are more ready to move beyond survival mode into more reflective innovative practices.

Teachers' Sense of Agency

Some teacher educators advocate for teacher education programs to provide a forum for developing novice teachers' sense of self-identity, voice, and authority. Research has not yet determined whether developing a sense of voice in preservice teachers will be sustainable once teachers are out in the field. However, a number of 
teacher educators have explored the role a sense of agency plays in effective teachers' lives. Hansen (1994) defined it as a "sense of vocation" explaining:

The sense of vocation implies a measure of determination, courage, and flexibility, qualities that are in tum buoyed by the disposition to regard teaching as something more than a job, to which one has something significant to offer. (p. 269)

In order to maintain this sense of vocation, teachers must have the freedom to make their own decisions about how to address their students' needs and problems. Hansen (1994) argued, "To take away that autonomy is to undermine the basic terms of their work" (p. 273). He advocated for preservice teachers to be given a forum to "begin articulating what the sense of teaching as a vocation entails before one actually takes charge of a classroom .... to test one's intuitions before proceeding" (p. 275). A teacher's sense of agency will continue to evolve throughout their career, but Hansen proposed it needed to be nurtured during the teacher preparation process.

Windschitl (2002) suggested that teacher autonomy can be threatening to political conservatives who advocate for controlled curriculum and standardized teaching, "Granting teachers the authority to create curriculum is often greeted with resistance from political conservatives who fear not only the teacher's autonomy in choosing content but also children's learning of critical thinking skills" (p. 154). Teachers must have the pedagogical tools in place that can help sustain their voices despite potentially politically difficult working conditions.

Danielewicz (2001) conducted follow-up interviews with graduates a year out in the field. She argued that novice teachers must have a sense of agency, a sense of obligation to change if the status quo is not working. Instilling the norm of 
collaboration can give new teachers the strength to resist the obstacles to fulfilling their dreams and can help sustain them when they are out in the field. Danielewicz asserted, "When teachers collaborate, using these strategies to work toward becoming the teachers they each envision, their power to resist the negative institutional forces that threaten to overwhelm is greatly enhanced" (p. 152). Quartz and the TEP Research Group's (2003) study of the UCLA program seemed to confirm Danielewicz findings. Quartz and the TEP group attributed the high retention rates of UCLA graduates teaching 5 years after completing their program at least partially to the sense of agency nurtured in the preservice program and maintained through collaborative support networks once graduates were out in the field.

Hammerness (2003) conducted a mixed method study of how new teachers' vision influenced their ability to stay hopeful in those difficult first years. She found that new teachers who had developed a realistic emergent vision were better able to hold on to their sense of hope. Their vision gave them purpose in the face of obstacles. Vision can enable a teacher to hold on to their sense of "efficacy - the teacher's sense that he or she is making a positive different in the lives of students" ( $p$. 52). Hammerness found that when preservice teachers' visions were made explicit during teacher preparation programs, teacher educators could guide preservice teachers through a process of examination. They could help in challenging and guiding the further articulation of novice teachers' beliefs. Teacher educators also could provide a forum for teacher educators to "assist new teachers to understand and deal with the gap between their hopes and their practice ... to navigate that gap ... to 
use their vision to select contexts in which they could sustain ... feelings of agency" (p. 52).

Fullan and Hargreaves (1992) argued that the development of a teacher's voice through the development of a professional community needed to start within a teacher preparation program. They proposed:

Teacher development must actively listen to and sponsor the teachers' voices, establish opportunities for teachers to confront the assumptions and beliefs underlying their practices' avoid faddism and blanket implementation of favoured new instructional strategies; and create a community of teachers who discuss and develop their purposes together, over time. Teachers need to feel that they are not alone in their sense of agency and passion for bettering the lives of their students. (p. 5)

Noddings (1986) has written extensively on the ethic of caring in education. She insisted that although caring must be central to teaching, one could not "produce caring teachers" through direct instruction in a teacher education program. Instead Noddings argued, "We approach our goal by living with those who we teach in a caring community, through modeling, dialogue, practice, and confirmation" (p. 502). Using Noddings' writings as a guide, Goldstein and Freedman (2003) looked at the complexity involved in a preservice program's attempt to develop caring teacher. Goldstein and Freedman were surprised to find that a conscious effort to develop caring teachers through the use of provocative thoughtful questions in electronic dialogue journals with 17 preservice teachers did not result in the level of sensitively and respect for their student's family that the researchers had assumed. After extensive qualitative analysis of the journal entries, they found their preservice teachers had not moved beyond a somewhat superficial perspective of what they 
perceived as caring. They concluded that regardiess of how carefully constructed a particular activity might be designed to establish caring teachers, the modeling of caring through the relationships between professors and their preservice teachers was the most important:

Caring teacher education resides in the relation between the professor and the students. We must remember that the nature of teaching "learning interactions experience by preservice teachers in their courses at the university level is of paramount important. (Goldstein \& Freedman, 2003, p. 452)

Liston and Zeichner (1991) also argued for the development of teacher advocacy and political voice within a teacher education program. They contended that time must be allocated in teacher education programs to study the social context of schooling so teachers can enter the workforce with adequate knowledge to advocate for change where it is needed. They reported that novice teachers should be "capable of acting in concert with other teachers and community members to alter significant societal or political dynamics" (p. 85). Moreover, Liston and Zeichner asserted that future teachers need to understand how the institutional and larger societal context aid or obstruct their chosen educational aims. For example, how does the fact that children spend more time viewing television and commercial programs than they spend in school impact a teacher's responsibility (Center for a New American Dream, 2000). Or how does the reality of Oregon's ranking as one of the worst states for hunger impact teacher's experience working in classrooms of hungry children (Oregon Food Bank, n.d.). Preservice teachers need to explore what it means to teach in a classroom of children who have not had enough to eat. This role of teacher 
preparation programs to develop teacher voice within a professional community is aligned with the findings on characteristics of successful restructured schools (Fullan \& Hargreaves, 1992).

In summary, many teacher educators have looked at specific components of the construct of teacher change agents, such as different aspects of teacher competence, reflective practice, and teacher voice. Although experts hold strong opinions on the subject, solid research demonstrating any long-term effects of incorporating all three components of the construct of teacher-as-change agent within a teacher preparation program had not yet been conducted.

Teacher Education Program Evaluation

Teacher educators do not have clear answers as to the most effective ways to prepare teachers for the complexities of 21 st century classrooms. Although teacher education programs have existed in this country for more than 150 years, historically program changes were not based on research. Repetitive pleas by Sarason and others for rigorous study of teacher education have their roots in 1962 with a controversial book entitled, The Preparation of Teachers: An Unstudied Problem in Education (Sarason et al., 1986). In their 1962 version, the authors argued that the research to determine the effectiveness of teacher preparation programs did not exist. Twentyfive years later, their revised version of the same book repeated the argument that very little research had been conducted to inform teacher educators about the effectiveness of the teacher education programs. Sarason contended that part of the problem stemmed from the division between teacher educators and researchers: 
As a group, educational researchers have nothing to do with the preparation of teachers. In regards to teacher training, they are incapable of seeing the gulf between theory and practice. Given their orientation, the preparation of teachers will remain unstudied. (Sarason, et al., 1986, p. xix).

Coladarci, an education professor at Stanford at the time of revised book's

publication, described in its preface the central thesis of this controversial text:

The contents and procedures of teacher education frequently have no demonstrable relevance to the actual teaching task... before the teacher educator rejects it out of hand, let him ask himself when his faculty last conducted an evaluation of the preservice program against the criterion of subsequent teaching performance in terms of variables that are definitive of the actual teaching situation. The answer is probably an embarrassing one. (Sarason et al., 1986, p. vii-ix)

At the turn of the $21^{\text {st }}$ century Wilson, Floden and Ferrini-Mundy (2001) reported a similar lack of rigorous research evaluating teacher preparation programs. Despite the existence of more than 1,300 teacher education programs in the United States as well as numerous alternative pathways to teacher preparation, Wilson et al. found little empirical evidence existed as to their effectiveness. They examined more than 300 published research reports on teacher preparation. The criteria for including a study in their analysis was four fold: (a) the study had to address their specific research questions revolving around the kinds of content knowledge, pedagogy and field experience required for adequate teacher preparation, (b) be published in a scientific journal, (c) be published in the last two decades, and (d) study United States teacher education specifically. Only 57 out of those 300 studies stood up to their criteria for inclusion in their research review. Despite the quantity of research identified, they concluded: 
The research base concerning teacher preparation is relatively thin. The studies we found, however suggest that good research can be done, but that it will take the development of more refined databases, measures, and methods, as well as complementary research designs that collect both qualitative and quantitative data. ( $p$. i)

Wilson et al. (2001) attributed some of the lack of evaluative studies of teacher education to the relative newness of the field of research. Echoing Sarason et al., they noted that teacher education evaluation research that examined "content, character, and impact of teacher education only began in the $1960 \mathrm{~s} "$ (p. 1). They also explained that very little federal govermment support remained for teacher preparation research. However, despite the lack of rigorous research, there was no lack of opinions. Wilson and his colleagues noted, "While the field does not lack exhortations about what teacher preparation should look like, there is much left to learn" (p. 1).

Until 1990, the vast majority of evaluative studies of teacher education programs were quantitative in nature, primarily in the form of follow-up surveys (Galluzzo \& Craig, 1990). Most of the studies of teacher education programs were either descriptive or correlational in nature. The literature on program evaluation included some analysis of the validity and usefulness of survey methods. Galluzzo and Craig expressed concern that although large quantities of survey data have been accumulated from a significant number of institutions, most of the findings lacked significance due to poor survey design.

Many of the most recent studies were designed to persuade an audience as to the merit, or lack thereof of traditional certification programs versus altemative pathways (Darling-Hammond, 2001; Feistritizer, 2002; Goldhaber \& Brewer, 1999; 
Raymond \& Fletcher, 2002). For example, Raymond and Fletcher studied teachers in Houston public schools, comparing the test scores of students in classrooms of teachers who went through the Teach for America (TFA) training versus student test scores from other Houston inner city classrooms. They concluded that students of TFA teachers were more successful on standardized tests than other Houston inner city students. However, Raymond and Fletcher's research has been refuted by another research study that examined the student achievement of students in Phoenix inner city schools taught by TFA versus cerified teachers in similar school settings (LaczkoKerr \& Berliner, 2002). Laczko-Kerr and Berliner argued that the Houston study was flawed because it failed to mention that the majority of Houston's inner city teachers were uncertified teachers with no training at all. Given the lack of Houston teachers' training, it was no surprise that the TFA teachers were better prepared. Lackzo-Kerr and Berliner carefully constructed their own study to compare TFA teachers only with teachers who graduated from standard teacher licensure programs. Their findings clearly showed that students of TFA teachers did not fare as well as certified teachers.

Feistritzer (2002) examined student achievement data from teachers who went through alternative teacher preparation programs, concluding that alternatively trained teachers were just as qualified as traditionally certified teacher. However, DarlingHammond (2002) argued Feistritzer's operational definition of "alternative certification programs" was misleading. According to Darling-Hammond, Feistritzer included all graduate level certification programs as "alternative." Data from comprehensive graduate level programs like the teacher education program under 
review were mixed into the pool with programs like TFA giving an inaccurate picture of what constitutes alternative pathways.

The National Center for Education Statistics (NCES,1999) studied a variety of programs to get a more comprehensive look at teacher preparation. NCES conducted a large-scale descriptive study of teacher quality. Surveying more than 4000 teachers across all regions of the United States, the researchers looked at teachers' perceptions of themselves in terms of preparedness in an array of teacher responsibilities. Significantly, less than half of the teachers surveyed felt "very well prepared" to meet the challenges of today (NCES, 1999 , p. iii). Only $41 \%$ of the teachers felt very well prepared to implement new teaching methods and $36 \%$ reported feeling very well prepared to implement state or district to curriculum and performance standards ( $\mathrm{p}$. 48). Will these teachers be ready and open to change their practice to better meet these needs? Although the study identified whether a teacher has completed a comprehensive licensure program, it did not examine the specific components of a teacher education program.

In the last decade, more qualitative forms of teacher education research were conducted. Case studies and self-study have become recognized for their contribution to the field because of their ability to probe deeply into the context specific nature of teaching and learning. Dinkelman (2003) defined self-study as "intentional and systematic inquiry into one's own practice" (p. 8). As Dinkelman noted, "The contemporary research is fueled by the growing acceptance of an important educational proposition - context counts" (p. 14). Zeichner (1999) in his review of 
"new scholarship" in teacher education identified self-study as "probably the single most significant development ever in the field of teacher education research" (p. 8).

Darling-Hammond (2001) argued that responsible research and policy agendas should:

...Aim to illuminate more fully specific aspects of teachers' knowledge and skills that make a difference for student learning and the ways in which the features of different teacher education models- how they organize the acquisition of content and teaching knowledge and build knowledge about practice as it is applied - are related to different teaching outcomes. (p. 71)

Darling-Hammond made the point that research is needed to help teacher educators identify the specific elements of a teacher education program that really make a difference in preparing teachers who will effectively reach students.

Wilson et al. (2001) recommended a similar direction for future teacher education studies that could measure specific components of a teacher preparation program. They also suggested that it would be strategically wise to conduct a series of local examinations of specific teacher education programs as well as some multi-site research, "These individual efforts can be assembled into more powerful and crosscutting approach to understanding teacher education" ( $p$. iv). They concluded their review of current teacher education program research:

The potential of research to lead the ongoing reform and improvement of teacher education in the United States is enormous. By building on what we have done, and by conducting rigorous studies of important questions, the research community can do its part to ensure that a well-qualified teacher is available for every child, in every classroom. (p. iv) 
Wayne and Youngs (2003) conducted a meta-analysis of studies looking at teacher quality and student achievement. Although they were not examining teacher education programs per say, they were trying to determine what teacher characteristics correspond to higher student achievement. They used the meta-analyses and reviews of Wilson, Floden, and Ferrini-Mundy and Darling-Hammond's work as well as an extensive electronic search in their attempt to find a relationship between specific teacher characteristics and student achievement. They restricted their examination to studies that compared student standardized test scores and teacher characteristics. They examined the research on teachers' college ratings, test scores, course taking, degrees, and certification status. They did find some positive correlations between a teacher's college's ratings and test scores. Except in math there has been very little correlation between high school students' test scores and teacher certification and course work. The study's authors acknowledged that results "would differ if graduation rates or future earnings were examined" (p. 107) or if the teacher characteristics of: experience, race, and teaching methods studied had also been factored in. They also noted that the makeup of the teacher population has been changing radically in the last three decades. Furthermore, Wayne and Youngs cautioned that effect size was not adequately considered in these studies. They noted, "Much remains open to policy makers' intuition" (p. 108). The differences between individual teachers with matching "characteristics" were far greater than when compared across the particular identified teacher trait. 
These missing links to the studies of teacher quality are significant. Based on the lack of conclusive evidence that teacher characteristics had a significant influence on student achievement, Wayne and Youngs (2003) recommended that hiring decisions should not "require particular qualifications" (p. 108). Wayne and Youngs concluded, "There are many important questions that remain unanswered" (p. 107). Ironically, despite their weakness, these studies influenced federal policy decisions defining "highly qualified teacher" and affected the hiring practices in all the nation's public schools.

A new exciting trend in teacher education is emerging (Cochran-Smith, 2003). Teachers for a New Era (TNE), primarily funded through the Carnegie Corporation of America, is an initiative dedicated to changing radically the way teacher education is assessed. TNE's first design principle is "Respect for evidence" (p. 188). Teacher education programs around the country are developing for the first time, "value-added tracking systems to assess the impact of program graduates on pupils' learning" ( $p$. 188). Project Delta, an initiative of the Carnegie Foundation for the Advancement of Teaching, is working with 12 universities to help develop collaborative efforts at program evaluation. Cochran-Smith saw these two initiatives as examples of a major shift in teacher education research:

Transforming teacher education into an enterprise that is grounded in research, revolves around continuous assessment of learning, and makes decisions driven by evidence is nothing short of a culture shift in our field. (p. 189

Rigorous research that evaluates teacher preparation programs is still in need. Teacher education program evaluation is coming into its own as a field of study. This 
research study contributes to the knowledge base that will inform teacher educators as to the most effective ways prepare future teachers.

\section{Literature Review Summary}

The research on successful school change clearly identified teacher collaboration, openness to continuous growth, learning, reflective analysis, and teacher voice as the essential components to successful implementation of school reform (Elmore, 1995; Little, 1982; Louis \& Marks, 1998). Numerous teacher educators have asserted that teacher preparation programs need to address teacher competence, teacher as life-long-learner including analysis, collaboration, and reflection, as well as the development of teacher advocacy. They argue persuasively that teacher education programs need to prepare teachers to have the potential to change the status quo of schools when it becomes clear that the school is not meeting student needs.

Recently, there has been a lot of research conducted in the area of teacher competency and teacher quality. The majority of these studies have been motivated by policy makers trying to determine the best policies for bringing quality teachers into the schools. Unfortunately some of the politically motivated research is contradictory and has been written to prove a particular point of view. There remains no consensus on the definition of teacher competence, nor consensus on how to determine the most appropriate means to achieve that competence (Cochran-Smith, 2001; D'Costa, 1995; Wilson et al., 2001).

Some teacher educators have studied their program's approach to teaching preservice teachers to be lifelong leamers. Specifically, aspects of reflective practice 
in preservice program have been examined, but few researchers have been able to find any long-term evidence of effectively instilling these traits in their program graduates (Danielewicz, 2001; Davis, 2000; Dinkelman, 2003; Weiss \& Weiss, 2001; Zeichner \& Liston, 1987). Other teacher educators have studied their program's effectiveness in preparing teachers to be collaborators who will model and teach social construction of knowledge (Kluth \& Straut, 2003; Mintrop, 2001; More, 2003). Researchers have not yet been able to find strong evidence of positive relationships between teacher education programs and the development of teachers as learners.

Researchers also studied the development of teacher voice and agency in preservice teachers (Danielewicz, 2001; Goldstein \& Freedman, 2003; Hammerness, 2003; Hansen, 1994; Nieto, 2003; Quartz \& TEP Research Group, 2003). Some of the researchers have been able to identify areas of success in creating a leaming community that nurtures a teacher's future sense of agency.

Teacher education program evaluation is a relatively new field of study. Traditionally teacher educators came into the field via the $\mathrm{K}-12$ classroom not from academia and therefore lacked a research orientation. In the last 20 years, political pressure to prove their worth has forced teacher educators to look more closely at their programs. Over the last decade teacher educators have begun to conduct rigorous research on their own practice and examine some of the specific aspects of teacher education programs. Though scholars seem to support the construct of a "teacher-as change agent," there does not appear to be adequate research as to the effectiveness of teacher education programs to develop teacher change agents. Accordingly, this 
research study offers some important insights as to teacher education programs' role in the development these attributes in future teachers. 


\section{CHAPTER II}

\section{METHODS}

The purpose of this descriptive study was to examine how one graduate teacher education program at a large urban university in the Pacific Northwest prepared teachers to be open to changing their practice and assisting their schools in moving beyond superficial reform to new ways of thinking. Researchers identified key components to successful implementation of school reform as: teacher collaboration, openness to continuous growth and learning, reflective analysis, and a teacher's sense of agency (Elmore, 1995; Fullan \& Hargreaves, 1992; Little, 1982; Louis \& Marks, 1998). This study offers insights to teacher education program designers on how to identify the most effective means to enhance the ability of new teachers to be strong agents of change.

\section{Review of Research Questions}

This research study was designed to answer the following question: What influence does a teacher education program have on the development of future teacher change agents? In order to answer this umbrella question, the following sub-questions were asked:

1. In what ways do the program's graduates perceive themselves as change agents? 
2. What is the effect of the teacher education program on graduates' ability to be collaborative team players?

3. What is the effect of the teacher education program on graduates ability to be lifelong learners?

4. How do teacher perceptions differ based on teaching experience?

5. What elements of the teacher education program do graduates feel prepared them for working in schools undergoing major school reform?

6. What elements of the teacher education program do graduates feel hindered their preparation for working in schools undergoing through major school reform?

7. How do the perceptions of teachers-as-change agents differ based on whether they are working in a school that has established a professional community with shared norms of collaboration?

\section{Program Description}

In 1989 , the graduate teacher education program started with a pilot of one elementary and one secondary cohort, while the remainder of the teacher education program continued at the undergraduate level. By the early 1990 s, the university eliminated the undergraduate option for teacher licensure. On average approximately 200 teachers have earned their initial teaching license in the program each year since. It remains the largest teacher license program in the state. More than 1,500 teachers have received teacher licenses since the program began in 1989.

The program provides options for authorization at four authorization levels: 
early childhood, elementary, middle level, and high school content specific

licensure. The admission requirements are rigorous. Applicants are required to have a minimum 3.0 gradepoint average (GPA) as an undergraduate, pass a basic skills test and content specific exams, submit letters of reference demonstrating experience working with children, and write a personal persuasive essay. In addition, applicants participate in a simulation in which they must solve a hypothetical pedagogical dilemma with three or four other applicants while professors and practitioners observe silently and look for evidence of creativity, collaboration, and leadership potential.

Although it varies, the applicant pool is usually large enough for the program to accept only about half of the applicants who apply each year. On occasion, if there are enough highly qualified candidates, the program is expanded to add cohorts to enable more candidates into the program. The typical candidate is in their thirties, white, and returning to school after pursing another career or parenting. The vast majority of graduates stay in the metropolitan region surrounding the university after program completion.

A conscious commitment to increase the enrollment of students of color is in place with varying levels of success. A small program, in conjunction with the local community college and school district provides full scholarships and guidance to minority students. This special guidance program succeeds in adding a small number of students of color into the program each year. In the last 5 years a separate bilingual teacher pathway was established to guide bilingual students who have been working as educational assistants through the initial licensure program. This program has helped 
to bring in more diversity into the institution. A concerted effort to recuit more minority faculty in the last 5 years has also enhanced the diversity agenda within the department. The faculty continues to seek opportunities to increase minority participation.

Once admitted into the program, the preservice teachers are clustered into cohorts in which students take the bulk of their classes together. Each cohort has approximately 30 students with one or two cohort leaders. The cohort model has the potential to provide students the opportunity to participate in social constructivism. Students learn to work collaboratively on projects and in study groups to socially construct their pedagogical understanding. Many of the cohort leaders select a theme of their choosing for their cohort, such as art infused curriculum, social justice, project based learning, literacy, or young adolescent development.

Clearly defined elements of the original program design have the potential to nurture the development of teacher change agents. A strong emphasis on comradeship and collaboration develops within a cohort. As the designers articulated in the focus group interview, one of the major goals of the program is to develop co-decision making skills. Cohort leaders work to develop a learning community in which preservice teachers reflect and leam how to work together. Motivated by Lortie's (1975) classic sociological study Schoolteachers: A Sociological Study, in which he described the isolation of teachers, the program designers were determined to help new teachers see teaching in a more collaborative light. One of the designers stated in the focus group session: 
We talked about the isolation in schools and there were many many times when we were modeling among ourselves, teaching how to be team members and work through problems with the hope that as change agents in schools they wouldn' $t$ be isolated and would learn how to work with their colleagues.

The program designers believed that before preservice teachers can move into collaborative problem solving, the primary emphasis must be the students. Preservice teachers are taught, "It's about the kids." One of the founders explained that the starting point for developing teacher change agents is to help new teachers understand that everything they do must revolve around what is best for students. New teachers must first develop credibility as competent teachers who meet their students' needs. As part of that process, new teachers must learn how to be reflective in collaboration with their peers to identify what is and is not working. They must take ownership for fixing the program when something is not working. Then one is ready to work for change. The original faculty modeled this practice, meeting weekly to discuss their own students needs. Although one of the founding faculty members insisted during the focus group discussion that, "beginning teachers camnot be change agents." Another of the designers clarified, "What we were leading to is not that someone starts as a change agent but they are prepared to be change agents." She went on to explain, "There are things that need to be set in place at the start that if they aren't, will insure that they will never be change agents or unlikely to be."

According to the program designers, another essential aspect of the program that could help prepare teachers to be open to change was the emphasis on new teachers becoming comfortable with ambiguity. Teachers must learn how to work 
creatively within externally mandated state constraints and parameters and still ask the question, "What else can I do?" Related to developing a comfort level with ambiguity was an intent in the original design to encourage risk-taking. Again, the original faculty modeled risk-taking as they continually revised the program throughout its first few years, experimenting with new strategies within the cohorts. The philosophy and intent of the program manifests itself within the cohort configuration. The cohort leaders have a tremendous impact on their students' development as they guide them through the entire 12 -month process. As cohort leaders have different levels of commitment to the original program design, participants will have a varied experience depending on who guides them through the process. Coursework includes pedagogy, both general and content specific, multicultural education, literacy across the curriculum, applied technology, special education, classroom management, and reflective practice. Program designers intended that at least one of the cohort leaders for each cohort has been a classroom teacher at some point in their career. Additionally, adjunct professors who are current classroom teachers frequently teach methods courses.

Early in the program, preservice teachers examine the socio-economic and cultural context of the students they will be teaching. As required by the state teacher licensing board, preservice teachers produce two "work samples" which entail the development of a unit of study that correlates with state standards, pre and post assessment, analysis of learning gains, a description of the context of the learning, along with an overall reflection of the unit's effectiveness. 
The program is an intense, fulltime commitment. Some part-time cohorts offered over the years enable students to continue working while attending classes. However, the majority of students are members of full-time cohorts and are advised not to work in outside jobs. The expectation is that they will participate in extensive fieldwork experience throughout the program, in addition to the course work. The program has been modified slightly since it started in 1989. Originally the program had a fall and spring start with preservice teachers completing all the course and fieldwork by mid summer of the next year or the winter of the following year. However, in 1999 , the program was moved to spring and summer start times so graduates could be available for jobs earlier in the hiring process. The field experience varies slightly depending on which of the two start times a cohort begins but both spring and summer cohorts have an initial field placement early in program with course work decreasing and field experience increasing each quarter. By the last quarter of the program, preservice teachers are expected to be active full-time staff members of their schools, with a cohort support seminar offered after school hours. With the addition of coursework in teacher research, and some electives it is possible for the students to complete a Master's in Education degree (M.Ed.) soon after completion of the licensure program.

\section{Socio-Political Context}

The urban teacher preparation program under examination was situated within a particular socio-political context. At the same time this program was designed, two major pieces of state legislation radically impacted the education community. The 
passage of a major state education reform calling for standards-based education influenced how teachers were expected to teach and thereby how to best prepare teachers for their role. More significantly, a law restructuring the state's tax structure severely limited funds to education and has had a serious negative impact on $\mathrm{K}-12$ and higher education. The 2001 passage of the federal legislation, No Child Left Behind and its definition of "highly qualified teacher" continues to impact the program as well (U.S. Office of Postsecondary Education, 2002).

The state is currently in a dire economic condition, holding the dubious honor of housing some of hungriest children and one of the highest unemployment rates of any state in the nation. The metropolitan area, in which the university is situated, was rated the highest unemployment rate of the 51 cities in the nation with more than one million people (U.S. Bureau of Labor Statistics, 2003). The proportion of children 18 and younger living in poverty climbed from $14 \%$ to $17 \%$ in 2002 , the highest rate in 8 years (Graves, 2003). At the same time housing prices in the city have risen beyond accessibility for the working poor. Many people of color and English limited students have moved out of the city into poorer suburbs.

Until very recently the city in which this the program is situated was able to boast a public school systen good enough to attract most of its middle class. Close to $90 \%$ of the city's children attend public schools. However, a steady decline in middle class attendance has occurred throughout the 1990 s as more resources and program cuts have taken place. The school district management has been in crisis for about 5 years with difficulties retaining a superintendent and dissension among school board 
members. In winter 2003 , a teachers' strike and a shortened school year were only averted by a last minute intervention from city officials and with teachers agreeing to work 10 days without pay. The district's crisis gained national notoriety when the Gary Trudeau's comic strip Doonesbury ran a series revolving around the shortened school year (Trudeau, 2003). Morale remains quite low in the schools. Like most urban school districts, a serious disparity exists between the haves and have-nots. The achievement gap between affluent white students and poor minority students is frustrating and embarrassing for the entire community. Despite bad press, there is no teacher shortage in this region. Program graduates face a highly competitive job market. Many of the last 5 years of graduates are struggling to secure jobs beyond long-term substitute positions and one-year contracts.

\section{Participants}

The target population consisted of all program graduates. Approximately 1,500 teachers have been licensed through this program since its inception in 1989. The primary sample of program graduates for this study was limited to those who are currently working in a school setting where they have the potential to be change agents. Approximately 1,200 surveys were mailed to all graduates on the alumni mailing list in an attempt to obtain a sample size large enough to be statistically significant. Of these, 192 were retumed for a response rate of $16 \%$. Twelve surveys were removed because the graduate was no longer a practicing teacher. An additional 102 surveys were administered during class to students completing the program with the much higher response rate of $88 \%$ (102 out of 116 students). It is hard to speculate 
why the return rate was so low from the mailed surveys. The final number of participants for the scale sample was 282 .

Fortunately, the 282 participants were remarkably representative of the population, despite the disappointingly low return rate. The small sample was well stratified by graduates teaching within different districts, teaching different age groups and different subjects, as well as by those who graduated in the early $1990 \mathrm{~s}$, the mid to later 1990 s, and during the last few years of the program. The gender distribution was about $2: 1$ female to male which was representative of the total teaching population. Although some years had more respondents than others, all 13 years of program graduates were represented in the sample. Just over half of the participants were high school teachers (53\%). Out of that group, $25 \%$ were English teachers, $20 \%$ were social studies teachers, and $16 \%$ taught science or health. Thirty percent of the participants were early childhood or elementary schools teachers while $23 \%$ taught middle school. Approximately $15 \%$ worked in English as Second Language (ESL) or special education (SPED). Most participants worked in public schools. About $4 \%$ of the graduates had moved into higher education. The sample is also stratified across cohorts. This is important because the experiences between cohorts can vary. It is important to note that the 102 participants who completed the modified surveys for this study did so at the conclusion of student teaching in one of the most hostile teaching environments of the last two decades, with pending shorten school years and teachers' threatening strikes. Their field experiences were not the same as those of other cohorts working in calmer political climates. 
Six program graduates participated in individual semi-structured interviews and shared their professional portfolios were analysis. These participants were part of a pilot group, completing a newly instituted continuing teacher licensure program requirement and not randomly selected program graduates. The six participants were purposively selected from three levels: two primary (grades $\mathrm{K}-3$ ) two intermediate (grades 4-8) and two high (grades 9-12). They all participated with informed consent. All six participants were working as classroom teachers and had taught a minimum of three years.

The two primary teachers interviewed were women who returned to school to become teachers later in life. One of the primary teachers was a middle-aged woman, who has been assigned the pseudonym "Ann." She returned to get her teaching license after having raised four children. Her youngest son had learning problems and had a miserable school experience. Ann was motivated to become a teacher who would meet the needs of children who learn differently. Two of her daughters were going through teacher education programs in another state while she was attending this program. Ann taught in the suburb in which she raised her children. The other primary teacher was also a middle-aged woman who has been assigned the pseudonym "Melissa." She came back to the university in order to receive a teaching license. Melissa had worked for more than 16 years in some of the city's poorest public schools as an educational assistant, running a school library but did not actually receive a college degree until her early forties. All of Melissa's work in schools was in diverse urban settings and her first job as a teacher was in one of the most diverse 
schools in the city system with more than $90 \%$ of the children on free or reduced lunch.

The two intermediate teachers had quite different experiences. One of the two intermediate level teachers, will be called "Jan." Jan taught in a Title I quasi-rural school and the other teacher, "Mike" taught in an affluent suburban middle school. Jan was much younger than the rest, probably in her mid twenties. She was supporting her husband while he completed his undergraduate education. Jan's husband also intended on pursuing a teaching career. Mike was the only male of the six participants. He did not complete his bachelor's degree until his late twenties and participated in the teacher licensure program at age 30 . Mike was the first in his family to complete college. He apparently had a rocky educational experience, having some undiagnosed leaming disabilities. He spent a lot of time in trouble during school. Mike brought to teaching a strong empathy for kids who struggle in school. The two high school teachers also brought an urban and suburban perspective to the study. One of the two high school teachers, I'll call "Molly," was a science teacher in the ciry and the other, "Carol" was a math teacher in a suburban school with a substantial Hispanic population. Molly was a young woman with a new baby. She drove a bus while working on her teaching license. Carol was a middle-aged woman who retumed to the university in her forties to get a teaching license.

A focus group of the four original faculty members who designed program was conducted to gain background knowledge about the program. Two out of the four program designers no longer worked with the program but agreed to participate in the 
focus group. "Mary" had retired and "Laura" was working as an educational consultant with a nonprofit educational organization. One of the faculty members, "Donna," currently with the program, had a unique perspective, in that she left the program and then returned after a few years. The final member of the original team, "Ben," had been in teacher education for more over 26 years and had consistently been involved in this program through its entirety.

\section{Research Design}

A triangulation mixed method study (Creswell, 2002) was designed to investigate the development of teacher change agents within a teacher preparation program. The researcher examined evidence of components of the construct of teachers-as-change agents of program graduates through a variety of methods. A cross-sectional comparison allowed the researcher to examine the perceptions of teachers-as-change agents at various stages of development

\section{Scale Data}

One component of the study entails the comparison of data from a scale administered to teachers at four different stages of development: The inservice teachers were clustered into three groups based on when they attended the program. Group I consisted of teachers who participated in the program in its first 5 years, 1989-1994. Group II was comprised of the teachers who participated in the program between 1995 and 1998. Group III included teachers who completed the program between 1998 and 2001. Additionally, there was one preservice group, Group IV who completed the program in 2003 . The scale was administered to graduates from 
Groups I, II and III who were teaching in a variety of institutional settings, grade levels, and subjects. By using a cross-section of graduates from different years, the researcher was able to explore the sustainability and developmental changes of teachers as they acquired more classroom experience. The modified scale administered to Group IV, preservice teachers, had a different number of items and could not be directly compared to the inservice teachers' scale. However, it was possible to compare the percent of mean scores of inservice and preservice teachers to identify similarities and difference in trends.

Portfolios and Interview Data

The researcher examined a sampling of continuing teaching license candidates' portfolios of program graduates to verify the scale's findings through the identification of artifacts that indicate participants' behaviors representing those of a teacher-aschange agent. Individual interviews were conducted with the participants who shared their portfolios. According to Kvale (1996):

Interviews are particularly suited for studying people's understanding of the meanings in their lived world, describe their experiences and self-understanding, and clarifying and elaborating their own perspective on their lived world. (p. 105)

The interviews in this study enabled the researcher to explore more deeply the dispositions of program graduates by providing the opportunity for participants to talk about their practice and what they perceived as of value in their preservice program and in their current teaching experiences. 
Focus Group Data

In addition, a small focus group was conducted with the four faculty members who designed the program. According to Vaughn, Schumm, and Singagub (1996) a focus group was an appropriate additional tool for this research study because it involved participants in an interactive dynamic discussion. This format enabled participants to reflect back together on the 14 years of the program's evolution as focus group participants grappled with ideas and perceptions among themselves. This provided a more complete picture of the program designers' original intent in regards to the development of teacher change agents. Vaughn et al. explained that one of the uses of focus groups, "as part of a portfolio of measures to triangulate data" (p. 15). The findings from the faculty focus group helped clarify for the researcher the intended goals of the program.

\section{Instrumentation and Materials}

Four different instruments were administered during this study: a scale, openended survey questions, interviews, and portfolio examination. A focus group was also used to establish some baseline data about the program.

Scales

A Teacher Adaptability Measurement Scale (TAMS) was designed by the researcher to specifically measure the construct of teacher-as-change agent among practicing teachers (see Appendix A). The TAMS consists of 30 items designed specifically for the purposes of this study. The construct of teacher-as-change agent has been addressed through items reflecting the three dimensions of teacher-aschange agent: teacher competence, teacher-as-learner, and teacher-as-an-advocate-for- 
students as explained in the operational definition section of this proposal. The scale was field tested by the staff of a suburban high school, as well as a group of $\mathrm{K}$ 12 teachers attending a professional development course at the university. Expert judges were called on to assess the scale. Some slight modifications were made based on the pilot group and experts feedback. For example, the pilot group reacted strongly to the term "educational reform" and it was subsequently removed from the final version of the scale. One of the experts recommended a 4-point scale over a 5-point scale to force participants to take a more clear position on items. A table of specifications was created to determine content validity. After gathering the data, a reliability analysis was run using the statistical program, SPSS. The Cronbach's alpha coefficient was determined to be .8859 , which is considered to reflect internal reliability across the items on the scale (Pallant, 2001).

The researcher designed and administered a modified TAMS (TAMS1) of 24 items to preservice teachers as they completed the program in spring 2003. TAMS1 is similar to the original TAMS designed for inservice teachers but adapted to reflect more closely the experiences of preservice teachers. TAMSI was piloted with a cohort of preservice teachers during the spring of 2002 (see Appendix B). Although the scales are not identical, the TAMSI does provide some baseline data to examine possible developmental changes and sustainability issues once graduates are out in the field. 
Table 1

Teacher Adaptability Measurement Scale: Table of Specification

Subset One: Teacher competence:

Subject matter knowledge

Pedagogical content knowledge

Pedagogical learner knowledge
Items 1, 2,

Items $7,4,10$

Items $3,5,6,8$

Subset Two: Teacher as learner:

Risk taker

Collaborator

Reflective practitioner
Items $14,15,16,18,20$

Items $11,12,13,16,18,19$

Items $13,17,18$

Subset Three: Teacher as advocate for students Items 21-30

Survey and Interview Questions

A page of four open-ended questions was attached to the scale. These asked graduates to write about components of the program that were (a) most helpful, (b) least beneficial, (c) helped sustain their passion. Finally the fourth question asked them to identify which elements of the program that they felt needed changing. A set of interview questions for the six participants was prepared to help verify and clarify findings from the portfolio review (see Appendix C). These were similar to the questions asked on the written survey distributed with the scale.

\section{Professional Portfolio Examination}

The six interviewees' professional portfolios were examined as artifacts. The portfolios had been written in conjunction with the completion of the state continuing license program. The portfolios consisted of numerous documents reflecting the teachers' perceptions of themselves as professional educators including: a personal 
teaching philosophy paper, two units of study with extensive analysis, critical questions the teachers explored, as well as five problem essays in which they probed deeply into their practice. The portfolios also included a description of the continuing teacher license candidate's professional growth and participation in their school community. Participants developed their portfolios over the course of 2 years. The portfolio was designed to demonstrate that the teachers had mastered 10 advanced competences as identified by the state licensing board and should therefore obtain a continuing teaching license as mandated. State reviewers had accepted the 6 teachers' professional portfolios as evidence of advancement to continuing teacher licensure within the last 6 months of the study (see Appendix D).

\section{Focus Group Questions}

A different set of open-ended questions was prepared for the faculty focus group (see Appendix E). The focus group questions were designed to determine if there had been any significant changes in the program over the years that may have influenced the preservice program's development of teacher change agents. The focus group session allowed the program designers to explain the original intent of the program and their perspectives on the program's potential role in the development of teacher change agents.

\section{Procedural Sequence}

The TAMS was field-tested with a group of teachers who had returned to the university for their CTL program, as well as staff from a local high school during fall 2002. The researcher had the opportunity to discuss with the pilot group their 
reactions to the scale. Participants expressed some confusion over the definition of "educational reform." Two different experts on scales also reviewed the scale and gave some layout, and wording suggestions before submission for human subjects review. Then the scale was mailed in June 2003 to approximately 1,200 program graduates. A bright pink follow-up postcard was sent out in July 2003 to increase the return rate. As of September 2003, only 192 graduates returned the survey. The 12 graduates who indicated that they were not currently in a classroom were removed from the pool. However, their surveys were retained for a possible follow-up study on retention rates. The researcher calculated descriptive statistics using the statistical program, SPSS, for the data from the 180 remaining surveys.

TAMS1 was first piloted with a spring 2002 cohort and was modified by the researcher to better match the context of a preservice teacher versus an inservice teacher. Preservice teachers completing their licensure program spring 2003 received the TAMS1. The researcher administered the TAMSI during class time so the return rate was $100 \%$ of those in attendance (102 surveys) or $88 \%$ of the total pool of 116 spring 2003 graduates. The researcher used SPSS to compare data from the four groups of participants.

The researcher identified six teachers who recently completed their continuing teaching license programs and were members of Group III, to be participants for more in-depth study. Individual interviews with the six participants were conducted during the summer and fall of 2003 . Four were interviewed at their homes, one at the researcher's home, and one participant was interviewed in his classroom after school. 
Each interview took approximately an hour to an hour and a half. The researcher employed the services of a professional transcriber to transcribe four of the interviews. The researcher transcribed the other two interviews. The researcher listened carefully to all the tapes while checking over the transcriptions to insure accuracy. The transcriptions were color-coded using the original three dimensions of the construct of teacher-as-change-agent as defined by the researcher: (a) competence, (b) learner, and (c) sense of agency. These three components were used as the prefigured categories using the "template analysis strategy" (Marshall \& Rossman, 1999). Appropriate direct quotes were identified as valid examples of participants' perspectives. After obtaining the appropriate permission, the researcher examined the six interviewees' portfolios. Data from the portfolios were categorized based on their written reflection of the attributes of teachers open to change as defined by the researcher. Data were analyzed to determine any emergent patterns. Responses in the interviews and open-ended questions at the back of scale were also coded to determine if patterns were evident or reflected across the portfolios, interviews, written responses, and in relation to responses on the scale. The six interviewees were given an opportunity to review the researcher's findings from the portfolio and interview analysis to verify that the researcher had accurately represented their perspectives.

The four faculty members who designed the program and were involved its early implementation participated in a small focus group with the researcher during June 2003. Sitting in the researcher's backyard, they discussed together, the goals, mission, implementation, and changes to the program throughout the years. The 
faculty members discussed their perceptions of the program's focus on the development of teachers as change agents. The focus group provided some information about program changes that might have influenced the development of teacher change agents.

Findings from the scales, open-ended questions, portfolio analysis, interviews, and focus group were compiled, compared, and analyzed in relation to the research questions and are reported in the findings and discussion chapters of this report.

\section{Variables in the Study}

As stated in the theoretical perspective with regard to the quantitative analysis of the research question, the teacher education program was the independent variable. Evidence of program graduates as change agents, as measured by the scale of teacher adaptability was the dependent variable. External variables included the number of years of teaching, the level of support within the school, age level of students, differences between cohorts, and the changes in the program over the years, as well as changes in the socio-political context in which teachers work. By using a stratified sample, the external variables were controlled sufficiently for the purposes of this study.

\section{Data Analysis}

The overall research question as to the influence of a teacher education program on the development of future teacher change agents was explored through analysis of the data gathered from teacher adaptability measurement scale (TAMS) of graduates from four different groups representing different time periods of the 
program. The data from the TAMS were entered into a statistical analysis program and frequency charts were run to look for patterns of responses. The researcher developed a table to display the rationale and statistical analysis procedures for each of six sub-questions (see Table 2). The seventh sub-question was not addressed in the table but will be discussed further in Chapter 5 .

Qualitative data from six professional portfolios were analyzed for emerging patterns. The researcher started the qualitative analysis by documenting evidence under each of the three components of the construct of teacher-as-change agent within program graduates' continuing license candidates' portfolios. Data were color-coded using a "template analysis strategy" (Marshall \& Rossman, 1999). The original three components: competence, learner, and agency, as discussed earlier as the dimensions of the construct of teacher change agent served as the prefigured categories. The portfolio examination was designed to verify whether the participants' perceptions as recorded on the scale matched their behaviors as documented in the portfolios. 
Table 2

The Analysis Process and the Rationale Behind Each Sub-Questions.

\begin{tabular}{|c|c|c|c|}
\hline Sub-question & Tool for analysis & Rationale & Information gained \\
\hline $\begin{array}{l}\text { 1. In what ways do } \\
\text { the program's } \\
\text { graduates perceive } \\
\text { themselves as } \\
\text { change agents? }\end{array}$ & $\begin{array}{l}\text { Frequency charts } \\
\text { and the use of } \\
\text { descriptive statistical } \\
\text { analysis }\end{array}$ & $\begin{array}{l}\text { Descriptive } \\
\text { question }\end{array}$ & $\begin{array}{l}\text { Will visually } \\
\text { show if graduates } \\
\text { see themselves as } \\
\text { change agents }\end{array}$ \\
\hline $\begin{array}{l}\text { 2. What is the effect } \\
\text { of the program } \\
\text { on graduates' } \\
\text { ability to be } \\
\text { collaborative }\end{array}$ & $\begin{array}{l}\text { TAMS: Frequency, } \\
\text { chart, graphs, mean } \\
\text { scores on sub-scale } \\
\text { on items addressing } \\
\text { collaboration }\end{array}$ & $\begin{array}{l}\text { Descriptive } \\
\text { question }\end{array}$ & $\begin{array}{l}\text { Isolates the } \\
\text { dimension of } \\
\text { collaboration }\end{array}$ \\
\hline
\end{tabular}

players?

\begin{tabular}{|c|c|c|c|}
\hline $\begin{array}{l}\text { 3. What is the effect } \\
\text { of the program } \\
\text { on graduates' } \\
\text { ability to be } \\
\text { life-long learners? }\end{array}$ & $\begin{array}{l}\text { TAMS: Frequency, } \\
\text { chart, graphs, mean } \\
\text { scores on sub-scale } \\
\text { on items addressing } \\
\text { lifelong learning }\end{array}$ & $\begin{array}{l}\text { Descriptive } \\
\text { question }\end{array}$ & $\begin{array}{l}\text { Isolates the } \\
\text { dimension of } \\
\text { life-long } \\
\text { learning }\end{array}$ \\
\hline $\begin{array}{l}\text { 4. How do teachers' } \\
\text { perceptions differ } \\
\text { based teaching } \\
\text { experience? }\end{array}$ & $\begin{array}{l}\text { TAMS: Descriptive } \\
\text { statistics followed by } \\
\text { ANOVA analysis }\end{array}$ & $\begin{array}{l}\text { Involves } \\
\text { comparison of } \\
\text { at least } 2 \text { groups } \\
\text { of people's mean } \\
\text { scores on a TAMS }\end{array}$ & $\begin{array}{l}\text { Isolates external } \\
\text { variable: teaching } \\
\text { experience }\end{array}$ \\
\hline $\begin{array}{l}\text { 5. What elements of } \\
\text { the program do } \\
\text { graduates } \\
\text { feel hindered their } \\
\text { ability to work } \\
\text { within schools } \\
\text { going through } \\
\text { reform? }\end{array}$ & $\begin{array}{l}\text { Tabulation of } \\
\text { responses clustered } \\
\text { by categories, patterns } \\
\text { coded, quantified by } \\
\text { category, }\end{array}$ & $\begin{array}{l}\text { Open-ended } \\
\text { responses need } \\
\text { categorizing, }\end{array}$ & $\begin{array}{l}\text { Will help identify } \\
\text { elements of program } \\
\text { that nurture } \\
\text { development of } \\
\text { teacher change } \\
\text { agents }\end{array}$ \\
\hline $\begin{array}{l}\text { 6. What elements of } \\
\text { the program do } \\
\text { graduates } \\
\text { feel helped prepare } \\
\text { them to work } \\
\text { within schools } \\
\text { going through } \\
\text { reform? }\end{array}$ & $\begin{array}{l}\text { Tabulation of } \\
\text { responses clustered } \\
\text { by categories, patterns } \\
\text { coded, quantified by } \\
\text { category, }\end{array}$ & $\begin{array}{l}\text { Open-ended } \\
\text { responses need } \\
\text { categorizing, }\end{array}$ & $\begin{array}{l}\text { Will help identify } \\
\text { elements of program } \\
\text { that nurture } \\
\text { development of } \\
\text { teacher change }\end{array}$ \\
\hline
\end{tabular}


The information obtained from the six interviews further enhanced the researchers' understanding of the influence/or lack thereof, the teacher education program might have on the development of teacher change agents. Kvale (1996) identified a number of steps to the analysis of an interview. According to his interview protocol, the first step is to let the interviewee describe spontaneously their answers to questions. The second step is to provide for the opportunity for the interviewee to potentially discover new relationships during the course of the conversation. The third step is for the interviewer to condense and interpret the meanings and reflect back that interpretation to the interviewee for validation. The fourth step is for the transcribed interview to be interpreted by the interviewer. The material must be condensed and categorized, significant representational narratives need to be identified, and then interpreted. Meaning condensation involves taking long statements and compressing them into briefer statements in which the main theme is maintained. In this particular study, meaning categorization involved categorizing the summarized meanings under the same three subcategories of the construct of teacher as change agent used in the portfolio analysis: competence, learner, agency. Finally, the researcher's interpretation was shared with the interviewees for comment and clarification.

The transcripts and notes from the focus group discussion with faculty were examined for evidence of the faculty's perception as to the role of preservice teacher education in the development of the three components of the construct of teacher as change agent. The big ideas were identified. The faculty members' responses were 
incorporated into the program description. Any significant changes in the program identified in the focus group were described in the program description.

To strengthen the study's results the researcher used triangulation of data from scales, open-ended questions, interviews, and portfolio examination. By incorporating the voices of 282 different participants who completed the scale and open-ended questions, the researcher was able to account for diversity across program graduates experiences both within the program and once they entered the work force. The six interviews and access to six professional portfolios enabled the researcher to take a deeper look at the behaviors and dispositions of some program graduates in order to determine if the characteristics of teacher change agents were evident. The next chapter will share the findings from the data gathered.

Delimitation and Limitations of the Study

The delimitation of the study is that it focused only on the program's ability to create teacher change agents not on the program's overall goals and purposes.

Limitations to the study included variability of candidates' beliefs and experiences. An important limitation was that teacher education candidates came into a program with preconceived notions as to whether a teacher should even consider it appropriate to take on the role of change agent in a school. Although some preservice teachers entered the program specifically to become teacher change agents, others entered the program because they enjoyed children or they were personally successful students within the current system. They may have held no clear sense of agency. In addition, many other factors influence a novice teacher's disposition. A teacher 
education program is just one influence on the development or lack of development of preservice teachers' desire to be change agents.

Another limitation was the variability of a preservice teacher's experience within any given teacher education program. No faculty member taught the courses in the same way. Although the course program of study and requirements for licensure were standard across the program, implementation varied by cohort. Although each cohort had its own emphasis, the program was evaluated as if all cohort experiences are uniform

In addition, the student teaching placement had a tremendous influence on student teachers' ultimate perception of themselves as teachers (Hoy \& Rees, 1977; Weiss \& Weiss, 2001). Most teacher education programs have little control over the field experiences of their program. As mentioned in the program description, the social and political settings in the schools in which participants" field experiences took place varied greatly depending on which year they entered the program. Those who participated in student teaching in 2003 faced very different learning environments than those who student taught during 1990 when the schools and their communities much more stable.

Another limitation to the study was that a teacher education program has very little influence over the conditions within the schools where its graduates work. Some program graduates were hired in schools already steeped in positive educational reform, with well-established professional communities, and a shared norm of collaborative practice and growth. Others taught in buildings where the norm was to 
shut doors and survive as best they could conditions that appeared to be overwhelmingly stacked against making positive change (Hargreaves \& Jacka, 1995). All program graduates hired within an Oregon public school faced the tension of tremendous budgetary constraints along with externally imposed pressures to have all students pass standardized tests. Though strong mitigating factors have the potential to interfere with a teacher education program's ability to impact change, these factors were taken into consideration when designing this study of a teacher education program's ability to nurture future change agents.

\section{Trustworthiness}

The researcher designed procedures to ensure the trustworthiness of the study's findings. Although the sample size was smaller than the researcher would have liked in regards to total population size, it still was remarkably representational of the total population of program graduates. First, a range of perspectives was represented by using the scale with program graduates from different years, various cohorts, and who teach in a variety of school setting. Precautions were set in place to ensure the researcher did not misinterpret the qualitative aspects of the study. For example a variety of voices and perspectives were included. The sample represented teachers of different age students at very different school sites. Having participants review the sections the researcher had interpreted from their portfolios and interviews ensures accurate representation of their perspectives. Overall, the research findings are trustworthy because multiple voices are represented from a variety of sources within the portfolios, the scale, and the survey. 


\section{CHAPTER IV}

\section{FINDINGS}

This study was designed to determine whether characteristics of teacherchange-agents were evident in a particular teacher education program's graduates. For the purposes of this study the operational definition of a teacher-change-agent was divided into three components: (a) competence, (b) learner, and (c) sense of agency. As defined earlier, "competence" refers to teachers who have the necessary content knowledge, pedagogical content knowledge, and understanding of learning theory and culturally responsive teaching to be effective educators. The component, "learner" refers to characteristics of teachers who are lifelong collaborative learners, who bring personal relevance to their work, reflect on their practice, and take risks as they continually work at perfecting their practice. The third component addresses the disposition of teachers who have a strong "sense of agency," teachers who believe they can make a difference in the lives of their students, maintain their passion, commitment, and willingness to change their practice in order to meet students' needs.

The findings have been organized around each of the original research questions. The data from the Teacher Adaptability Measure Scale (TAMS) were used to examine research sub-questions 1 through 4 . Sub-questions 5 through 7 were addressed using the data from the open-ended survey questions, the interviews, and 
the portfolio analysis. The questions addressed primarily by the quantitative data obtained from the TAMS responses are discussed first. The questions addressed primarily through the qualitative data follow.

\section{Findings from the Quantitative Data}

\section{Sub-Question 1 .}

In what ways do the program's graduates perceive themselves as change agents?

Rather than ask program graduates directly if they perceived themselves as change agents, the researcher designed the TAMS to measure self-reported behaviors that reflected characteristics of teachers open to change. The items were rated on a 4 point scale: 1 = never, 2 = sometime, 3 = usually and $4=$ always. By examining the mean scores and percent of responses for each response option, it was possible to identify patterns of behaviors of teachers open to change. For a table that summarizes the responses to all 30 items see Appendix F. Data on the highest frequency responses from the TAMS are summarized in Table 3.

Four out of the five most frequently reported behaviors by groups I, II, and III, inservice teachers fell into the agency subscale of the TAMS. More than $95 \%$ of inservice teachers reported either "usually" or "always" seeking outside consultation when concerned about the emotional well being of a student. The mean score for consulting on students' emotional well-being was $3.76(S D .50)$. These findings reflect a high level of care for the welfare of their students, as well as a recognition of the importance of collaboration. Again, $95 \%$ of the inservice teachers reported a belief in their students' ability to succeed, at a very high rate, with a mean score of 
3.68 (SD 50 ). In addition, inservice teachers also reported getting to know their students as individuals at a high rate of $3.63(S D .56)$. Over $90 \%$ of participants reported high levels of reflection as indicated by a mean score of 3.54 (SD.63) on the item "I reflect on the effectiveness of my lessons." Finally, participants reported seeking consultation when concerned about the academic well being of a student at similarly high rates, with a mean score of $3.52(S D .63)$. More than $90 \%$ of inservice teachers reported either "usually" or "always" seeking help with the academic needs of their students. These findings reflected teachers who have a strong sense of agency and an openness to collaboration.

Table 3

Highest Frequency Responses of Inservice Teachers Reflecting Characteristics of Teachers-as-Change-Agents

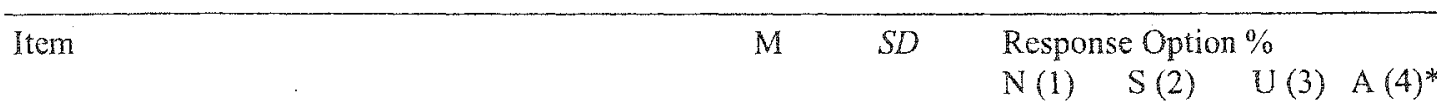

Inservice Teachers $(n=180)$

\begin{tabular}{|c|c|c|c|c|c|c|}
\hline $\begin{array}{l}\text { I seek consultation when concerned about } \\
\text { the emotional well being of a student. }\end{array}$ & 3.76 & .50 & 0 & 3.3 & 17.2 & 78.9 \\
\hline I believe that all students can succeed. & 3.68 & .50 & 0 & 1.7 & 28.3 & 69.4 \\
\hline $\begin{array}{l}\text { I get to know my students as individual } \\
\text { human beings. }\end{array}$ & 3.63 & .56 & 0 & 3.9 & 28.9 & 66.7 \\
\hline $\begin{array}{l}\text { I reflect on the effectiveness of my lessons } \\
\text { and unit plans. }\end{array}$ & 3.54 & .63 & .6 & 5.6 & 33.3 & 60.0 \\
\hline $\begin{array}{l}\text { I seek consultation when concemed about } \\
\text { the academic well being of a student. }\end{array}$ & 3.52 & .63 & 0 & 7.2 & 33.3 & 58.9 \\
\hline
\end{tabular}

Note: $\mathrm{N}=$ never, $\mathrm{S}=$ sometimes, $\mathrm{U}=$ usually, $\mathrm{A}=$ always

When looking at the range of responses, none of the items on the inservice teachers' scale had mean scores that indicated low levels of involvement in behaviors 
characteristic of teachers open to change. The lowest mean scores still reflected moderate levels of behavions. However, examining the five items with the lowest scores provided information as to what areas might need reinforcement through professional development (see Table 4). The item with the lowest mean score addressed the inservice teachers' frequency of inclusion of students' voices in the design of classroom and curriculum content. The mean score for this item was 2.36 (SD .72). This standard deviation indicates that there was a wide range of response. Seven percent of the teachers reported never including student voice in their curriculum. Fifty-five percent of the teachers reported sometimes including student voice. Thirty percent reported giving students" voice "usually" and only $6.7 \%$ reported "always" including students in their curriculum design. The next lowest mean score (2.45) was reported for an item that addressed inviting colleagues to observe and discuss one's practice. An even wider range of responses to this item was reported with a standard deviation of 93 . Thirteen percent of the inservice teachers reported never inviting colleagues to observe, but another $16.7 \%$ reported "always" inviting in their colleagues. Inservice teachers did not report utilizing community resources to enhance their teaching at a particularly high frequency. The mean score for the item discussing use of community resources was 2.52 (SD .82), with more than $50 \%$ reporting "never" or only "sometimes" taking advantage of community resources in their teaching. Although inservice teachers self-reported that they got to know their students well, they did not report particularly high frequencies of getting to know their students' families. The item addressing getting to know families received a mean 
score of $2.60(S D .81)$ with more than $50 \%$ of participants reporting "never" or "sometimes" getting to know families. Finally, inservice teachers reported moderate frequencies of running their classrooms democratically. The item referring to democratic classrooms received a mean score of $2.73(S D .76)$ with $39.5 \%$ of inservice teachers reporting "never" or "sometimes" running democratic classrooms and $58.9 \%$ reporting "usually" or "always" running their classrooms democratically. Refer to Table 3 and 4 for a summary of the highest and lowest frequencies of responses.

Table 4

Lowest Frequency Responses of Inservice Teachers Reflecting Characteristics of Teachers-as-Change Agents

\begin{tabular}{|c|c|c|c|c|c|c|}
\hline \multirow[t]{2}{*}{ Item } & \multirow[b]{2}{*}{$M$} & \multirow[b]{2}{*}{$S D$} & \multicolumn{3}{|c|}{ Response Option $\%$} & \multirow[b]{2}{*}{$A(4)^{*}$} \\
\hline & & & $N(1)$ & $\$(2)$ & $U(3)$ & \\
\hline \multicolumn{7}{|c|}{ Inservice Teachers $(n=180)$} \\
\hline $\begin{array}{l}\text { I give students voice in the design and } \\
\text { curriculum content. }\end{array}$ & 2.36 & .72 & 7.2 & 55.6 & 30. & 6.7 \\
\hline $\begin{array}{l}\text { I invite colleagues to observe and } \\
\text { discuss my practice. }\end{array}$ & 2.45 & .93 & 13.3 & 44.4 & 25. & 16.7 \\
\hline $\begin{array}{l}\text { I utilize community resources to enhance } \\
\text { my teaching. }\end{array}$ & 2.52 & .82 & 5.6 & 51.7 & 26.7 & 15.6 \\
\hline I get to know my students' family. & 2.60 & .81 & 4.4 & 46.7 & 32.2 & 15.6 \\
\hline I run my classroom democratically. & 2.73 & .76 & 2.8 & 36.7 & 42.8 & 16.1 \\
\hline
\end{tabular}

Note: $\mathrm{N}=$ never, $\mathrm{S}=$ sometimes, $\mathrm{U}=$ usually, $\mathrm{A}=$ always

Group IV, the preservice teachers were given TAMS 1, a modified version of the TAMS with 24 items. They reported similar behaviors, but also revealed some differences (see Table 5). Preservice teacher also reported getting to know their 
students. Approximately $95 \%$ report either "usually" or "always" knowing their students well. Similar to the inservice teachers, approximately $94 \%$ of preservice teachers reported a strong willingness to seek consultation from others in order to help students' emotional and academic well-being. An unexpected finding was that preservice teachers self-reported high confidence in their ability to design lessons that were actively engaging students with the subject matter. Almost $98 \%$ claimed to have mastered this advanced skill. Ninety-five percent of the preservice teachers reported experimenting with new strategies on a frequent basis. Although, only a slight majority of inservice teachers reported attending professional conferences, all but three of the preservice teachers reported that they planned to attend professional conferences annually. Finally, like the inservice teachers, preservice teachers reported believing that all of their students can succeed. With a mean score or 3.79 (SD .46), approximately $95 \%$ of preservice teachers reported either "usually" or "always" believing that all students can succed. Data from the TAMS1 identifying the most frequently reported behaviors are summarized in Table 5. Some of the items on the TAMSI were just "yes/no" while others were on a 4-point scale similar to the TAMS making it more difficult to compare the data. 
Table 5

Highest Frequency Responses of Preservice Teachers Reflecting Characteristics of Teachers-as-Change-Agents

Item $\quad$ Response Option \%

Preservice Teachers $(n=102)$

Lessons I design actively engage students

No (1)

Yes (2)

with subject matter.

97

1.0

I intend to attend professional

93

3.1

conferences and workshops

\begin{tabular}{|c|c|c|c|c|c|c|}
\hline & $\mathrm{M}$ & $S D$ & $N(1)$ & $S(2)$ & $U(3)$ & $\mathrm{A}(4)^{*}$ \\
\hline I believe that all students can succeed. & 3.79 & .46 & 0 & 2.1 & 16 & 78.0 \\
\hline $\begin{array}{l}\text { I seek consultation when concerned about } \\
\text { the emotional well being of a student. }\end{array}$ & 3.70 & .52 & 0 & 3.1 & 22.7 & 71.2 \\
\hline $\begin{array}{l}\text { I get to know my students as } \\
\text { individual human beings. }\end{array}$ & 3.67 & .53 & 0 & 3.1 & 25.8 & 69.1 \\
\hline
\end{tabular}

* Note: $\mathrm{N}=$ never, $\mathrm{S}=$ sometimes, $\mathrm{U}=$ usually, $\mathrm{A}=$ always

Group IV, preservice teachers reported some areas of weakness similar to the inservice teachers, as well as a few areas that were unique to Group IV. For instance, preservice teachers also did not report knowing how to utilize community resources. More than $25 \%$ of the preservice teachers reported never having been taught to use community resources in their teaching. Not one preservice teacher reported "usually" or "always" utilizing community resources. Preservice teachers also did not report getting to know the families of their students. Over $55 \%$ reported never or sometimes getting to know their students' families, $5 \%$ less than inservice teachers. Assessment was an area of more concern for preservice teachers than inservice teachers. Close to 
$75 \%$ of the preservice teachers claimed to have not been taught how to match assessments with unit objectives. Although they reported a slightly higher frequency than the inservice teachers, the preservice teachers did not include student voices in their curriculum design with great frequency. Their mean score for the item addressing student voice was $2.63(S D .83)$. Approximately $95 \%$ reported "sometimes" collaborating with their cohort members but none of preservice teachers felt collaboration was "usually" or "always" happening. Unlike the inservice teachers who self-reported very high levels of collaboration, the preservice teachers reported moderate levels of collaboration with members of their cohorts. The summary of low frequency rates for preservice teachers reflecting characteristics of teachers as change agents is presented in Table 6. As in the case of the highest frequency responses, some of the items were "yes/no" responses and others were on a 4-point scale. A table summarizing preservice teacher's responses to all 24 items on the modified TAMS1 was created (see Appendix G). 
Table 6

Lowest Frequency Responses of Preservice Teachers Reflecting Characteristics of Teachers-as-Change-Agents

Item Response Option \%

Preservice Teachers $(n=102)$

I was taught how make assessments I design

No (1)

73.2

$\mathrm{Yes}(2)$

match my unit objectives.
24.7

\begin{tabular}{|c|c|c|c|c|c|c|}
\hline & $\begin{array}{l}M \\
(4)^{*}\end{array}$ & $S D$ & $N(1)$ & $S(2)$ & $\mathrm{U}(3)$ & A \\
\hline I learned to utilize community resources & 1.29 & .54 & 25.8 & 72.2 & 0 & 0 \\
\hline I get to know my students' families. & 2.47 & .71 & 4.1 & 51.5 & 34.0 & 8 \\
\hline $\begin{array}{l}\text { I give students voice in the design and } \\
\text { curriculum content. }\end{array}$ & 2.63 & .82 & 5.3 & 42.3 & 34.0 & 0 \\
\hline $\begin{array}{l}\text { I work collaboratively with members } \\
\text { of my cohort }\end{array}$ & 2.88 & .82 & 3.1 & 94.8 & 0 & 0 \\
\hline
\end{tabular}

* Note: $\mathrm{N}=$ never, $\mathrm{S}=$ sometimes, $\mathrm{U}=$ usually, $\mathrm{A}=$ always

Items on the TAMS were clustered into subscales to determine if there were any variations between the levels of behaviors among the three components of teachers open to change: competence, learner, and agency. The mean scores were determined for each subscale. The data from both the inservice and preservice subscales and the total combined scores are presented in Table 7. The learner subscale for both inservice and preservice teachers is discussed separately as it was addressed in a specific research question. The inservice competence subscale had a mean score of 23 (SD 2.83) with a range of $15-28$. This indicated that $95 \%$ of the inservice teachers rated themselves moderately competent. The total mean score for the 
"agency" subscale was 31.8 (SD 3.8) with a range of 23-40. Again, this indicated that the vast majority of participants reported themselves as involved in behaviors that reflected a teacher who had at least a moderate sense of agency for his/her students. The inservice teachers' total mean score combining all items was 84.7 (SD 9.77) with a range of $63-106$ out a possible 108 . This showed overall levels of moderately high involvement in behaviors associated with teachers open to change. The significance values were all three subcategories and across the groups were higher than .05 when the Kolmogorov-Smirnov statistics tests for normality were conducted using SPSS. This indicates the distributions of participants' scores were found to be within the normal range (Pallant, 2001).

Table 7

Descriptive Statistics: TAMS Subscales

\begin{tabular}{|c|c|c|c|c|c|c|}
\hline \multirow[b]{2}{*}{ Subscale } & \multicolumn{3}{|c|}{ Inservice Teachers $(n=174)$} & \multicolumn{3}{|c|}{ Preservice teachers $(n=94)$} \\
\hline & Mean & $\mathrm{SD}$ & Range & Mean & $\mathrm{SD}$ & Range \\
\hline Competence & 23.0 & 2.83 & $15-28$ & 13.81 & 1.08 & $10.5-15$ \\
\hline Learner & 29.8 & 4.50 & $20-40$ & 11.1 & 0.71 & $9-12$ \\
\hline Agency & 31.8 & 3.80 & $23-40$ & 32.5 & 4.10 & $20-40$ \\
\hline Collaboration & 20.4 & 3.59 & $10-28$ & 11.93 & 1.47 & $7-14$ \\
\hline Teacher Change Agent & 84.7 & 9.77 & $63-106$ & 57.39 & 4.52 & $44-67$ \\
\hline
\end{tabular}

The preservice teachers total mean scores on the subscales and combined totals were also tabulated. The total mean score for preservice subscale of competence was 13.81 (SD 1.08) with a range of 10.5-15 out of a possible 16. The preservice teachers 
self reported quite high in regards to competence. Finally, the mean score for the preservice agency subscale was 32.5 (SD 4.2) with a range of 20-40. This showed a wider range of responses, but all preservice teachers reflected some sense of agency for their students. The preservice teachers' total combined mean score was 57.39 (SD 4.52) with a range of 44-67 out of a maximum possible score of 84 . Despite the wide range of responses, the data indicate that preservice teachers, by in large self-reported moderately high levels of behaviors across the scale that reflected someone with the potential to be a teacher change agent.

\section{Sub-Question 2.}

What is the effect of the teacher education program on graduates' ability to be collaborative team players?

In order to address the question as to whether program graduates were involved in collaborative practices, a seven-item collaboration subscale was created from the 30 item TAMS. The data from this subscale are also shown in Table 7 . The inservice teachers' mean score on the collaboration subscale was 20.4 (SD 3.59) with a range of 10-28. This indicated moderate levels of involvement in collaborative activities by program graduates. The preservice teacher scale had four items that directly addressed collaboration. The total mean score for the preservice teachers' collaboration subscale was 11.93 (SD 1.47) with a range of $7-14$ out of a possible 16 . Although when specifically asked if they felt collaboration was happening within their cohort, all the preservice teachers reported collaboration happening only "sometimes," the combined collaboration score for preservice teachers was at a moderate level. 
Sub-Question 3 .

What is the effect of the teacher education program on graduates' ability to be life-long leamers?

The question of program graduates' ability to be lifelong learners was addressed through a 10 -item leamer subscale of the TAMS. Data from the learner subscale are summarized in Table 7. The mean score on the learner subscale was 29.8 (SD 4.5) with a range of $20-40$. This indicated that while most of the inservice teachers rated themselves as moderately active learners, there was a wide range of participants. Some teachers rated themselves moderately low while others saw themselves as very active learners. In comparison, the preservice teachers' responses were not as varied. The total mean score for the preservice learners subscale was 11.1 $(S D .71)$ with a range of $9-12$ out of a possible 14 . This showed a much more tightly clustered array of responses with most preservice teachers reporting themselves as active learners.

\section{Sub-Question 4.}

How do teacher perceptions differ based on teaching experience?

This question was designed to explore the sustainability of the teaching principles presented during the preservice program. To address the question of sustainability, the scores from the inservice teachers were disaggregated into three different groups. Group I was composed of the teachers who participated in the program during the first 5 years from 1989-1994. The teachers who participated in the middle years of the program from 1995-1998 were clustered together as Group II. Finally, the teachers who participated most recently in the program from 1999-2001 
were clustered together as Group III. An Analysis of Variance (ANOVA) found no statistically significant difference in any of the three subscales among the three groups. Additionally, Pearson's correlations found no statistically significant correlations among the three subscales. However, when the Pearson's correlation was used to search for a possible correlation with the number of years taught a correlation was revealed regarding the use of assessments matching objectives. The more years a teacher taught, the more they reported frequent alignment between their assessments and unit objectives; $r=.244, p<.001$. This finding supported the position of $73.2 \%$ of the preservice teachers who reported that assessment had not been sufficiently taught during the program.

\section{Summary of Quantitative Findings}

The quantitative data gathered from program graduates across the entire duration of the program allowed the researcher to look at evidence addressing research questions 1 through 4 . The data indicated that teachers self-reported very high levels of reflection. The teachers reported comparatively high levels of collaboration, including seeking consultation on both the emotional and academic well being of their students. Both inservice and preservice teachers reported believing their students can succeed. They knew their students well but did not report getting to know their students' families as frequently. Inservice teachers were not including the voices of their students in curriculum design very frequently. Related to a lack of interaction with the families were the teachers' low levels of reporting taking advantage of community resources. Years of experience did not result in significant variations in 
level of self-reporting behaviors associated with characteristics of teacher change agents, except in the one area of assessment skills. Assessment skills increased with the years of teaching experience. The vast majority of program graduates across the years reported practicing some behaviors within all three subcategories of teachers open to change: competence, learners, and agency.

\section{Qualitative Findings}

Qualitative data were collected from three different sources: (a) open-ended responses to a written survey, (b) transcriptions of semi-structured interviews with six graduates, and (c) analysis of six professional portfolios.

\section{Open-Ended Responses}

The primary purpose of the scale was to determine whether program graduates would self-report involvement in behaviors that reflected a teacher open to change. The additional page of questions attached to the scale were intentionally open-ended so the researcher could determine if teachers would spontaneously identify elements of the program geared to nurturing teachers-as-change-agents as something that either benefited, hindered their development, or helped to sustain their passion for teaching. No limits were set as to the number of elements that could be listed and some people identified numerous elements under each category.

Teachers' comments were clustered by the same four groups described in the quantitative findings based on when they participated in the program. The four groups included: Group I (1989-1994), Group II (1995-1998), Group III (1999-2001) and Group IV (Summer 2002). Although the descriptive statistics did not show 
statistically significant variation of responses between the groups, the responses to the open-ended questions do show some differences.

\section{Sub-Question 5 .}

What elements of the teacher education program do graduates feel prepared them for working in schools undergoing major school reform?

Sub-question 5 was addressed through an examination of the responses to the open-ended questions. The way teachers responded to these questions revealed whether they identified attributes of the program that nurtured the characteristics of teachers open to change.

Regardless of program start date, the majority $(56 \%)$ identified field experiences as the most beneficial element of their preservice program. One teacher wrote, "Student teaching made teaching a reality." Another teacher stated, "Reality helps!" However, after field experiences the most frequently identified benefit of the program varied depending on program start date. For instance, $33 \%$ of Group I teachers identified best practices and methods twice as often as teachers from Group II (16\%) and Group IV (17\%) and one third more often than teachers from Group III $(27 \%)$

The cohort model and collaborative learning were listed by $25 \%$ of all teachers as the most beneficial element to the program. Although this varied considerably depending on when teachers participated in the program. For example, 32\% of Group II listed collaborative work in cohorts as most beneficial, but only $10 \%$ of Group IV mentioned the cohort model as being beneficial. A Group III teacher described the 
feelings of many: "Interaction with cohort, learning to share both success and failures helped me to recognize I can share problems I experience with other teachers to get feedback and advice." These graduates had internalized the value of collaborative reflection.

Many teachers listed learning classroom management strategies as an important benefit of the program. Group IV, preservice teachers, identified the classroom management course as beneficial at a slightly higher rate than the rest of the participants ( $23 \%$ versus $19 \%$ of the total). A professor, who was with the program for 13 years taught the majority of the classroom management classes. Forty-two different graduates specifically mentioned his name in relation to that class $(16 \%)$. A Group I teacher who taught for 12 years wrote about this professor's classroom management class, "I still consciously use techniques, strategies, and suggestions he gave us for the well-being of my students and myself, and for the effectiveness of teaching and having a centered presence with students." A Group IV teacher concurred, "Classroom management with Ben (alias) is awesome and extremely necessary for today's teaching." This professor had a sustaining influence on a large number of program graduates teaching careers.

Thirty-eight graduates (13\%) noted inspiring professors and quality mentor teachers as important benefits of the program. A much smaller percentage of graduates (5\%) complained of "out of date" or "disengaged professors." The percentage of program graduates who identified either an inspiring professor or mentor teacher as the most valuable aspect of the program varied considerably 
depending on the years they attended the program. Group II participants were particularly impressed with their leaders. Thirty percent of the Group II identified an inspiring leader, $22 \%$ of Group III listed the value of inspirational leaders. Only $3 \%$ of Group I and $5 \%$ of Group IV identified inspiring professors and mentors as the most beneficial aspect of the program. One graduate wrote that the most beneficial element of the program was "Having cohort leaders who were passionate about teaching and informed about the latest teaching practices." Relationships developed between cohort leaders and their students had a lasting effect on some program graduates.

An understanding of learning theory and the relationship of teaching and learning was identified by $6 \%$ of teachers across the years. Thirteen percent of Groups I and III, $8 \%$ of Group II, and $5 \%$ of Group IV identified learning theory as one of the most beneficial aspects of the program. A Group III teacher wrote, "Discussing recent learning theory was fascinating and useful." A Group I teacher wrote that there was an "excellent balance between theory and practice." However, some participants also listed learning theory as a deficit of the program. Ten percent of the teachers expressed a disconnect between theory and practice.

Although not officially part of the licensure program, four inservice teachers listed the action research class as the most beneficial part of the program. Notably, the action research course was offered after completion of the licensure program as part of the master's degree.

Table 8 summarizes the data collected from the responses to a question asking 
teachers to identify what elements of their preservice program were most beneficial in preparing them for the realities of teaching in a $21^{\text {st }}$ century public school.

Table 8

Comparison of Responses as to the Most Beneficial Program Experiences*

\begin{tabular}{|c|c|c|c|c|c|}
\hline & $\begin{array}{l}\text { Total } \\
\mathrm{n}=275 \%\end{array}$ & $\begin{array}{l}\text { Group I } \\
(1989-1994) \\
n=54\end{array}$ & $\begin{array}{l}\text { Group II } \\
(1995-1998) \\
n=56\end{array}$ & $\begin{array}{l}\text { Group III } \\
(1999-2001) \\
n-63\end{array}$ & $\begin{array}{l}\text { Group IV } \\
(2002) \\
n=102\end{array}$ \\
\hline $\begin{array}{l}\text { Field } \\
\text { Experiences }\end{array}$ & $155(56 \%)$ & 35 & 42 & 38 & 55 \\
\hline $\begin{array}{l}\text { Best practices/ } \\
\text { Methods }\end{array}$ & $76(28 \%)$ & 18 & 9 & 17 & 17 \\
\hline $\begin{array}{l}\text { Cohort Model/ } \\
\text { Collaboration }\end{array}$ & $70(25 \%)$ & 13 & 18 & 18 & 10 \\
\hline $\begin{array}{l}\text { Classroom } \\
\text { Management }\end{array}$ & $54(20 \%)$ & 5 & 11 & 8 & 23 \\
\hline $\begin{array}{l}\text { Mentor teachers/ } \\
\text { Leaders }\end{array}$ & $38(13 \%)$ & 2 & 17 & 14 & 5 \\
\hline $\begin{array}{l}\text { Multicultural/ } \\
\text { ELL }\end{array}$ & $29(11 \%)$ & 6 & 6 & 6 & 11 \\
\hline $\begin{array}{l}\text { Reflective } \\
\text { Practice }\end{array}$ & $17(6 \%)$ & 4 & 2 & 6 & 5 \\
\hline $\begin{array}{l}\text { Teaching/ } \\
\text { Learning theory }\end{array}$ & $16(6 \%)$ & 7 & 5 & 8 & 5 \\
\hline Technology & $14(5 \%)$ & 0 & 3 & 6 & 5 \\
\hline $\begin{array}{l}\text { Special } \\
\text { Education }\end{array}$ & $14(5 \%)$ & 2 & 1 & 4 & 7 \\
\hline
\end{tabular}

*Note: Taken from Survey Question 1: What types of experiences during the Graduate Teacher Education Program were most beneficial in preparing you for the realities of teaching in a $2 l^{\text {st }}$ century public school? 
Sub-Question 6.

What elements of the teacher education program do graduates feel hindered their preparation for working in schools undergoing major school reform?

Sub-Question 6 was addressed by examining the responses to the open-ended question that asked teachers to identify which elements of their preservice program were least helpful in preparing them for the realities of teaching in a $21^{\text {st }}$ century public school.

Methods courses proved to be a somewhat controversial aspect to the program. Some teachers considered the methods courses to hinder their preparation as teachers while others identified their methods classes as one of the most beneficial aspects of the program. Twenty-two percent of teachers listed irrelevant or weak methods as something that hindered them. At the same time, $27 \%$ of other teachers listed their methods courses as the most beneficial. Perceptions of the value of methods courses varied depending on when teachers participated in the program. The participants from Group II listed irrelevant or weak methods $37 \%$ of the time and only identified methods courses as beneficial $16 \%$ of the time. Group IV, preservice teachers, listed methods courses as a hindrance to their preparation $18 \%$ of the time, while another $17 \%$ of this group listed the methods courses as one of the most beneficial aspects of the program.

Teachers' perceptions of the technology courses also changed over the years. None of the teachers from Group I (1989-1994) identified technology as most beneficial, but $9 \%$ of Group III identified technology as one of the most beneficial 
elements of the program. The number of teachers who saw the technology course as a hindrance decreased from a high of $18 \%$ in Group I to a low of $2 \%$ in Group II. Eleven $\%$ of Group III and $8 \%$ in Group IV expressed dissatisfaction with the technology course during the program. Again, other teachers from Groups II, III and IV identified technology as an asset.

Multicultural education was another course that elicited a different reaction from various teachers. Multicultural education was recognized as an important feature of the program by only about $11 \%$ of all graduates. One teacher wrote that the most beneficial element of the program was the "extensive important literature addressing diverse cultures." Another listed under most beneficial, "discussion of race, gender, sexual orientation." However, 7\% of teachers listed the program's emphasis on multicultural education as a hindrance. Some participants complained there was too much emphasis on diversity and social justice, while others complained there was not enough.

Reflection was identified by a small number of teachers as an important element of the program. A range of $4 \%$ to $9 \%$ of teachers listed reflective practice as most beneficial. Some mentioned reflection in relation to collaborative sharing in their cohorts, "learning together through discussions." Whereas, $6 \%$ of participants saw the emphasis on reflection as beneficial, a different $5 \%$ saw it as excessive and least helpful. Their perceptions as to the value of reflection varied depending on the years they completed the program. Among the participants from Group I, who have been out in the field the longest, $8 \%$ listed it as most beneficial and no one listed 
reflection as a program deficit. Four percent of Group II, $6 \%$ of Group III and 10 $\%$ of Group IV listed reflection as something that hindered them.

Classroom management was another area that was listed as both most beneficial and as lacking by some teachers. Although, the classroom management course was identified $19 \%$ of the time as most beneficial and $4 \%$ of the time as the course that helped sustain their passion, a different $6 \%$ of participants complained the course was inadequate or too idealistic.

Preparation in teaching English as a Second Language (ESL) and special education also received a mixed rating. Five percent, or 14 participants, listed preparation in special education and ESL as the most beneficial element of the program. An even smaller group of eight teachers $(3 \%)$ listed the training in special education and ESL as inadequate. Dissatisfaction with ESL and special education preparation varied considerably depending on when teachers participated in the program. ESL and special education training was listed as inadequate by $11 \%$ of Group I, $4 \%$ of Group II, $5 \%$ of Group II, and only $2 \%$ of Group IV.

A few teachers ( $8 \%$ ) expressed concern about the lack of guidance and communication while out in the field. Group IV, the preservice teachers complained more often about communication issues than the rest of the participants. Thirteen percent of Group IV listed communication as the element of the program most in need of change.

Overall, program graduates had far more positive comments about the program than negative remarks. A number of teachers were very satisfied with the program. 
Fifteen percent of the teachers either left the question as to the least helpful aspects of the program blank or wrote "none." One teacher wrote under the question as to what was least helpful, "Everything was relevan"" and another wrote, "The program was very good." Data summarizing the responses from the four groups of participants to the question as to what types of experiences during their preservice program were least helpful in preparing them for the realities of teaching in a $21^{\text {st }}$ century public school is presented in Table 9.

A teacher must sustain their passion for teaching in order to embark on the hard work of change. When program graduates were asked what from the program helped sustain his/her passion for teaching, the most frequently mentioned item across all the years was the collaborative cohort model (41\%). One graduate enthusiastically wrote, "Being with a lot of people who felt the same passion and excitement for kids and learning. The fact that it was a tightly knit cohort was by far the biggest plus of the program. I LOVED my cohort." Another wrote, "The experience of talking, working, reflecting with other students helped me get into the mindset that it would be important to connect with colleagues in order to discuss, reflect, stay sane in the day to day practice." One graduate wrote, "Professional relationship, the cohort enables me to look toward my peers for support, advice. This is something I've valued and continue to do." Finally, another graduate wrote, "Being part of a cohort was awesome! It allowed me to learn how to work with other teachers and support them." Although $95 \%$ preservice teachers self-reported only sometimes participating in 
collaboration, $41 \%$ of them wrote about the importance of their cohort

collaboration as something that would sustain their passion for teaching.

Table 9

Comparison of Responses as to What were the Least Helpful Program Experiences*

\begin{tabular}{|c|c|c|c|c|c|}
\hline & $\begin{array}{l}\text { Total } \\
n=275(\%)\end{array}$ & $\begin{array}{c}\text { Group I } \\
1989-1994 \\
n=53\end{array}$ & $\begin{array}{c}\text { Group II } \\
1995-1998 \\
n=57\end{array}$ & $\begin{array}{c}\text { Group III } \\
1999-2001 \\
n-64\end{array}$ & $\begin{array}{c}\text { Group IV } \\
2002 \\
n=102\end{array}$ \\
\hline $\begin{array}{l}\text { Irrelevant methods/ } \\
\text { lack substance }\end{array}$ & $72(26 \%)$ & 17 & 21 & 23 & 18 \\
\hline $\begin{array}{l}\text { Theory w/o } \\
\text { Application }\end{array}$ & $28(10 \%)$ & 5 & 8 & 8 & 7 \\
\hline Technology & $25(9 \%)$ & 4 & 1 & 7 & 8 \\
\hline Multicultural Ed & $20(7 \%)$ & 6 & 2 & 4 & 10 \\
\hline $\begin{array}{l}\text { More classroom } \\
\text { Management }\end{array}$ & $17(6 \%)$ & 5 & 4 & 5 & 2 \\
\hline Reflection & $14(5 \%)$ & 0 & 2 & 4 & 10 \\
\hline $\begin{array}{l}\text { Out of date/ } \\
\text { Disengaged professors }\end{array}$ & $14(5 \%)$ & 6 & 4 & 2 & 5 \\
\hline $\begin{array}{l}\text { Inadequate ESL/ } \\
\text { Special Education }\end{array}$ & $8(3 \%)$ & 6 & 2 & 2 & 2 \\
\hline $\begin{array}{l}\text { Lack of communication } \\
\text { Guidance }\end{array}$ & $8(3 \%)$ & 0 & 2 & 3 & 4 \\
\hline $\begin{array}{l}\text { Nothing hindered/ } \\
\text { Left blank }\end{array}$ & $41(15 \%)$ & 6 & 5 & 12 & 18 \\
\hline
\end{tabular}

*Note. Taken from Survey Question 2: What types of experiences during the Graduate Teacher Education Program were least helpful in preparing you for the realities of teaching in a $21^{\text {st }}$ century public school?

Inspiring professors, cohort leaders, and mentor teachers who modeled a passion for teaching, learning, and kids were the next most frequent responses listed as to what from the program helped sustain the teachers' passion for teaching. Twenty three percent of teachers mentioned an inspiring professor. For example, a teacher 
wrote, "Passion of the instructors. They changed my outlook on the world and made me believe I could have a dramatic effect on my own students." Another teacher wrote, "My instructors celebrated teachers and teaching (as well as students and learning!) Everyday I wish my administrators could do this. Enthusiasm of instructors is KEY." Although, graduates from all the years mentioned inspiring leaders, the number varied between the different groups. Group II identified inspiring leaders the most frequently ( $42 \%$ ). Group IV members were not as impressed with their instructors. Only $9 \%$ of these preservice teachers identified inspiring professors or mentor teachers as helping to sustain their passion.

The rest of the responses about sustaining teachers' passion were distributed among many different elements of the program. Seven percent of participants identified reflection as the element of the program that helped sustain their passion. One graduate wrote, "Creativity and self reflection were encouraged and have maintained me through many crisis." Another wrote that she learned, "Reflective teaching, not to fear fresh ideas." Although field experience had been listed $55 \%$ of the time as the most beneficial element of the program, teachers listed their preservice field experience as helping to sustain their passion for teaching only $7 \%$ of the time. Four percent of the teachers identified learning best practices as helping them sustain their passion. Another 4\% listed motivational speakers and readings as helping sustain their passion. One teacher wrote, "Team building experiences, seminars, books, seminars, inspired me to make a difference in the classroom. Looking back on those experience helps rejuvenate me." Although $2 \%$ of participants complained the 
program's emphasis on social justice had been least helpful, another $3 \%$ identified it as something that helped sustain their passion for teaching.

Thirteen percent of the teachers from across the years argued that a program is not capable of sustaining or teaching passion. These teachers said it was their students and their personal drive that sustained their passion for teaching, not anything from the program. One teacher wrote that a program "teaches skills not passion." Another noted, "My inspiration comes from my students and myself." Yet another teacher commented, "My passion comes from within." One teacher wrote, "The program taught me to dislike education." However, the vast majority of the written responses were positive, revealing satisfaction with at least some aspects of their preservice experience. The data from the teachers' responses when asked what types of experiences during their preservice program helped sustain their passion for teaching has been summarized in Table 10 . 
Table 10

Responses as to Program Experiences That Sustain Their Passion for Teaching*

\begin{tabular}{|c|c|c|c|c|c|}
\hline & $\begin{array}{l}\text { Totals } \\
\mathrm{n}=275\end{array}$ & $\begin{array}{l}1989 / 1994 \\
\mathrm{n}=54\end{array}$ & $\begin{array}{l}1995-1998 \\
n=56\end{array}$ & $\begin{array}{l}1999-2001 \\
n=63\end{array}$ & $\begin{array}{l}2002 \\
n=102\end{array}$ \\
\hline $\begin{array}{l}\text { Cohort/ } \\
\text { Collaboration }\end{array}$ & $117(43 \%)$ & 18 & 18 & 22 & 41 \\
\hline $\begin{array}{l}\text { Inspiring } \\
\text { professors/mentors }\end{array}$ & rs $65(24 \%)$ & 14 & 24 & 18 & 9 \\
\hline $\begin{array}{l}\text { Not program/ } \\
\text { up to me/love of } k\end{array}$ & $\begin{array}{l}37(13 \%) \\
\text { kids }\end{array}$ & 11 & 18 & 9 & 10 \\
\hline Reflection & $19(7 \%)$ & 5 & 2 & 4 & 10 \\
\hline $\begin{array}{l}\text { Field } \\
\text { Experience }\end{array}$ & $19(7 \%)$ & 1 & 3 & 4 & 10 \\
\hline $\begin{array}{l}\text { Best Practices/ } \\
\text { Methods }\end{array}$ & $12(4 \%)$ & 0 & 3 & 3 & 4 \\
\hline $\begin{array}{l}\text { Classroom } \\
\text { Management }\end{array}$ & $12(4 \%)$ & 0 & 0 & 2 & 10 \\
\hline $\begin{array}{l}\text { Motivational } \\
\text { Speakers/readings }\end{array}$ & $10(4 \%)$ & 0 & 3 & 5 & 4 \\
\hline $\begin{array}{l}\text { Social justice / } \\
\text { Multicultural Ed }\end{array}$ & $9(4 \%)$ & 3 & 1 & 2 & 4 \\
\hline $\begin{array}{l}\text { Teaching/ } \\
\text { Learning theory }\end{array}$ & $6(2 \%)$ & 2 & 1 & 4 & 4 \\
\hline
\end{tabular}

*Note. Taken from Survey Question 3: What types of experiences during the graduate teacher education program do you feel have helped sustain your passion for teaching when faced with the day to day work in your school?

Survey question 4 asked program graduates to consider what about their

preservice program should be changed. The answers reflected teachers' recognition of the importance of some areas essential for the nurturing of change agents. However, the participants had very little consensus as to what needed changing. Their responses varied greatly within cohort years and across the various years. The most frequent 
suggestion, mentioned by $13 \%$ of participants advocated for aligning course work more directly with the field to make it more practical and hands-on. Related to this response were references to the need for professors either to be current teachers or to make sure they stay current with best practices and model good teaching strategies within their courses mentioned by $8 \%$ of the participants. A number of graduates $(6 \%)$ suggested improving the quality and quantity of communication and supervision in the field. Others (4\%) suggested teaching more authentic assessment strategies and differentiation. Five percent of the participants recommended that more specific content methods be added. Overall, there was very little consensus among graduates as to what needed to change.

Inservice teachers listed some suggestions not mentioned by preservice teachers. For example 15 inservice teachers $(8 \%)$ felt the program needed to have more explicit reading methods instruction. Some inservice teachers ( $4 \%$ ) suggested increasing the technology training. None of the current graduates felt lacking in technology experience. Six inservice teachers ( $3 \%$ ) recommended more math methods instruction. None of the current graduates mentioned math methods instruction needed changing. Finally, in reference to suggested changes in the program, a third year teacher wrote, "Not anything, I felt as prepared as possible to begin teaching."

Group IV, preservice teachers, suggested a number of changes not identified by inservice teachers. Some of their suggestions may reflect some organizational problems unique to that year's cohorts. They participated in the program during a 
particularly difficult time with threatened teacher strike and a shortened school year due to a statewide funding crisis. Thinteen percent of the preservice teachers suggested that the program needed to work on making the program more organized and increase the cohort leaders' communication. Still in process of completing their student teaching, $5 \%$ of the preservice teachers suggested that the program should reduce the amount of course work during student teaching.

Fifteen teachers (5\%) from across the years of the program requested more specialized methods classes. The desire to provide methods that are more specialized was part of the impetus for creating a separate science math cohort. A special grant from the National Science Foundation during 2002 allowed for a special focus cohort of only science/ math preservice teachers. One of the members of that cohort wrote, "Don't separate cohort by subject area. [There] is value in people from different disciplines working together and learning strategies together." The third year of a separate science/math cohort will start in the summer of 2004 . Table 11 shows the Data from responses to the question about what should be changed in the program. 
Table 11

Comparison of Responses as to Recommended Program Changes*

\begin{tabular}{|c|c|c|c|c|c|}
\hline & $\begin{array}{l}\text { Totals } \\
\mathrm{n}=275(\%)\end{array}$ & $\begin{array}{c}\text { Group I } \\
1989 / 1994 \\
n=54\end{array}$ & $\begin{array}{l}\text { Group II } \\
1995-1998 \\
n=56\end{array}$ & $\begin{array}{l}\text { Group III } \\
1999-2001 \\
n-63\end{array}$ & $\begin{array}{c}\text { Group IV } \\
2002 \\
n=102\end{array}$ \\
\hline $\begin{array}{l}\text { More practical/ } \\
\text { Hands-on/ field connectio }\end{array}$ & $38(14 \%)$ & 12 & 12 & 6 & 8 \\
\hline $\begin{array}{l}\text { Professors need } \\
\text { to be current/model } \\
\text { best practices }\end{array}$ & $22(8 \%)$ & 7 & 6 & 2 & 7 \\
\hline $\begin{array}{l}\text { More/better } \\
\text { field supervision }\end{array}$ & $17(6 \%)$ & 1 & 4 & 1 & 1 \\
\hline $\begin{array}{l}\text { More specific } \\
\text { methods }\end{array}$ & $15(5 \%)$ & 1 & 6 & 1 & 7 \\
\hline $\begin{array}{l}\text { More reading methods } \\
\text { instruction }\end{array}$ & $15(5 \%)$ & 0 & 4 & 3 & 8 \\
\hline $\begin{array}{l}\text { More varied field } \\
\text { experience }\end{array}$ & $14(5 \%)$ & 6 & 3 & 4 & 0 \\
\hline $\begin{array}{l}\text { Classroom } \\
\text { management } \\
\text { while in field }\end{array}$ & $14(5 \%)$ & 3 & 4 & 5 & 0 \\
\hline $\begin{array}{l}\text { More on } \\
\text { assessment }\end{array}$ & $12(4 \%)$ & 4 & 2 & 3 & 3 \\
\hline Job hunt help & $11(4 \%)$ & $i$ & 1 & 2 & 7 \\
\hline $\begin{array}{l}\text { Prepare to work with } \\
\text { administrators/parents/ } \\
\text { community resources }\end{array}$ & $9(3 \%)$ & 0 & 4 & 5 & 0 \\
\hline $\begin{array}{l}\text { More technology } \\
\text { instruction }\end{array}$ & $8(3 \%)$ & 3 & 3 & 2 & 0 \\
\hline $\begin{array}{l}\text { Less technology } \\
\text { Instruction }\end{array}$ & $2($ less than $1 \%)$ & 6) 0 & 0 & $!$ & 1 \\
\hline More flexibility & $8(3 \%)$ & 6 & 0 & 1 & 1 \\
\hline $\begin{array}{l}\text { More care in } \\
\text { placements/oversight }\end{array}$ & $8(3 \%)$ & 0 & 2 & 6 & 8 \\
\hline
\end{tabular}


Table 11

Comparison of Responses as to Recommended Program Changes* (continued)

\begin{tabular}{|c|c|c|c|c|c|}
\hline & $\begin{array}{l}\text { Totals } \\
\mathrm{n}=275(\%)\end{array}$ & $\begin{array}{c}\text { Group I } \\
1989 / 1994 \\
n=54\end{array}$ & $\begin{array}{c}\text { Group II } \\
1995-1998 \\
n=56\end{array}$ & $\begin{array}{c}\text { Group III } \\
1999-2001 \\
\text { n-63 }\end{array}$ & $\begin{array}{c}\text { Group IV } \\
2002 \\
n=102\end{array}$ \\
\hline $\begin{array}{l}\text { More ELL } \\
\text { training }\end{array}$ & $7(3 \%)$ & 1 & 0 & 4 & 0 \\
\hline $\begin{array}{l}\text { More math methods } \\
\text { instruction }\end{array}$ & $6(2 \%)$ & 2 & 0 & 4 & 0 \\
\hline More rigor & $6(2 \%)$ & 1 & 3 & 1 & 1 \\
\hline Differentiation & $6(2 \%)$ & 1 & 4 & 2 & 1 \\
\hline $\begin{array}{l}\text { Less course work } \\
\text { while student teaching }\end{array}$ & $6(2 \%)$ & 1 & 0 & 0 & 5 \\
\hline $\begin{array}{l}\text { Cohorts by } \\
\text { grade level clusters }\end{array}$ & $6(2 \%)$ & 0 & 3 & 2 & 1 \\
\hline $\begin{array}{l}\text { Teach organizational } \\
\text { skills }\end{array}$ & $6(2 \%)$ & 0 & 0 & 2 & 4 \\
\hline $\begin{array}{l}\text { Bring in recent graduates } \\
\text { to share insights }\end{array}$ & $6(2 \%)$ & 0 & 3 & 2 & 1 \\
\hline $\begin{array}{l}\text { Less emphasis on } \\
\text { diversity/social justice }\end{array}$ & $5(2 \%)$ & 2 & 0 & 2 & 1 \\
\hline $\begin{array}{l}\text { More emphasis on } \\
\text { diversity/social justice }\end{array}$ & $4(1 \%)$ & 2 & 0 & 1 & 1 \\
\hline $\begin{array}{l}\text { More emphasis on } \\
\text { standards }\end{array}$ & $4(1 \%)$ & 2 & 2 & 0 & 0 \\
\hline $\begin{array}{l}\text { Merge masters/ } \\
\text { licensure }\end{array}$ & $4(1 \%)$ & 1 & 3 & 0 & 1 \\
\hline Part time option & $4(1 \%)$ & 0 & 0 & 3 & 1 \\
\hline Less reflection & $3(1 \%)$ & 1 & 0 & $\mathbb{1}$ & 1 \\
\hline More reflection & $3(1 \%)$ & 0 & 0 & 1 & 2 \\
\hline
\end{tabular}

* Note. Taken from Survey Question 4: What would you change in the program? 
Summary of Findings from Open-ended Responses

Data from the open-ended responses were clustered by the three subcategories of teacher as change agent: competence, learner, and sense of agency. Teachers wrote about the importance of learning best practices, effective methods, classroom management skills and learning theory, all elements of competent teachers. A large number of participants identified the cohort model, collaborative learning, technology, and reflection as what helped sustain their passion for teaching, indicating teachers who saw collaborative, lifelong learning as important elements of their professional lives. Finally, teachers wrote about their students sustaining their passion to teach, the importance of multicultural education, social justice, the desire to learn more about differentiation, meeting the needs of English Language Leamers, and the special needs their students. These responses reflected teachers who maintained a strong sense of agency for their students.

Interviews and Portfolio Review

The findings from the six interviews and portfolios of teachers pursuing their continuing teacher license (CTL) revealed similar perspectives to those reflected in the written survey responses from the larger pool. Participants were asked the same questions on the open-ended section of the survey: What was the most beneficial, least helpful, what sustained their passion to teach, and finally what would they change about their preservice program.

The researcher analyzed the data from the interview transcripts and the professional portfolios using a "template analysis strategy" as described by Marshall 
and Rossman (1999). Data were categorized under three headings using the three main components of the construct of teacher as change agent: (a) competence, (b) learner, and (c) agency.

\section{Evidence of Teacher Competence}

Frequently the teacher's competence was evident implicitly through their dialogue and artifacts in their portfolios. For example, the middle school social studies teacher, Mike described the unit he had designed in which he was connecting current events with history using role-plays and simulations. Mike was helping his students see the relevance of studying history to their own lives. It was apparent that he not only understood best practices for middle school social studies, but he was also implementing them in his classroom. As he described how he set up his classroom community, it was evident that Mike had a clear understanding of young adolescents' need for choice. Mike described how he taught his students to take the locus of control. Mike respected his students and made it a point to build positive relationships within his middle school classroom, keys to successful teaching of adolescents.

Evidence of competence emerged from what the teachers identified as the most beneficial aspects of their preservice programs. For instance, when talking about her preservice experience, the high school science teacher, Molly praised her mentor teacher for modeling project-based learning in a high school biology classroom. The high school math teacher, Carol acknowledged the excellent modeling of her mentor teacher in his ability to meet the developmental needs of adolescents, stating that her mentor teacher was excellent at building relationships with students and their families. 
The intermediate grade teacher, Jan also talked about the modeling of her mentor teacher, stating that she "really had a handle on the age group."

In the portfolios, copies of evaluations from administrators demonstrated the high level of competence of these relatively new teachers. One administrator wrote about the intermediate teacher, "Everything about her teaching demonstrates that "Jan" is a highly professional teacher." The administrator went on to identify the Jan's strengths in curriculum design, differentiated lessons, and assessment. Another administrator wrote about "Ann", one of the first grade teachers:

"Ann" has exceeded all district performance standards... Not only does she have a heart for teaching but she is also a skilled educator who is constantly setting higher goals to stimulate continued growth. She is a consummate professional in everything she does...Ann is a superior educator.

Her continuing teaching license professor's evaluation concurred:

Ann is a knowledgeable and highly skilled primary teacher. Her effort, commitment, and willingness to learn are evident in every aspect of her classroom and her teaching. Her students like and respect her, but more important, they are leaming rapidly and deeply, with much enjoyment and pride. In every respect, she is outstanding.

Despite having taught for only a few years, all but one of the interviewees

mentioned taking a leadership role in training other teachers, conducting workshops in literacy, math, science, English language learners, or classroom management for their staffs.

Evidence of Lifelong Learning

Commitment to lifelong leaming was obvious in the six teachers interviewed. All six participants mentioned workshops, conferences, and professional readings they 
had already pursued in their fields to enhance their competence. Their portfolios included lengthy lists of professional learning completed, as well as their goals for their next areas of development. They recognized that learning does not stop when one received a teaching license; rather they saw that being a learner as one of the fundamental roles of teachers. Jan wrote in her portfolio," I learn and acquire knowledge through experiences alongside my students as we joumey together towards growth in our understanding of ourselves and the world, each in our own perspective stage of development." Jan explained eloquently her understanding and appreciation for learning as part of her responsibility as a teacher.

Risk-taking was evident in most of the six participants through their descriptions of day-to-day classroom experiences. For instance, Mike, the middle school teacher talked about his choice not to use assigned seats and why he allowed students to eat in his classroom. Mike also mentioned taking on a special program for at-risk students in his school, children other teachers had been unable to reach.

Another exemplar of risk taking was Ann, a suburban first grade teacher willingness to look vulnerable with her peers. Ann explained, "I'm willing to say I don't know this and I need help with this." Ann also mentioned how she welcomed parents into her room and experimented with new approaches, both requiring risk taking. Parental thank you letters included in the portfolio indicated how successful her experiments have been. Melissa, the primary grade teacher teaching in inner city, took a risk when she organized an overnight camping trip with her poverty level youngsters and their families, driving three hours in a bus to study a different ecosystem. Carol, the high 
school math teacher also demonstrated risk taking when she initiated numerous conversations and emails with parents demanding high expectations from students who had never been challenged before. Finally, Molly, the high school science teacher commented on her comfort level with risk taking, "When things start to feel too comfortable, that is a sign that I should be taking on some new responsibility or branching out in to new course areas." In order to keep learning and growing professionally, it is necessary to take some risks. These teachers accepted risk taking, as part of their job as they strove to meet the complex needs of their students.

Professional collaboration is another dimension of teachers who are lifelong learners. The findings for Sub-Question 7 are embedded within the findings on collaboration.

\section{Sub-Question 7.}

How do the perceptions of teachers-as-change agents differ based on whether they are working in a school that has established a professional community with shared norms of collaboration?

Collaboration was addressed in the scale and initiated by teachers in their responses to the survey, interviews, and in their portfolios. However, the specific question as to the effects of a professional community with shared norms of collaboration on a teacher's ability to be a teacher change agent was not addressed directly in this study. Through the frequent references to peer collaboration by all the interviewees, it is possible to infer that the six teachers interviewed worked in schools with a shared norm of collaboration. Collected data was inadequate to draw any 
conclusions about the extent a school's norms were able to influence a teacher's

openness to change.

Collaboration was evident at the elementary, middle, and high school levels.

All six of the participants practiced collaboration, an emphasis of the teacher

preparation program. When asked what was the most beneficial part of the program,

Melissa stated, "I was taught how to write unit plans and to do that collaboratively. I

think that has been invaluable." Melissa shared that she currently writes units with her

first grade team and that they reflect together afterwards, as modeled in her cohort.

Melissa was also part of her school's Reading Success Network, which she described

as:

A group of teachers from different grade levels learning how to use data more successfully, quickly, and relevantly. We are learning to have very brief but effective dialogues with colleagues about reading data, the end results being that the staff would be using assessment data to formulate the best possible levels of instruction. It builds in a common language for a discussion.

This type of professional collaboration is precisely the kind described in the studies of successful school reform (Elmore, 1995; Little, 1982; Louis \& Marks, 1998).

Ann spent a substantial amount of the interview time lamenting her staff's resistance to collaboration. She explained her mission on the literacy team had been to help her staff open up and not be afraid to be vulnerable. Ann described dressing up as the literacy "fairy" complete with magic wand in hopes of getting her staff to relax and share:

We are not teaching them (other staff), we're trying to open the conversations ... We are learning to share, but they can't let you know that they don't know ... there's nothing wrong with saying I don't know in education ... I think 
teachers are each other's greatest resource ... You need to have open conversations in a safe environment and be able to pool that information.

In her portfolio, Ann wrote about the importance of including parents as part of the team for kids, as well, "I want to create a synergetic environment where diverse ideas are honored and valued and the effect is greater than the sum of the individual effects." Again her openness to collaboration aligns with the research on school change.

Jan was equally involved in being part of a collaborative professional community. She coordinated parent volunteers for her whole school, was on site council, and lead multi-grade level discussions. Although only in her third year of teaching, Jan had already volunteered as a science trainer, math trainer, and as part of the interview committee for new hires. Additionally, Jan was running the school's wildlife steward program.

Mike talked about collaborative efforts in his first school experience. Mike expressed how fortunate he felt during his first three years teaching to have taught in a school with joint planning in which his team routinely talked about students' needs. Mike also talked about his current school, where he had learned to embrace parent communication and recognize the parent role on the learning team. Mike explained, "All parents have been helpful and supportive." He also appreciated being a part of his current school's team; "I am constantly going to other language arts teachers looking for ways to present material and aids in order to give the students the opportunity to be successful in language arts." Mike understood that teaching does not have to be as isolating as the profession described by Lortie (1975). 
High schools are not known traditionally for their high levels of

collaboration. However, both of the high school teachers interviewed emphasized collaboration in their interviews and portfolio essays. Molly talked about how much she valued working with the science team. She also mentioned participation in an optional critical friends group and in a mentoring program. Molly commented that the teacher preparation program's cohort system really was about "teaching us collaboration." Carol talked about planning with colleagues, her volunteer work at speech tournaments, as department chair, and her volunteer participation in "student study teams" in which teachers got together to brainstorm ways to help troubled youth. In addition, Carol had helped her district with Praxis test review, worked with colleagues to redesign the math curriculum to adjust from quarters to trimester schedule, and worked on a panel to develop performance based assessments to use for Proficiency Based Admission Standards System (PASS) requirements for entrance into the state universities.

Each of the participants discussed how they established a learning community within their classrooms. Melissa worked hard to develop deep relationships with her students. Melissa invited her students to class picnics during the summer, sent postcards to all the students, and invited them to her home and to excursions around town. Ann talked extensively about establishing her classroom community, "I create a classroom climate conducive to learning for all the children. I encourage students to rally around and help other children feel accepted, comfortable, and successful." This was also evident from the numerous thank you notes written by parents and students 
included in her portfolio. For example, one note, written in six-year-old handwriting, read, "Thank you for helping me get smart. Love, Adam." Another note from a parent volunteer stated, "You really made each child feel so special today. It made me teary. I am lucky to have time to come into the classroom and feel very privileged to see how they have all grown over the school year." The parent note reflected Ann's success at forming a welcoming learning community within her classroom.

Jan shared how her entire school was "such a safe place for our kids." She explained that her students came from sad homes where they dreaded vacations. Jan mentioned how she had written postcards to all her students during the summer welcoming them to her class.

Mike described how he consciously worked to build an emotionally safe learning community in his middle school classroom. Mike gave students' choice of seating arrangement, assignment due dates, class rules, and curriculum negotiation. He explained:

If students don't trust the classroom or feel welcome, then little if any valuable learning will take place. I understand that students know what teachers are interested and truly care for them and will react to these conditions.

Giving students voice within his room was an important part of Mike's community building.

Community building can be more of a challenge at high school level, where typically a teacher has students for only one short period a day. Both high school 
teachers discussed the value they placed on building classroom community. Molly explained:

One of the big challenges in teaching is to set up the classroom so that students feel like they have some ownership in what goes on ... If I have a feeling of "we are in this together" in my classroom then classroom "management" becomes a non issue.

Molly demonstrated her openness to bringing students into the learning process as equal partners.

Carol also described how she established a learning community in her math room. For example, she set up an environment in which it was okay to take risks by giving candy to anyone who caught her making a mistake. Carol also gave candy to students who took risks by sharing in front of the class. She wanted her students to realize "We learn more when we learn together."

Each of the participants expressed enthusiasm for the subject matter that they taught. They personalized curriculum to make it continually interesting to themselves as the teacher and to their students. Melissa wrote in her portfolio, "I am constantly reworking aspects of my teaching to maximize our time and so that there is enough variety that the children don't get bored and neither do I. I very seldom re-teach the same material in the very same way." Carol wrote, "I have always loved math." Ann shared her perspective in the classroom, "Being a student is a constant reminder that knowledge is difficult to come by and it becomes more meaningful and more precious when you have to work very hard to obtain it." Ann expressed her personal satisfaction at facing the challenges inherent in learning something new and how she shared that with her young students. 
All six teachers brought personal relevance to their work. They cared deeply about their subjects as well as their students. During the interview, Molly shared that she was always thinking about teaching. For example, while in San Francisco on vacation, she visited the Exploratorium to collect ideas for her science classroom. Molly observed, "I am so fortunate that my professional activities never really stop. I have support at home to continue learning and growing in my field." Jan also discussed her love of teaching science, "I would like to continue my research on bats in Oregon, which is a personal passion that I bring to the classroom through our science block."

Reflection was an obvious part of all these teachers' professional lives. Ann noted her cohort leader's emphasis on reflection during the program, "Her whole focus was reflection and diversity. That was her theme ... Learning to ask a good question is teaching." Jan, who had the same cohort leader, shared that her cohort leader "really encouraged me to think deeper." She elaborated, "You need to start questioning things you've established ... you need to think about why exactly am I doing them, because otherwise you're going to get really bad habits." Finally, Jan insisted, "You need to reflect. This is very important." Carol did complain that the program's course in reflective practice did not work well when it was taught in the first quarter, "I don't see a whole lot of value to reflection on something that I have only experienced in a purely academic sense." Typically, the course was taught close to the end of the four-quarter program. 
The entire continuing teacher licensure program in which teachers prepare their professional portfolios was a reflective process. The six participants had spent a year and a half writing large portfolios reflecting on their practice. The collaboration they described, such as critical friends groups, numerous workshops, and experimentation, as well as internal questioning of their practice, were all-important elements of being reflective practitioners who continued to learn and develop as professionals.

Evidence of a Teacher's Sense of Agency

According to the researcher's operational definition, a teacher with a sense of agency has a strong self-efficacy, believes they can make a difference and is willing to personally change to help their students. All six of the interviewees were teachers with a strong self-efficiency. Their openness to sharing their passion, constant questioning of their practice, and willingness to be vulnerable, all reflected people who have a strong self-efficiency. Mike described his intensity and passion as a teacher:

Anyone can study up on a topic, but it takes skill and lots of practice, and to some extent natural ability, as well as a love of students and learning to teach... I like building positive relationships with students. I think my strongest point is my ability to relate and understand where students are coming from. I think I am obsessed, a stressed out seeker of perfection, father, husband, and school teaching fanatic.

Mike's enthusiasm and deep caring for his students resonated throughout his writing.

When reflecting on the program, Carol commented, "I think, if $I$ could add anything to the program it would be, to have a thorough knowledge of self." She 
recognized the importance of understanding one's self as a teacher. Carol went on to make an even more astute observation, "So much of the whole program has to do with making sure our heart is in the right place, and you can't. I't's difficult to measure and even more difficult to train someone to have their heart in the right place."

In the interview, Jan expressed her passion for teaching, "You are doing it for the right reasons because you love kids and you love learning. It just does something for your spirit. You just take a deep breath and know this is right, this feels right, even though it is hard." Jan attributed her own self-confidence to her preservice program:

I had great cohort leaders. I had a great mentor teacher. As hard as it was, I was prepared. I have a sense of confidence that I have the resources I need to do a great job and to be a great teacher.

Jan demonstrated a strong self-efficacy.

In both the interviews and personal essays, the teachers expressed their determination, and sense of empowerment to truly make a difference in the lives of their students. Ann shared the motivation behind her missionary zeal:

My son, he was not the kind of kid that was going to learn every day in the same way. That is why I was going to go try to save kids like him, that's what my focus is.

Ann wanted to make sure students in her classes needs were met, more matter how challenging.

At two different times in the interview Mike said, "You can make the difference here. If you can build those connections, I can get so much out of the kids." Mike talked about the influence of one of his professors in the program, "Ben [an alias] always said, 'it's kind of about the kids.' Ben had the attitude installed in us that 
you are there for the kids. When it comes down to it, how is this going to be good for the kids?" Mike believed Ben's words helped to sustain his passion. Sharing his own sense of empowerment to influence his students in positive ways, Mike wrote in his portfolio:

I get extremely involved in my students' welfare. I would receive great satisfaction along with terrible lows based on how they did academically and socially. I use this relationship to get a student to stop skipping school, to do homework, to be patient and give me a chance to explain something that is difficult and time consuming.

Mike also wrote about how he helped students build on their strengths, "I have had to work at getting students to realize how they learn best. I have had to find new ways of reaching students in an effort to get them to understand the material at hand." Again, Mike shared his determination and flexibility to help all his students succeed, "I allow students the freedom to show me that they learned any way that they can, be it verbal tests, written test, poster board, skit, pair share, etc." Mike described his studentcentered classroom where he individualized the curriculum to meet each of his student's needs.

Molly discussed the same professor's influence on her teaching, "Ben teaches how to feel respective to kids." Molly described her own dedication to her students and her work:

I am very committed to my job and to my students. I spend an average of ten hours at the school on each school day, then usually bring some work home... I also make it a point to attend sports, plays, music and dance events and any other activities that my students might be involved in. 
Molly shared how she has had to modify her time with a new baby at home and how hard that had been.

In a personal essay in her portfolio, Molly expressed her concerns about teaching in an affluent high school with children who were part of the "haves" in a society increasingly divided and unequal. She wrote, "Everyone who works in public education should at least be aware of these inequities and should work to eliminate inequitable practices from their own work." Molly expressed her belief that part of her job, as an educator was to teach her students who were growing up with privilege to help work for change:

I find that is it more helpful to inspire my students to be instigators of change and thoughtfulness than to make them feel guilty for growing up in an environment of privilege... Still sometimes I do feel the need to gently remind student of this privilege when they are being insensitive to people who do not have what they do.

In addition to feeling strongly about helping her students work for change, Molly expressed her willingness to work for change within her school. For example, Molly wrote about her frustration over a discussion of a school reform at her school that required revamping daily schedule. She mentioned taking a class on educational reform that involved reworking her curriculum to fit more closely the proposed school reform ideas. Finally, Molly wrote passionately about her desire to continue to be open:

Many things about my teaching will take effort to change. I cannot just sit back passively and expect the rest of my life to dictate how I will change. I think this is the mistake that some career teachers make. I will continue to grow as a teacher if I continue to reflect on what I am doing, seek out alternative perspectives, and go out on a limb occasionally to try something new. 
After 3 years of teaching science to disenfranchised teenagers, Molly had not lost her strong sense of missionary zeal.

Melissa expressed a similar sense of agency in her work. She explained why she had chosen to stay at her school despite her dissatisfaction with the newly installed less effective mandated reading program:

My goal is to figure out how to take that stuff and make it an acceptable reading program in my classroom, because you know I always swore I would never use that stuff either but you know I just can't say, "I'm sorry you kids no longer are going to have me. I am going to move on to a school that doesn't have it. You know that's not right.

Melissa shared her distress that other teachers transferred out of her Title I School over the summer in protest. She felt that if she transferred she would have deserted the students who needed her the most. Melissa explained, "Sometimes you have to like take your philosophy, set it aside a little bit, not lose it, and ... try to fix what you are doing but G-d those kids don't deserve you to walk out on them because you aren't doing whole language." Continuing a discussion of the reading wars, Melissa explained that even though she believed in whole language, she used whatever it took to meet her students' needs, "What's wrong with meeting out here in the middle? We always say no one learns the same and yet educators are the first to say this is the only way to do something."

Melissa's passion and willingness to do what it takes to meet her students' needs was reinforced in her personal essay:

All children can learn. That means that given the right amount of time, the right circumstance, the right support, and the right 
learning method, all children can reach the goals that have been set for them. The children entering my room are already behind and so it continues to be a game of catch up and a constant search for a way to move them ahead faster.

She went on to explain how she tutored her struggling readers two afternoon s a week and was able to see her efforts pay off in students' growth. It was obvious that for Melissa, her students came first.

Carol reflected that same dedication and love for her students. When describing her lowest track math class, Carol confessed:

Those kids drive me crazy, their behavior is the worst, as far as management, those are the kids that you love. Those are the kids that try to teach you how to $\mathrm{C}$ walk. You know? Even though there is not a coolness gene in me...I really enjoy the kids.

Understanding that part of her job was to figure out how to make math engaging to her students Carol pondered, "I have discovered ways to make math more interesting. But how can they be developed and combined with other forms of motivation to really engage more of the kids?" Carol had continued to change her practice to better meet her students' needs by increasing her use of modeling applications and explicating sharing her math thinking with her students. Carol concluded, "I want my students to succeed in mathematics and feel joy in their successes. Whenever they do, I will know I have been a success."

Jan also shared her passion for her students' welfare. Jan believed that building relationships with her students and families helped her to sustain passion:

Connecting with your kids and your families, you have to have a vested interest, ... it makes it easier because you have a heart with these kids, and it's easier to help them through their struggles. If 
you weren't connected to them, you would just be frustrated all the time

.... It is really a privilege to be able to see them changing.

She wrote in her portfolio, "I see a strong link between the success of my students and the improvements I am trying to make." In both the interview and her portfolio, Jan expressed a desire to leam the native languages of her students. She explained that if she learned their languages they would know, "I value who they are and want them to succeed and that I honor them for who they are." Jan shared, "Day after day I enter my classroom with the youthful optimism that I will make a difference and that my life's work will have meaning and sustenance."

Ann also shared her passion for her first grade students. Ann reflected on the program's emphasis on meeting all students' needs and how that message influenced her interactions with a new boy who joined her first grade classroom halfway through the year speaking no English:

The thing that always sticks out in my mind is the diversity piece. They really hit hard on that .... My cohort leader made sure that we understood other children's differences, how to try to differentiate those needs. It took me extra time to spend trying to figure out how am I going to help this child, not just push him off to side, and say I hope he learns something this year, but to really work with him and get resources to pull in.

Ann's passion and sense of agency seep through her words as she repeated the same mantra shared by all the participants; teaching is about meeting the needs of each student. Ann credited her cohort leader for "telling us that we're going to have to go back and go into that deep part of your heart on why you wanted to do this." Ann shared how she has learned to cope when the politics frustrated her: 
You come back to the passion, and that heart that you put in to teaching, the reasons why you are even doing it to sustain you, because the other stuff will kick you down. It will kick you down.

Ann's passion exuded in both her interview and in her personal essays. She

wrote in her "Who Am I Essay":

I am wildy, madly, passionately in love with teaching and working with children .... I want to be influential in helping children to fulfill their potential and their dreams and in shaping children's early attitudes about school and learning. It is my quest to empower children with ability to become successful, confident, independent lifelong learners.

Ann shared her belief in the power of embracing the personal gifts of each child. She recognized that even children as young as six year old are not empty slates:

One core belief is that children come to my class with a wealth of experiences and knowledge gained through out their lives. Their knowledge and experiences are valuable resources to draw upon as I guide them to new discoveries and knowledge. I believe that children have the power within themselves to learn and progress toward their maximum potential.

These words were not spoken by a naive young person, but a very competent middleaged mother of four, who had taught first grade for three years:

I am an idealist and I don't apologize for it. I understand the realities of politics, personnel, performance, pupils, parents, and the public. I focus on situations and issues that I can control and try not to spend physical or emotional energy on what I can't control.

Ann recognized that excellent teaching takes hard work, a willingness to reflect on one's practice, and continue to evolve, ${ }^{6 T}$ The dynamic of each class demands that I probe and ask the same hard questions over again. The ensuring answers come as we struggle together and shape a curriculum together to meet the needs of an ever 
changing community of learners." In setting up her classroom as a leaming community Ann established an environment in which students learned that they were capable of the hard work of leaming. Ann worked diligently to make her classroom a place of deep respect for each other and for the learning process:

My students care about each other and treat one another with kindness and respect. They are learning how to do a very "hard thing" - to solve social problems using respectful words. I am pleased they chose the song entitled "Peace is the world smiling" as their favorite song of the year. If they can do the hardest thing possible known to man - bring peace to the world - then I feel that I can be considered a competent teacher!

The six interview discussions and the professional portfolios were rich with evidence of teachers who were competent, lifelong learners, who held a strong sense of agency. All six teachers radiated a passion for teaching, love and dedication to their students.

\section{Summary of the Overall Findings}

The findings from the scales, open-ended survey questions, the interviews, and portfolio analysis all showed that graduates held some characteristics of teachers open to change. The data from the scales revealed a moderate level of self-reporting of behaviors indicative of teachers open to change. Reflection, collaboration, and caring for the well being of their students were frequently reported behaviors of the participants. Areas of lesser involvement included embracing families and communities in the learning environment, and the inclusion of student voice in curriculum design. Although they identified some areas of collaboration, inviting colleagues into their classroom and discussing their practices with their peers were not routine behaviors for inservice or preservice teachers. The data did not reveal 
statistically significant variations in the responses of teachers across the years for any characteristics of teachers open to change.

The program graduates' responses to the open-ended questions at the end of the survey reflected teachers who appreciated experiential learning, collaboration, and working with their students. Field experience, the cohort model, inspirational leaders were important benefits of the program to most participants. Unlike the findings from the scale, there were some variations in the open-ended responses across the years. Teachers who had been out in the field the longest were more positive about the reflection and methods instruction than some of the later groups. The veteran teachers had more concerns about their technology training and lack of preparation for special needs students and English language learners. Suggestions for change covered a wide range of topics. In particular, teachers requested more experiential hands-on opportunities to apply theory to practice.

The interviewees' responses and their extensive writing in their CTL portfolios provided abundant evidence that all six teachers emulated characteristics of teachers open to change and in fact were already working collaboratively within their schools for positive change for the good of their students. Although these six teachers taught in quite diverse settings, came into the program at different stages of their lives and had a variety of reasons for going into teaching, clear similarities were noted in their responses. The interviews and professional portfolio analysis provided the researcher with the opportunity to examine more deeply the perspectives of six teachers who had completed the program within the last few years. This more in-depth analysis revealed 
teachers who strongly displayed all the dimensions of teacher change agents as defined by the researcher. 


\section{CHAPTER V}

\section{DISCUSSION}

I see myself as a willow tree, willing to blow in the wind in order to stay grounded in my beliefs, versus an oak tree that refused to give and is often blown over in the ensuring storm. Unlike the caterpillar going through an unexpected metamorphosis, Ihope that I do not come to an end of my metamorphosis. I feel that as a person and a teacher I can never stop evolving. When I fail to continue to change, I hope that I have to wherewithal to leave the profession. $\left(4^{\text {th }}\right.$ year teacher, program graduate from Group III)

The above quote captures the teacher's passion, determination, and openness to change. Though this teacher's openness may not be a direct consequence of his teacher preparation program, elements of the program helped build the foundational "roots" upon which this teacher could flourish.

\section{Summary of the Study}

This study examined alumni of a graduate teacher education program to determine if they exhibited characteristics of teacher change agents. Researchers have identified the key characteristics of teachers involved in successful implementation of school reform as: teacher collaboration, openness to continuous growth and learning, reflective analysis, and a teacher's sense of agency (Elmore, 1995; Little, 1982; Louis \& Marks, 1998; Marks \& Louis, 1997). The scope of this study was to examine what preparation was required for teachers to be open to change in whatever direction is 
necessary to meet the educational needs of their students, not to define specific changes. As stated in the first chapter the delimitation of the study was that it focused only on the program's ability to create teacher change agents not on the program's overall goals and purposes. However, in the process of completing the study, program graduates shared some valuable information about overall program design (seeTable 12). Certain components such as methods courses, multicultural education and classroom management were reported in both categories indicating a lack of consensus among graduates.

Table 12

Program Components Graduates Identified as Most Beneficial and Least Helpful

Most Beneficial

- Field Experience $\quad 56 \%$

- Best Practices/ 28\% Methods

- Cohort model 25\% Collaboration

- Classroom Management

- Mentors

- Multicultural Ed
Least Helpful

- Irrelevant Methods 26\%

- Theory w/o 13\% application

- Technology 9\%

- Multicultural Ed $7 \%$

- Classroom 6\% Management

- Reflection $\quad 5 \%$

Four measurement tools were used to explore the research questions. The researcher designed the Teacher Adaptability Measurement Scale (TAMS), which was completed by 282 participants. The same graduates responded in writing to a set of open-ended survey questions. In addition, six participants were purposively selected and interviewed extensively. Their professional portfolios developed as a part of the 
state continuing teaching licensure requirement were examined for a more in-depth view as to whom they were as professional educators.

In this study, the specific research question examined was, "What influence does a teacher education program have on the development of future teacher change agents?" The study's findings revealed behaviors indicative of teachers open to change were evident in program graduates. Results also showed which attributes of teachers open to change were more or less strongly represented in program graduates. Although, the research design did not allow for a determination of a direct causal relationship between teachers' current perception of themselves as change agents and their preservice program, the information is useful for program faculty in considering program redesign. Program graduates reported areas of strength and weakness (see Table 13).

Table 13

Program Graduates Areas of Strengths and Weakness

Areas of Strength

Graduates:

- Believe in their students and value knowing their students well

- Seek consultation over concerns about the emotional and academic well-being of their students

- Reflect on their practice process

- Establishing democratically run classrooms

\section{Areas of Weakness}

Graduates are not:

- Inviting student voices into their curriculum design

- Inviting colleagues into their rooms to observe their practice

- Embracing families and communities in the learning 
Discussion of Research Questions

In order to answer the research umbrella question, a series of seven subquestions were developed. Discussions of each sub-question's findings follow.

Discussion of Sub-Question 1.

In what ways do program graduates perceive themselves as change agents?

Four measurement tools were used to examine this question indirectly. The TAMS was designed to look at how teachers self-reported themselves participating in behaviors that reflected the characteristics of teachers open to change. The quantitative data from the scale reflected moderately high levels of behaviors indicative of a teacher open to change. In particular, reflective and collaborative skills were frequently reported. These findings were significant in that numerous studies have documented the importance of reflection and collaboration as key characteristics of teachers in schools with successful school change (Fullan \& Hargreaves, 1992; Little 1982; Zeichner \& Liston, 1987).

In the response to the open-ended survey question, "What would you change in the program?" one graduate did write that the program needed to teach "how to become an educational activist," a statement indicative of a teacher who values activism. All of the six interviewees discussed their active involvement in their school's reform efforts and wrote in their portfolios about their willingness to continue to change and grow to meet their students' needs. The findings from the six interviewees provided strong evidence that the attributes of teachers open to change are easily recognizable in some graduates. 
Discussion of Sub-Question 2.

What is the effect of the teacher education program on graduates' ability to be collaborative team players?

Program graduates' participation in professional collaboration was revealed in the study's findings. On the scale, graduates reported very high levels of collaboration in certain areas such as seeking consultation for the emotional and academic well being of their students. Program graduates frequently listed collaboration and the cohort model as important contributors to their ability to sustain passion for teaching, as well as one of the most beneficial elements of their preservice experience in preparing them for work in $21^{\text {st }}$ century schools. Program graduates' openness to collaboration was a significant finding given collaboration's role in effective school reform (Elmore, 1995; Fullan \& Hargreaves, 1992; Little, 1982; Louis \& Marks, 1998).

Important elements of collaboration were lacking from a substantial number of teachers" reports on the scale. For instance, the majority of teachers did not report inviting colleagues into their classrooms to observe and discuss their practice. Being willing to expose one's teaching to peers in order to grow professionally has been shown to be an effective tool for successful educational reform (Lewis, Perry \& Hurd, 2004; Little, 1982). As one of the interviewees lamented in the findings, this resistance to professional sharing could limit professional growth. Teacher isolation can prevent necessary change from taking place (Clandinin \& Connelly, 1995; Lortie, 1975). Whether the lack of use of peer observation and feedback was a result of a lack 
of emphasis on this important form of collaboration during their preservice program, or more a consequence of a lack of access to release time, is not clear from the study's findings.

Although all six interviews spoke extensively about their involvement with the families and communities with whom they teach, most of the teachers in the larger pool who completed the TAMS, reported low levels of collaboration with families and communities. Yet, family and community involvement are both important elements of successful school change (Cooper, 2003; Ladson-Billings, 1994; Quartz \& TEP Research Group, 2003; Tyack \& Cuban, 1995). Additionally, the teacher population remains primarily white and middle class despite the tremendous increase in diversity within public schools, making the need for teachers to embrace families and communities more crucial (Nieto, 2003). Teacher educators need to increase student teachers' involvement with families and with the communities where they teach.

\section{Discussion of Sub-Question 3.}

What is the effect of the teacher education program on graduates' ability to be lifelong learners?

Program graduates report some behaviors indicative of lifelong learners. Evidence of active continual learning was particularly strong in the sharing of the six graduates interviewed. The research design did not allow for a direct correlation between the teacher education program and graduates' ability to be lifelong learners. However, six graduates did mention specifically the development of lifelong learning as something that sustained their passion for teaching. Another graduate mentioned 
the program's emphasis on risk taking helped sustain him. One preservice teacher wrote that instructors' emphasis on joining a professional organization would help sustain her passion for teaching. As discussed earlier, reflection and collaboration, both important components of lifelong learning were referenced by a large number of graduates as important contributors to their ability to sustain their passion for teaching.

The idea of lifelong learning for teachers encompasses a wide range of characteristics. Teachers who are lifelong learners take risks, collaborate with their peers, students, parents, and the community (Caine \& Caine, 1997; Danielewicz, 2001; Hansen, 1999; Little, 1982; Louis \& Marks, 1998). They bring personal relevance to their work, and continue to explore their content area. They reflect deeply on their practice (Goodlad, 1994; Weiss \& Weiss, 2001; Zeichner \& Liston, 1987).

The six teachers interviewed were all strong active learners with impressive lists of participation in professional learning opportunities and involvement in collaborative processes. Interviewees spoke of their keen personal interest in their subject matter and willingness to take risks and experiment with their practice. The larger pool of program graduates who completed the scale tool also reported some behaviors indicative of lifelong learners. More than $90 \%$ of the teachers reported usually or always reflecting on their work. Ninety-three percent of the preservice teachers reported that they intended to participate in professional conferences annually. As mentioned in an earlier discussion, some areas of collaborative learning 
indicated a need for some further development such as collaboration with peers, families, and communities.

\section{Discussion of Sub-Question 4.}

How do teacher perceptions differ based on teaching experience?

Related to the question of the impact of school culture on teachers' perceptions was the assumption that the amount of teaching experience could change graduates' perceptions of themselves as change agents. The results from the scale revealed very little correlation between teaching experience and responses. The only statistically significant variation in responses based on teaching experience was in the area of assessment. The longer someone had taught, the more comfortable they were with aligning assessment with standards. This is a sophisticated skill, one that takes experience to perform effectively.

The responses to the survey questions did indicate more of a variation than the scale. More experienced teachers from Groups I-III had significantly more opinions about methods courses (both positive and negative) than the Group IV, preservice teachers. The veteran teachers also mentioned professors who helped sustain their passion for teaching twice as often as novice teachers. Group IV, preservice teachers mentioned the classroom management course as beneficial more frequently than experienced teachers, probably because management is a developmental skill. It is possible that veteran teachers either master the art of classroom management or leave the profession. 
Discussion of Sub-Question 5.

What elements of the teacher education program do graduates feel prepared them for working in schools undergoing major school reform?

Responses to both the survey questions as well as the more in-depth interviews and portfolios analysis revealed most graduates felt adequately prepared for their jobs in $21^{\text {st }}$ century schools. In response to the survey question about which elements of the program were most beneficial, more than half of responses identified their field experience where they get hands-on experience with students. Recent research showed that adults like children learn best through active engagement in experiences and reflection on those experiences (Bransford et al., 2000; Korthagen \& Kessels, 1999). The graduates' responses affirmed that research attesting to the value of the program's extensive all year field experience and the opportunity to reflect on that experience in the safe environment of the cohort.

Collaboration was another beneficial element of the preservice program. Previous research also showed that professional collaboration is an essential element of successful school change (Elmore, 1995; Fullan \& Hargreaves, 1992; Little, 1982; Louis \& Marks, 1998). This is discussed more under of the research question that directly addresses collaboration.

A third noted benefit to the program was the influence of inspiring leaders. The importance of modeling was not revealed in the literature on successful school change, however it does confirm Vygotsky's theory of social constructivism and the importance of apprenticeships and scaffolding in the learning process (Wink \& 
Putney, 2002). Across all measurement tools, teachers reported caring deeply about their students. They believed that their students were capable and worthy of a teacher's advocacy. Noddings addresses modeling "caring" as an essential element of both teaching and teacher education (Goldstein \& Freedman, 2003; Noddings, 1986). The graduates affirmed Noddings' work as they shared, in both the responses to the survey questions and in the interviews, their appreciation for professors and mentor teachers who modeled caring and putting students first.

Current educational reforms revolve around attempts to address the achievement gap between whites and children of color and poverty (Haycock, 1998). All six interviewees talked passionately about grappling with the complex issues of social justice, second language acquisition, and diversity, but survey results indicated that only $11 \%$ of graduates noted preparation in issues of diversity and social justice. In addition, $10 \%$ of the graduates shared that inadequate training in multicultural education and teaching English Language Learners hindered them in their current jobs. Cultural responsive teaching should receive further exploration by teacher education program designers in preparing teachers to be change agents within increasingly diverse $21^{\text {st }}$ century schools.

Discussion of Sub-Question 6.

What elements of the teacher education program do graduates feel hindered their preparation for working in schools undergoing major reform?

Program graduates discussed a number of areas that they believed hindered their preparation for working in schools undergoing major reform. The most 
commonly cited concerns involved pedagogical content knowledge. Most of their complaints can be classified as components of teacher competence. Graduates asked for more specific pedagogical content knowledge in areas of literacy and mathematics and for instructors to model best practices. They also asked for more hands-on opportunities to apply theories to practice. These requests aligned with Korthagen and Kessels' (1999) research findings on the development of more effective ways to merge learning theory and practice during student teaching. Program graduates struggle with connecting theory and practice were also similar to the findings from Mintrop's (2001) and More's (2003) studies that examined their teacher preparation programs' attempts to teach constructivist-teaching methods. Both Mintrop and More reported their preservice teachers had difficulty making connections between constructivist course work and application of those strategies out in the field. Graduates responses supported research that found teacher education programs needed to do a better job preparing preservice teachers for the disconnect between best practices presented theoretically in course work and the actual practices used in many K-12 schools (Hoy \& Rees, 1997).

Although the vast majority of participants reported frequent use of reflection in their practice, a small percentage of graduates mentioned reflection as a hindrance to their preparation. This finding should be of concern because researchers have documented the importance of reflection in the professional growth of teachers (Danielewicz, 2001; Dewey, 1904; Weiss \& Weiss, 2001; Zeichner \& Liston, 1987). While $5 \%$ of graduates mentioned reflection as a hindrance, another $7 \%$ found it as 
one of elements of the program that helped them to sustain their passion for teaching. The lack of frequent positive responses to reflection within the program may be indicative of the way in which preservice teachers were asked to reflect and/or the timing of that reflection. As mentioned in the findings, one of the interviewees complained that she felt she was asked to reflect before she had enough experience to reflect upon. In contrast, Dewey (1904) argued that preservice teachers have ample years as students to use as a rich source of reflection on the teaching/learning process. Given the importance of reflection in the learning process of teachers, it may be worth exploring ways to enhance the development of reflection in preservice teachers.

\section{Discussion of Sub-Question 7.}

How do the perceptions of teachers-as-change agents differ based on whether they are working in a school that has established a professional community with shared norms of collaboration?

The question of the influence on school norms on teachers ability to be teacher-change-agents was originally motivated by research that strongly correlated the school norms of professional collaboration with successful school reform (Elmore, 1995; Little, 1982; Louis \& Marks, 1998). It was also motivated by research that documented the difficulty of implementing school reforms when teachers were isolated and not integrally involved in the change process (Clandinin \& Connelly, 1995; Sikes, 1992; Spencer 1996). In addition, researchers reported how difficult it was for teachers to sustain their passion when they worked in schools that were not 
supportive of the types of innovations presented during their teacher preparation (Hargreaves \& Jacka, 1995).

This study was not designed in a way that could filter out the influence of school norms on graduates' behaviors and attitudes. A large comparative study would need to be designed where graduates identified whether their current school norms honored the various attributes of teacher change agents. This would require clear operational definitions of both the school norms of professional collaboration and of the attributes of teacher change agents in order to have a common language for both the participants and researchers to work.

\section{Implications}

The findings from this study provide some valuable information to teacher education program designers. Exploring areas that graduates identified as strengths or weaknesses and looking at self-reported behaviors will enable program faculty to look for areas for potential development. The study revealed areas of strength revolving around the teachers' deep sense of caring for their students, their willingness to seek consultation over concerns about the emotional and academic well being of their students, and their reported frequent reflection on their practice. Areas of weakness revolved around the graduates lack of reported involvement in certain types of collaboration with colleagues, parents and their school's community, as well as a lack of openness to establishing democratically run classrooms. Graduates reported that the most beneficial elements of their teacher preparation included extensive field experience, learning best practices, the cohort model, and learning effective classroom 
management techniques. Graduates stated that the least helpful aspects of their teacher preparation were irrelevant methods classes and a lack of connection between theory and practice. Based on these findings a number of recommendations can be made for enhancing the program's efforts to nurture the development of teacher change agents.

\section{Involvement with Families and Communities}

Graduates seemed to maintain a sense of agency for their students, yet many appeared reluctant to include parents, the community, or their students in decision making and planning. For instance, few of the teachers in the study identified as beneficial their coursework in diversity and social justice issues. This lack of recognition of the importance of diversity issues should be of concern to program faculty. Understanding diversity issues helps teachers develop a sense of agency for their students (Cooper, 2003; Nieto, 2003; Oakes \& Lipton, 2003). This lack of reference to diversity issues may also be related to the teachers self-report of low levels of interaction with students' families and communities. To encourage preservice teachers to embrace comfortably families and communities in the learning process, teacher educators should expand requirements for community outreach and parental involvement (Quartz \& TEP Group, 2003). Similarly, social justice and diversity issues need to be infused across the course work.

\section{Democratic Classrooms}

Another area of weakness in program graduates involves their lack of willingness to establish democratic classrooms. Democratic classrooms are an integral 
component of progressive education reform, in which students learn to be part of democratic citizenry. Establishing democratic classrooms, where teachers are willing to give up some of their control and share power with students requires risk-taking. Teacher educators should model democratically run classes at the university level and include opportunities for preservice teachers to reflect on the process if they want their graduates to consider empowering their own future students.

Theory and Practice

Graduates express concern over a disconnect between theory and practice. Specific methods instruction must be aligned closely with field experience in order to address this problem. Preservice teachers must be guided to make explicit connections between theory and practice. For instance, preservice teachers should learn how to design lessons that connect their students' culture to the curriculum. Faculty need to coordinate more with colleagues in $\mathrm{K}-12$ schools so that best practices presented in courses are also modeled out in the field. Induction programs that provide mentoring and collaborative support groups could to be considered to help new graduates integrate the theory into their practice in the first few years of teaching.

\section{Peer Collaboration}

Graduates report infrequent occasions when colleagues were invited in to observe their practice and discuss their teaching. Research on the benefits of the Japanese lesson study model indicates that learning from colleagues can be a valuable and effective tool for professional growth (Lewis et al., 2004). Preservice teachers should be given opportunities to expose their teaching to their peers, both in their 
course work through micro-teaching and out in their field placements. Practice with structured constructive peer review during teacher preparation could help teachers be less resistant and intimidated by the process later in their careers. Relationship Building

Teacher educators teach their preservice teachers about the importance of building relationships. Nieto (2003) reports that love and deep caring are major reason for teachers' resilience while teaching under difficult conditions. Teachers' sense of agency grows through their bond with students. As Nieto expresses eloquently, "Teaching is about love because it involves trust and respect and because at its best, it depends on close and special relationships between students and teachers (p. 391). Program graduates appear to abide by the principle of getting to know students well, even if they were less likely to engage parents and the students' wider communities, according to their reports on the scale. Relationship building is a crucial first step to successfully connecting the curriculum to one's students, and making it more relevant and accessible. When asked what from the program helps to sustain their passion for teaching, $13 \%$ of the teachers argued that nothing in a program could help sustain passion, rather their relationships with students kept them coming back to the classroom day after day. Caring for students should be honored and nurtured during teacher preparation.

The findings indicate that preservice teachers appreciated the time their instructors took to build relationships with them and to connect the curriculum to experiences out in the field. Numerous graduates named specific instructors who had 
influenced their teaching over the long term. For example, a 1991 graduate wrote about one professor, "He keeps me going on a daily basis with his words of wisdom, his humor, and his skill in teaching. I love his class! His words are still in my ears years later!" After 12 years, this teacher still expressed a strong connection with a former instructor. Teacher educators need to make sure to model what they advocate.

The cohort model, in which a leader stays with one group throughout their tenure in the program, provides an important opportunity for building relationships. Cohort retreats, one-on-one check-ins, sharing food and social discourse, and asking deep probing questions, are just some of the ways graduates mentioned instructors had helped build strong relationships. Cohort leaders cared for their students' needs by establishing a safe nurturing learning community within their cohorts, a learning community referenced frequently in the responses by program graduates. However, these actions take time and energy beyond the class time together. Cohort leaders need to be given the time and support to get to know their own students well.

Related to the issue of a teacher educator's personal influence on preservice teachers' developing sense of agency, is the role of the mentor teacher. Teacher education programs need to have access to a pool of mentor teachers who will take the time to connect to their student teachers. Mentor teachers also need to model relationship-based relevant teaching, teaching that will inspire future teachers to advocate for their own students' well being. 


\section{Summary}

The findings revealed some successful ways the program nurtured the development of graduates' attributes of teachers open to change. Graduates acknowledged the benefits of the cohort model for collaborative reflective practice. They appreciated the modeling of deep caring displayed by many of their instructors. The findings also revealed some areas that teacher educators should consider for further development. Specifically, teacher educators need to build more connections between course work and the field experiences and more opportunities for preservice teachers to be involved with families and communities of their students, which would enable them to successfully make connections with their students' diverse cultural perspectives. Finally, teacher educators should consider providing opportunities for preservice teachers to experience more democratic classrooms where students are empowered to have more ownership in the learning process.

\section{Future Research Directions}

The findings from this study open the door to a number of possible areas for further research:

1. A study involving numerous classroom observations of teachers would reveal any discrepancies between teachers' self-reporting and observable behaviors.

2. An examination of a wider pool of portfolios would allow for more generalization of the rich findings revealed in the examination of the six professional portfolios within this study. 
3. A larger comparative study is advisable to determine if the same findings could be identified in teachers graduating from other teacher education programs. A comparative study could allow the findings to be more generalizable, as well as help determine if a causal relationship exists between the program and its graduates ${ }^{\prime}$ commitment to change.

4. A longitudinal study in which graduates were tracked over the course of multiple years could more accurately reveal potential changes in both perceptions and behaviors of graduates as they acquire more field experience. A longitudinal study could also examine the impact of differences in school norms on graduates' potential for changing perspectives as discussed in question six. In addition, any preconceived notions held by candidates as they entered the program could be factored into a longitudinal study that started at the admissions stage.

\section{Conclusion}

The skills young people need to survive and thrive in this global society are not the same as they were when many of the current school structures were designed. Students enrolled in our schools are also different from students of past generations. Diversity of language, culture, interests, and skills represented by American students call for schools to change in both structure and form (Wagner, 2002). The literature review reveals that school change succeeded only when teachers actively informed the process (Elmore, 1995; Hinds, 2002; Marks \& Louis, 1997; Spencer, 1996). 
This research study takes a first look at whether graduates of a particular teacher preparation program had the characteristics of teachers open to be part of the change process. The six interviewees are exemplary models of teachers ready to continue to change and grow to meet their students' needs. The 282 participants in the larger study also self-reported moderate levels of behaviors indicative of teachers open to change.

One of the graduates, Ann, shares in her portfolio, "It is my quest to continue doing hard things just as I require my students to do hard things. Growth comes from the challenge of doing hard things." Being open to change one's practice requires hard work; work that involves developing competence, a commitment to lifelong learning, and a strong sense of agency with the belief that one's work is important and worthy. This dedicated teacher's words should inspire teacher educators to also be open to the hard work of changing their own practice to meet the constantly evolving needs of their students - future teachers preparing to teach in $21^{\text {st }}$ century schools. 


\section{REFERENCES}

Ayers, W. (2000). A simple justice: Thinking about teaching and learning. In W. Ayers, M. Klonsky, \& G. H. Lyon (Eds.), A simple justice: The challenge of small schools. (pp. 1-8). New York: Teachers College Press.

Bransford, J., Brown, A. \& Cocking, R. (Eds.) (2000). How people learn: Brain, mind, experience, and school. Washington, DC: National Research Council: Committee on Developments in Science of Learning. National Academy Press.

Caine, G., \& Caine, R. (1997). Education on the edge of possibility. Alexandria, VA: Association of Supervision and Curriculum Development.

Center for a New American Dream. (2000, February 22). Kids and commercialism. Retrieved April 10, 2004, from http://www.newdream.org/campaign/kids/facts.html.

Clandinin, D. J. \& Connelly, F. M. (1995). Teachers' professional knowledge landscapes: Advances in contemporary educational thought.(Vol. 15). New York: Teachers College Press.

Cochran-Smith, M. (2001). Constructing outcomes in teacher education: Policy, practice, and pitfalls [Electronic version], Educational Policy Analysis Archives, 9(11), 1-35.

Cochran-Smith, M. (2003, May/June). Assessing assessment in teacher education. Joumal of Teacher Education, 54(3), 187-191.

Cooper, P. (2003). Effective teachers of Black children: Teaching within a community. Journal of Teacher Education, 54(5), 413-428.

Cotton, K. (2001, December). New small leaming communities: Findings from recent literature. Northwest Regional Laboratory. Retrieved December 6, 2001, from http://www.nwrel.org

Cremin, L. (1961). The transformation of the school. New York: Knopf. 
Creswell, J. (2002). Educational research: Planning, conducting, and evaluative quantitative and qualitative research. Upper Saddle River, NJ: Pearson Education, Inc.

Danielewicz, J. (2001). Teaching selves: Identity, pedagogy, and teacher education. Albany, NY: State University of New York Press.

Darling-Hammond, L. (1997a). Doing what matters most: Investing in quality teaching. Kutztown, PA: National Commission on Teaching and America's Future.

Darling-Hammond, L. (1997b). The right to learn: A blueprint for creating schools that work. San Francisco: Jossey-Bass Publishers.

Darling-Hammond, L. (1999). Teacher quality and student achievement: A review of state policy evidence [Electronic version]. Seattle, WA: University of Washington, Center for the Study of Teaching and Policy

Darling-Hammond, L. (2001). Does teacher certification matter? Evaluating the evidence. Educational Evaluation and Policy Analysis, 23(1), 57-77.

Darling-Hammond, L. (2002). Research and rhetoric on teacher certification: A response to "Teacher certification reconsidered" Educational Policy Analysis Archives, 10(26), 1-56.

Davis, S. (2000). Reflective practice of early childhood student teachers through children's work. Ann Arbor, MI: Bell \& Howell Information and Learning Company.

D'Costa, A. G. (1995). Legal aspects of assessing teacher performance. In S. Wegner Soled. (Ed.), Assessment, testing, and evaluation in teacher education_(pp.253300). New York: Ablex Publishing.

Delpit, L. (1995). Other people's children: Cultural conflict in the classroom. New York: The New Press.

Dewey, J. (1904). The relation of theory to practice in the education of teachers. Third Yearbook. Part 1 (Vol. 3, pp. 140-171). Bloomington, Il: Public School Publishing Company.

Dewey, J. (1990). The School and society and the child and curriculum: A centennial edition with a "lost essay." Chicago: University of Chicago Press. 
Dinkelman, T. (2003). Self-study in teacher education: A means and ends tool for promoting reflective teaching. Journal of Teacher Education, 54(1), 6-18.

Elmore, R. F. (1995). Structural reform and educational practice. Educational Researcher, 24(9), 23-26.

Feistritzer, C. E. (2002). Alternative teacher certification: An overview. National Center for Education Information. Retrieved on July 8, 2002, from htp:/www.ncei.com/02_Introduction.html

Ferguson, R. (1991). Racial patterns in how school and teacher quality affect achievement and earnings. Challenge: A Journal of Research on Black Men, $2(1), 1-29$.

Fessler, R. (1995). Dynamics of teacher career stages. In T. R. Guskey, \& M. Hauberman (Eds.), Professional development in education: New paradigms and practices (pp. 171-192). New York: Teachers College Press.

Fullan, M., Galluzzo, G., Morris, P., \& Watson, N. (1998). The rise and stall of teacher education reform. Washington, DC: American Association of Colleges for Teacher Education.

Fullan, M., \& Hargreaves, A. (Ed.). (1992). Teacher development and educational change. Washington, DC: The Falmer Press.

Galluzzo, G., \& Craig, J. R. (1990). Evaluation of preservice teacher education programs. In W. R. Houston (Ed.), Handbook of research on teacher education.(pp. 599-615). New York: Macmillan Publishing Company.

Glass, G.V. (2002). Teacher characteristics. In A. Molnar, (Ed.) School reform proposals: The research evidence. Retrieved on February 18, 2003 from http:/Www.asu.edu/educ/eps1/EPRU/documents/EPRU2002-101-epru-2002101.htm.

Goldberg, M. (2004). The test mess. Phi Delta Kappan, 85(5), 361-366.

Goldhaber, D., \& Brewer, D. (1999). Teacher licensing and student achievement. In C. Finn (Ed.), Better teachers, better schools (pp. 83-101). Washington, DC: Thomas B. Fordham Foundation.

Goldstein, L. \& Freedman, D. (2003). Challenges enacting caring teacher education. Journal of Teacher Education, 54(5), $441-454$. 
Goodlad, J. (1994). Educational renewal: Better teachers, better schools. San Francisco: Jossey-Bass Publishers.

Graves, B .(2003, November 7). Governor issues "call to action" for Oregon children. The Oregonian, p. Al.

Greene, J. P. (2001). High school graduation rates in the United States. Retrieved December 1, 2001, from The Manhattan Institute for Policy Research, Center for Civic Innovation: Black Alliance for Educational Options. http://ww.manhanttan-institute.org

Hammerness, K. (2003). Learning to hope, or hoping to learn? The role of vision in the early professional lives of teachers. Journal of Teacher Education, 54(1), 43-56.

Hansen, D. (1994). Teaching and the sense of vocation. Educational Theory, 44(1), $259-275$.

Hansen, D. (1999). Understanding students. Journal of Curriculum and Supervision, $14(2), 171-185$.

Hargreaves, A., \& Jacka, N. (1995). Induction or seduction? Postmodern patterns of preparing to teach. Peabody Journal of Education, 70, 41-63.

Hatch, T. (2000). What does it take to break the mold? Rhetoric and reality in new American schools. Teachers College Record, 102(3), $561-589$.

Havelock, R. (1995). The change agent's guide to innovation in education $2^{\text {nd }}$ ed. Englewood Cliffs, NJ: Educational Technology Publications.

Haycock, K. (1998). Good teaching matters...a lot. Thinking K-16: A Publication of the Education Trust, 3(2), 3-14.

Hillard. A., III. (1991). Do we have the will to educate all children? Educational Leadership, 49(1), 31-36.

Hinds, M. (2002). Camegie challenge 2002: Teaching as a clinical profession: A new challenge for education. New York: Carnegie Corporation of New York. Retrieved on October 15, 2002 from http;/www.camegie.org

The Holmes Group. (1986). A report of the Holmes Group: Tomorrow's teachers. East Lansing, MI: The Holmes Group Inc. 
hooks, b. (1994). Teaching to transgress: Education as the practice of freedom. New York: Routledge.

Hoy, W., \& Rees, R. (1977). The bureaucratic socialization of student teachers. Joumal of Teacher Education, 28(1), 23-26.

Jorgenson, O., \& Vanosdall, R., (2002). The death of science? What we risk in our rush toward standardized testing and the three R's. Phi Delia Kappan, 83(8), $601-605$.

Kluth, P. \& Straut, D. (2003, May/June). Do as we say and as we do: Teaching and modeling collaborative practice in the university classroom. Journal of Teacher Education, 54(3), 228-240.

Kornfeld, J., Marker, P., Ruddell, M. R., Cooke, T., \& Fernlund, P. (2003, Summer). Through the looking-glass: Self-study in an era of accountability. Teacher Education Quarterly, 30(3), 7-22.

Korthagen, F. A., \& Kessels, J. P. (1999). Linking theory and practice: Changing the pedagogy of teacher education. Educational Researcher, 28(4), 4-17.

Kozol, J. (1991). Savage inequalities: Children in America's schools. New York: Crown Publications.

Kvale, S. (1996). InterViews: An introduction to qualitative research interviewing. Thousand Oaks, CA: Sage Publications.

Laczko-Ker, 1., \& Berliner, D. (2002, September). The effectiveness of "Teach for America" and the under-certified teachers on student academic achievement: A case of harmful public policy. Retrieved September 14, 2002, from http:/epaa.asu.edu/epaa/vion37/

Ladson-Billings, G. (1994). The dreamkeepers: Successful teachers of African American children. San Francisco: Jossey-Bass.

Levine, L. W. (1996). The opening of the American mind: Canons, culture, and history. Boston: Beacon Press.

Lewis, C., Perry, R., \& Hurd, J. (2004). A deeper look at lesson study. Educational Leadership, 61(5), 18-22.

Liston, D., \& Zeichner, K. (1991). Teacher education and the social conditions of schooling. New York: Routledge. 
Little, J. W. (1982). Norms of collegiality and experimentation: Work place conditions of school success. American Educational Research Journal, 19(3), $325-340$.

Lortie, D.C. (1975) Schoolteacher: A sociological siudy. Chicago: University of Chicago Press.

Louis, K. S., \& Marks, H. (1998). Does professional community affect the classroom? Teachers' work and student experiences in restructuring schools. American Journal of Education, 106(8), 532-575.

Marks, H. M., \& Louis, K. S. (1997). Does teacher empowerment affect the classroom? The implications of teacher empowerment for instructional practice and student academic performance. Educational Evaluation and Policy Analysis, 19(3), 245-275.

Marshall, C., \& Rossman, G. (1999). Designing qualitative research (3rd ed.). Thousand Oaks, CA: Sage Publications, Inc.

Mathis, W. (2003). No child left behind: Costs and benefits. Phil Delta Kappan, 84(9), 665-668.

Merrow, J. (2001). Undermining standards. Phil Delta Kappan, 82(9), 652-660.

Mintrop, H. (2001). Educating students to teach in a constructivist way: Can it all be done? [Electronic version]. Teachers College Record, 103(2), 207-239.

More, R. (2003). Reexamining the field experiences of preservice teachers. Joumal of Teacher Education, $54(1), 31-42$.

Narode, R., Peterson, K., Petrie, J., Rennie-Hill, L., \& Sherman, D. (1991). Preparing the secondary urban educator. unpublished manuscript, Portland State University, Oregon.

Nathan, L. (2002). The human face of the high-stakes testing story. Phi Delta Kappan, $83(8), 595-600$.

National Center for Education Statistics. (1999). Teacher Quality: A report on the preparation and qualifications of public school teachers. Washington DC: U.S. Department of Education.

National Commission on Teaching and America's Future. (1996). What matters most: Teaching for America's future. New York: Columbia University, Teachers College. 
Nemser, S. F. (1983). Learning to teach. In L. Shulman, (Ed.), Handbook of teaching and policy. (pp.150-170). New York: Longman.

Nemser, S.F., \& Buchmann, M. (1985, Fall). Pitfalls of experience in teacher preparation. Teachers College Record, 87(1), 53-65.

Nicto, S. (2002). Language, culture, and teaching: Critical perspectives for a new century. Mahwah, NJ: Lawrence Erlbaum Associates.

Nieto, S. (2003). Challenging the current notions of 'highly qualified teachers.' Journal of Teacher Education, 54(5), 386-399.

Noddings, N. (1986). Fidelity in teaching, teacher education, and research for teaching. Harvard Education Review, 56(4). 496-510.

Oakes, J., \& Lipton, M. (2003). Teaching to change the world $\left(2^{\text {nd }}\right.$ ed.). New York: McGraw Hill Higher Education.

O'Hair, M., \& Odell, S. J. (Ed.). (1995). Educating teachers for leadership and change (Vol. 3). Thousand Oaks, CA: Sage Publications Company.

O'Hair, M., \& Reitzug, U. (1997). Teacher leadership: In what ways? For what purpose? Action in Teacher Education, 19(3), 65-76.

Olsen, B., \& Kirtman, L. (2002, March). Teacher as mediator of school reform: An examination of teacher practice in 36 California restructuring schools. [Electronic version]. Teachers College Record, 104(2), 301-324.

Oregon Food Bank. (n.d.) The state of hunger: Annual statistics for the Oregon Food Bank Network. Retrieved on May 9.2003 Irom

htrp:/www.oregonfoodbank.org/research_and_action/network_statistics.html

Paige, R. (2002). An overview of America's education agenda. Phi Delta Kappan, $83(9), 708-713$.

Pallant, J. (2001). SPSS survival manual: A step by step guide to data analysis using SPSS for Windows (Version 10 and 11). Philadelphia: Open University Press.

Proefriedt, W. (1994). How teachers learn: Towards a more liberal teacher education. New York: Teachers College Press. 
Quartz, K. H., \& TEP Research Group. (2003). "Too angry to leave": Supporting new teachers' commitment to transform urban schools. Joumal of Teacher Education, 54(2), 99-111.

Raymond, M., \& Fletcher, S. (2002, Spring). The Teach for America evaluation, Hoover Institute. Retrieved July 3, 2002, from htp:// www.educationnet.org

Rosiek, J. (2003). Emotional scaffolding: An exploration of the teacher knowledge at the intersection of student emotion and the subject matter. Jownal of Teacher Education, 54(5), 399-412.

Sanders, W. L., \& Horn, S. P. (1994). The Tennessee value-added assessment system (TVAAS): Mixed model methodology in educational assessment. Joumal of Personnel Evaluation in Education, 8, 299-311.

Sarason, S. (2000). Contexts of productive learning, governance, charter schools, pilot schools, the creation of settings, and the Wailing Wall. In E. Clinchy (Ed.), Creating new schools: How small schools are changing American education (pp.191-202). New York: Teachers College Press.

Sarason, S., Davidson, K., \& Blatt, B. (1986). The preparation of teachers: An unstudied problem in education (Rev. ed.). Cambridge, MA: Brookline Books.

Schein, E. H. (1985). Organizational culture and leadership. San Francisco: JosseyBass Publishers.

Shulman, L.S. (1987). Knowledge and teaching: Foundations of the new reform. Harvard Educational Review, 57(1), 1-22.

Sikes, P. (1992). Imposed change and the experienced teacher. In M. Fullan \& A. Hargreaves (Eds.), Teacher development and educational change (pp. 36-55). Washington, DC: The Falmer Press.

Spencer, D. (1996). Teachers and educational reform. Educational Researcher, 25(9), $15-17$.

Stoll, L. (1992). Teacher growth in the effective school. In M. Fullan \& A. Hargreaves (Eds.), Teacher development and educational change (pp. 104-122). Washington, DC: The Falmer Press.

Tatum, B. D. (2003). "Why are all the black kids sitting together in the cafeteria?" and other conversations about race. New York: Basic Books. 
Thudeau, G. (2003, February 24). Doonesbury. The Oregonian. p. E10.

Tyack, D., \& Cuban, L. (1995). Tinkering toward utopia: A century of public school reform. Boston: Harvard Education Press.

U.S. Bureau of Labor Statistics. (2003). Metropolitan area employment and unemployment summary. Retrieved January 8, 2004, from http://www.bls.gov/news.release/metro.nro.htm

U. S. National Commission on Excellence in Education. (1983). A nation at risk: The imperative for educational reform: A report to the nation and the secretary of education. Washington, DC: U. S. Department of Education.

U.S. Office of Postsecondary Education, Office of Policy Planning and Innovation (2002). Meeting the highly qualified teachers challenge:The secretary's annual report on teacher quality. Washington, DC: U.S. Department of Education.

Vaughn, S., Schumm, J. S., \& Singagub, J. (1996). Focus Group Interviews in education and psychology. Thousand Oaks, CA: Sage Publications.

Wagner, T. (2002). Making the grade: Reinventing America's schools. New York: Routledge.

Walsh, K. (2001). Teacher certification reconsidered: Stumbling for quality. Baltimore, Maryland: The Abell Foundation.

Wayne, A. J., \& Youngs, P. (2003, Spring). Teacher characteristics and student achievement gains: A review. Review of Educational Research, 73(1),89-122.

Weiss, E. M., \& Weiss, S. (2001). Doing reflective supervision with student teachers in a professional development school culture. Reflective Practice, $2(2), 125-$ 154.

Wilson, S., Floden, R., \& Ferrini-Mundy, J. (2001). Teacher preparation research: Cument knowledge, gaps and recommendations: A research report prepared for the U.S. Department of Education [Electronic Version] Seattle, WA: Center for the Study of Teaching and Policy.

Windschitl, M. (2002). Framing constructivism in practice as the negotiation of dilemmas: An analysis of the conceptual, pedagogical, cultural, and political challenges facing teachers. Review of Educational Research, 72(2), 131-175.

Wink, J., \& Putney, L. (2002). A vision of Vygotsky. Boston: Allyn \& Bacon. 
Wynne, I. (2001). Teachers as leaders in educational reform. (ERIC Digest No.

ED462376)

Yatvin, J, (2002). Babes in the woods: The wanderings of the national reading panel. Phi Delta Kappan, 83(5), 364-352.

Zeichner, K. (1999). The new scholarship in teacher education. Educational Researcher, 28(9), 4-13.

Zeichner, K., \& Liston, D. (1987). Teaching students to reflect. Harvard Educational Review, 57(1), 23-48. 
APPENDIX A

TAMS: TEACHER ADAPTABILITY MEASUREMENT SCALE 


\begin{tabular}{|l|l|}
\hline \multicolumn{2}{|l|}{ Teacher Adaptability Measurement Scale: TAMS SCALE } \\
\hline Directions: Please circle the word that best describes you. \\
\hline I have a degree in the subject I teach. & Yes No \\
\hline $\begin{array}{l}\text { I have a passing score on a content } \\
\text { knowledge test (Praxis II) in the subject I } \\
\text { am currently teaching. }\end{array}$ & Yes No NA \\
\hline $\begin{array}{l}\text { I align learning theory to my practice on a } \\
\text { routine basis. }\end{array}$ & Never Sometimes Usually Always \\
\hline $\begin{array}{l}\text { The assessments I design match my unit } \\
\text { objectives. }\end{array}$ & Never Sometimes Usually Always \\
\hline $\begin{array}{l}\text { I consider myself up-to-date on best } \\
\text { practices. }\end{array}$ & Never Sometimes Usually Always \\
\hline $\begin{array}{l}\text { I have taken courses in learning theory. } \\
\text { Lessons I design actively engage students } \\
\text { with subject matter. }\end{array}$ & Yes \\
\hline $\begin{array}{l}\text { I design lessons that are developmentally } \\
\text { appropriate. }\end{array}$ & Never Sometimes Usually Always \\
\hline $\begin{array}{l}\text { I incorporate creative engaging strategies } \\
\text { to teach standards. }\end{array}$ & Never Sometimes Usually Always \\
\hline $\begin{array}{l}\text { I differentiate curriculum to meet diverse } \\
\text { needs of students. }\end{array}$ & Never Sometimes Usually Always \\
\hline $\begin{array}{l}\text { I read professional literature in my field. } \\
\text { I attend professional conference or } \\
\text { workshops annually. }\end{array}$ & Never Sometimes Usually Always \\
\hline $\begin{array}{l}\text { I routinely discuss with colleagues best } \\
\text { practices. }\end{array}$ & Never Sometimes Usually Always \\
\hline $\begin{array}{l}\text { I invite colleagues to observe and discuss } \\
\text { my practice. }\end{array}$ & Never Sometimes Usually Always \\
\hline
\end{tabular}




\begin{tabular}{|l|l|}
\hline $\begin{array}{l}\text { I invite colleagues to observe and discuss } \\
\text { my practice. }\end{array}$ & Never Sometimes Usually Always \\
\hline $\begin{array}{l}\text { I communicate with parents about students' } \\
\text { learning needs. }\end{array}$ & Never Sometimes Usually Always \\
\hline $\begin{array}{l}\text { I invite parents and community members } \\
\text { into my room. }\end{array}$ & Never Sometimes Usually Always \\
\hline $\begin{array}{l}\text { I reflect on the effectiveness of my lessons } \\
\text { and unit plans. }\end{array}$ & Never Sometimes Usually Always \\
\hline I solicit input from students. & Never Sometimes Usually Always \\
\hline $\begin{array}{l}\text { I utilize community resources to enhance } \\
\text { my teaching. }\end{array}$ & Never Sometimes Usually Always \\
\hline I experiment with new strategies. & Never Sometimes Usually Always \\
\hline $\begin{array}{l}\text { I get to know my students as individual } \\
\text { human beings. }\end{array}$ & Never Sometimes Usually Always \\
\hline \begin{tabular}{l} 
I get to know my students' family. \\
\hline $\begin{array}{l}\text { I make the curriculum relevant to students' } \\
\text { lives. }\end{array}$
\end{tabular} & Never Sometimes Usually Always \\
\hline $\begin{array}{l}\text { I incorporate my students' cultures into the } \\
\text { classroom. }\end{array}$ & Never Sometimes Usually Always \\
\hline $\begin{array}{l}\text { I give students voice in the design and } \\
\text { curriculum content. }\end{array}$ & Never Sometimes Usually Always \\
\hline $\begin{array}{l}\text { I celebrate students' strengths as well as } \\
\text { focus on improving their weaker skills. }\end{array}$ & Never Sometimes Usually Always \\
\hline $\begin{array}{l}\text { I believe that all students can succeed. } \\
\text { the emotional well-being of a student. } \\
\text { the academic well-being of a student. }\end{array}$ & Never Sometimes Usually Always \\
\hline I run my classroom democratically. & Never Sometimes Usually Always \\
\hline
\end{tabular}


Directions: Using the space below please respond to the following questions.

1. What types of experiences during the Graduate Teacher Education Program were most beneficial in preparing you for the realities of teaching in a $21^{\text {st }}$ century public school?

2. What types of experiences during the Graduate Teacher Education Program were least helpful in preparing you for the realities of teaching in a $21^{\text {st }}$ century public school?

3. What types of experiences during the Graduate Teacher Education Program do you feel have helped sustain your passion for teaching when faced with the day to day work in your school?

4. What would you change in the Graduate Teacher Education Program?

5. What should I have asked about your experience in the Graduate Teacher Education Program? 
APPENDIX B

TAMS 1 


\begin{tabular}{|c|c|}
\hline \multicolumn{2}{|c|}{ Teacher Education Program Survey (for preservice teachers) } \\
\hline \multicolumn{2}{|c|}{$\begin{array}{l}\text { Directions: Please circle the response that best reflects who you in your } \\
\text { development as a professional educator. }\end{array}$} \\
\hline \multicolumn{2}{|c|}{$\begin{array}{l}\text { TEPS Subsection One: } \\
\text { Teacher's professional competence ( } 8 \text { items) }\end{array}$} \\
\hline 1. I have a degree in the subject I teach. & Yes \\
\hline $\begin{array}{l}\text { 2. I have a passing score on a content } \\
\text { knowledge test in the subject I plan to } \\
\text { teach. }\end{array}$ & Yes \\
\hline $\begin{array}{l}\text { 3. I was taught how to align learning } \\
\text { theory to my practice. }\end{array}$ & Yes \\
\hline $\begin{array}{l}\text { 4. I was taught how to make the } \\
\text { assessments I design match my unit } \\
\text { objectives. }\end{array}$ & Yes \\
\hline $\begin{array}{l}\text { 5. Lessons I design actively engage } \\
\text { students with subject matter. }\end{array}$ & Never Sometimes Usually Always \\
\hline $\begin{array}{l}\text { 6. I know how to design lessons that are } \\
\text { developmentally appropriate. }\end{array}$ & Yes \\
\hline $\begin{array}{l}\text { 7. I know how to incorporate creative } \\
\text { engaging strategies to teach standards. }\end{array}$ & Yes \\
\hline $\begin{array}{l}\text { 8. I know how to differentiate curriculum } \\
\text { to meet the diverse needs of students. }\end{array}$ & Yes \\
\hline \multicolumn{2}{|c|}{$\begin{array}{c}\text { TEPS Subsection Two: } \\
\text { Teacher as a learner ( } 7 \text { items) }\end{array}$} \\
\hline $\begin{array}{l}\text { 9. I work collaboratively with the } \\
\text { members of my cohort. }\end{array}$ & Never Sometimes Usually Always \\
\hline $\begin{array}{l}\text { 10. I reflect on the effectiveness of my } \\
\text { lessons and unit plans. }\end{array}$ & Never Sometimes Usually Always \\
\hline $\begin{array}{l}\text { 11. I solicit input from peers, students and } \\
\text { parents. }\end{array}$ & Never Sometimes Usually Always \\
\hline $\begin{array}{l}\text { 12. I know how to utilize community } \\
\text { resources to enhance my teaching }\end{array}$ & Yes \\
\hline
\end{tabular}




\begin{tabular}{|c|c|}
\hline 13. I subscribe to a professional journal & Yes \\
\hline $\begin{array}{l}\text { 14. I have attended professional } \\
\text { conference or workshop. }\end{array}$ & Yes \\
\hline 15. I experiment with new strategies. & Never Sometimes Usually Always \\
\hline $\begin{array}{r}\text { TEPS: } \\
\text { Teacher as advoca }\end{array}$ & $\begin{array}{l}\text { Subsection Three: } \\
\text { for students' lives. (10 items) }\end{array}$ \\
\hline $\begin{array}{l}\text { 16. I gef to know my students as } \\
\text { individual human beings. }\end{array}$ & Never Sometimes Usually Always \\
\hline 17. I get to know my students' family. & Never Sometimes Usually Always \\
\hline $\begin{array}{l}\text { 18. I make the curriculum relevant to } \\
\text { students' lives. }\end{array}$ & Never Sometimes Usually Always \\
\hline $\begin{array}{l}\text { 19. I incorporate my students' cultures } \\
\text { into the classroom. }\end{array}$ & Never Sometimes Usually Always \\
\hline $\begin{array}{l}\text { 20. I give students voice in the design and } \\
\text { curriculum content. }\end{array}$ & Never Sometimes Usually Always \\
\hline $\begin{array}{l}\text { 21. I tap into students' strengths as well as } \\
\text { focus on improving their weaker skills. }\end{array}$ & Never Sometimes Usually Always \\
\hline 22. I believe that all students can succeed. & Never Sometimes Usually Always \\
\hline $\begin{array}{l}\text { 23. I seek consultation when concerned } \\
\text { about the emotional well-being of a } \\
\text { student. }\end{array}$ & Never Sometimes Usually Always \\
\hline $\begin{array}{l}\text { 24. I seek consultation when concerned } \\
\text { about the academic well-being of a } \\
\text { student. }\end{array}$ & Never Sometimes Usually Always \\
\hline $\begin{array}{l}\text { 25. I plan to run my classroom } \\
\text { democratically. }\end{array}$ & Never Sometimes Usually Always \\
\hline
\end{tabular}


APPENDIXC

INDIVIDUAL INTERVIEW QUESTIONS 
Individual Interview Questions to use with the six continuing teacher license candidates whose porffolios will be examined.

1. Looking back on your experience in GTEP, what elements do you believe helped you most in preparing you to teach?

2. Which elements do you think were least helpful, or possibly hindered your development as a teacher?

3. If you were to design a preservice program what would you make sure was a component and why?

4. How well do you feel GTEP prepared you for the realities of working in a changing educational landscape?

5. Did the program give you appropriate useful tools for reflective practice?

6. How effective was the cohort model for you as a preservice teacher?

7. Do you see any carryover from the cohort model to your role on your current staff?

8. What/ if any tools did your preservice program provide you with that have enabled you to hold on to your sense of agency as an educator? 
APPENDIX D

PORTFOLIO DEVELOPMENT GUIDE 
BUILDING A PORTFOLIO

FOR

\section{A CONTINUING TEACHING LICENSE}

SECTION I-INTRODUCING YOURSELF AND YOUR SCHOOL

"Who am I?" Essay

Professional Vita

Description of your School

26. Neighborhood Demographics

27. Physical Plant

28. Overview of School Population

Supporting Artifacts

Descriptions of -

Your Faculty

- Your School's Broad Organizational Patterns

- School-Wide Goals, Initiatives, or Reform Efforts

Supporting Artifacts

\section{SECTION II-CURRICULUM PLANNING}

(Addresses Advanced Competencies 1, 2, 3, 4, 6, 7, 8, 9)

Critical Question

Description of how you use State Standards and Benchmarks in your Planning

Year I

- Focused Unit of Instruction

- Reflection on Focused Unit

Year II

- Focused Unit of Instruction

Reflection on Focused Unit

Problem-Based Reflection

Voices of Others (if appropriate)

Summary Reflection related to your Critical Question

\section{SECTION III - INSTRUCTION}

(Addresses Advanced Competencies 1, 2, 3, 4, 5, 6, 7, 9)

Critical Question

Descriptions of -

- Factors that you consider in organizing your classroom for instruction

* How you involve families in the life of your classroom

Supporting Artifacts

Year 1

* Three Examples of a daily Lesson Plan from your Focused Unit-1 early, 1 mid-way, and 1 late in the unit

* Supporting Artifacts

Video tape of you teaching one of the Lessons 
Year II

Reflection on the video-taped Lesson

- Three Examples of a daily Lesson Plan from your Focused Unit-1 early, 1 mid-way, and 1 late in the unit,

Supporing Artifacts

Video Tape of you teaching one of the lessons

* Reflection on the video-taped lesson

Problem-Based Reflection

Voices of Others (if appropriate)

Summary Reflection related to your Critical Question

\section{SECTION IV - ASSESSMENT}

Critical Question

(Addresses Advanced Competencies 1, 3, 6, 7, 8, 9)

Descriptions of --

- How you approach standardized testing (if appropriate)

" The achievement levels in your "focus" class

- Your classroom assessment practices

- How you involve students and their families in assessing learning

Supporting Artifacts

Yearl

- Case Study of 3 students' academic progress during the Focused Unit

Year II

- Supporting Artifacts

Case Study of 3 student's academic progress during the Focused Unit

- Supporting Artifacts

Voices of Others (if appropriate)

Summary Reflection related to your Critical Question

\section{SECTION V-MANAGEMENT}

Critical Question

(Addresses Advanced Competencies 2, 3, 4, 5, 8, 9, 10)

Descriptions of Strategies you use to-

- Organize and differentiate your instruction to meet the needs of your students

- Establish and maintain a positive, productive climate for leaming

- Minimize interruptions and distractions

Supporing Artifacts

Descriptions of Strategies you use to-

- Communicate with and involve your students' families

- Communicate with other staff members about your students' needs

Supporting Artifacts 
Descriptions of Strategies you use to-

Respond to requests from family members

- Respond to requests for information from other staff members

Ensure that you follow school-wide procedures, policies, and timelines

Supporting Artifacts

Problem-Based Reflection

Voices of Others

Summary Reflection related to your Critical Question

SECTION VI - PROFESSIONALISM

Critical Question

(Addresses Advanced Competencies 4, 5, 6, 8, 9, 10)

Descriptions of Professional Activities-

- Committee Work

* Extra-Curricular Assignments

* Membership in Professional Organizations

: Leadership Roles

Supporting Artifacts

Descriptions of Professional Resources related to the Domains-

Books

* Professional Joumals

- Web Sites

* Other

Descriptions of resources you have identified for future use

- Professional Activities related to the Domains

- Conferences

In-Service Sessions

Workshops

- Supporting Artifacts

Problem-Based Reflection

Voices of Others

Summary Reflection related to your Critical Question

SECTION VI-IN RETROSPECT

Who am I Now? Essay 
APPENDIXE

QUESTIONS FOR FOCUS GROUP DISCUSSION 


\section{QUESTIONS FOR FACULTY FOCUS GROUP DISCUSSION}

1. What do you consider to be the main goals of the Graduate Teacher Education Program?

2. In what ways to believe that GTEP prepares teachers to be teacher change agents?

3. Have there been any significant changes in the program since you have been with the program that I should consider when analyzing data from graduates of different years? 
APPENDIX F

TABLE OF ITEMIZED REPSPONSES TO TAMS 
Inservice Teachers Responses Itemized

Teacher Adaptability Measurement Scale: TAMS SCALE

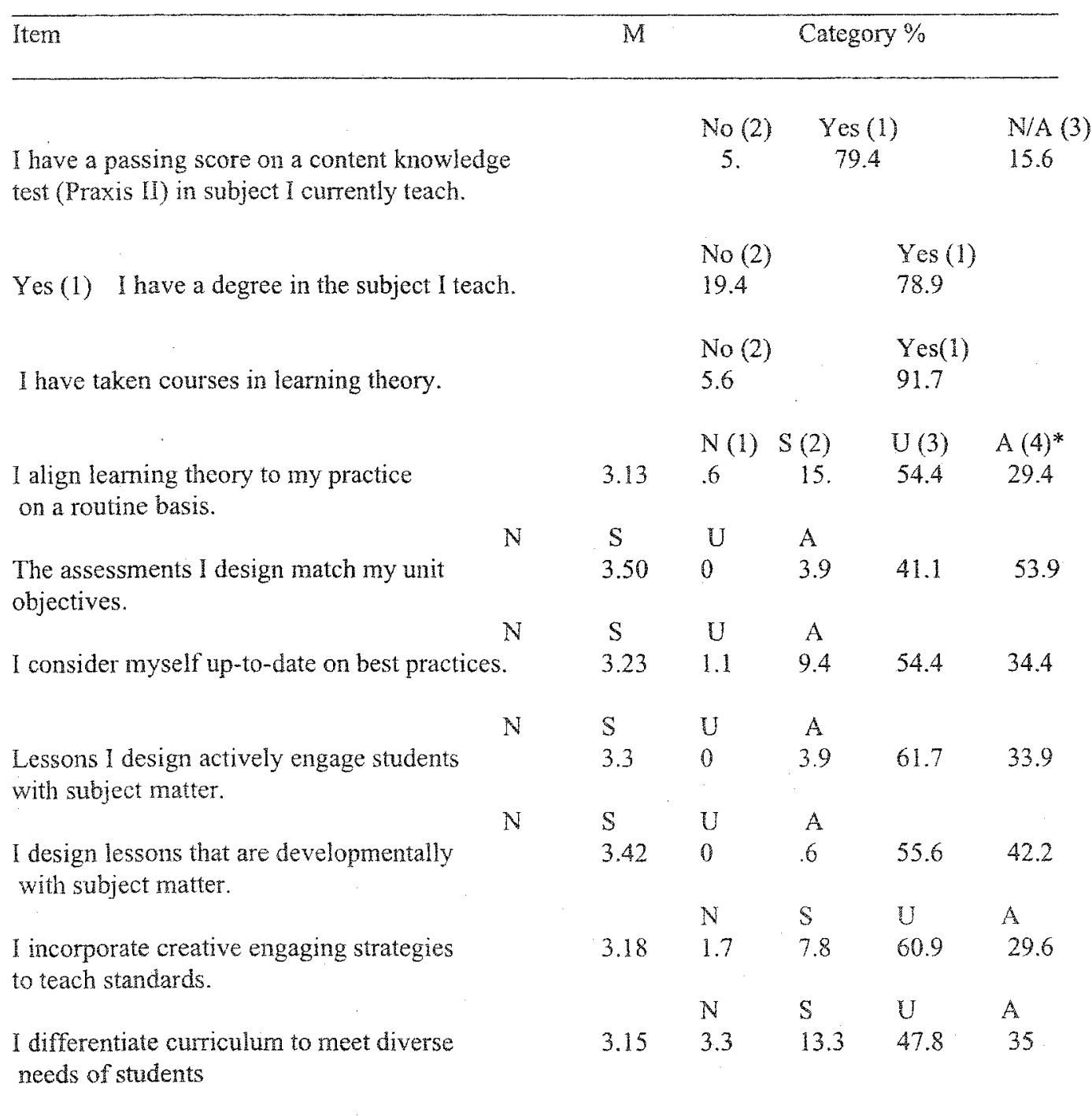

* Note: $\mathrm{N}=$ never $\mathrm{S}=$ sometimes $\mathrm{U}=$ usually, $\mathrm{A}=$ always

(Items 1-10 describe behaviors of a competent teacher) 
Inservice Teachers Responses Itemized

Teacher Adaptability Measurement Scale: TAMS SCALE (continued)

\begin{tabular}{|c|c|c|c|c|c|}
\hline \multirow[t]{2}{*}{ Item } & \multicolumn{2}{|l|}{ M } & \multicolumn{3}{|c|}{ Category $\%$} \\
\hline & 2.80 & $\begin{array}{l}\mathrm{N} \\
4.4\end{array}$ & $\begin{array}{c}\mathrm{S} \\
36.7\end{array}$ & $\begin{array}{l}\mathrm{U} \\
32.2\end{array}$ & $\begin{array}{c}\mathrm{A} \\
26.1\end{array}$ \\
\hline \multirow[t]{2}{*}{$\begin{array}{l}\text { I attend professional conferences or } \\
\text { workshops annually. }\end{array}$} & 3.10 & $\begin{array}{l}N \\
7.8\end{array}$ & $\begin{array}{l}S \\
18.3\end{array}$ & $\begin{array}{c}\mathrm{U} \\
30\end{array}$ & $\begin{array}{l}\text { A } \\
43.3\end{array}$ \\
\hline & & $\mathrm{N}$ & $\mathrm{s}$ & $U$ & A \\
\hline \multirow[t]{2}{*}{$\begin{array}{l}\text { I routinely discuss with colleagues best } \\
\text { practices. }\end{array}$} & 3.13 & 3.9 & 18.3 & 38.3 & 38.9 \\
\hline & & $N$ & S & U & A \\
\hline \multirow{2}{*}{$\begin{array}{l}\text { I invite colleagues to observe and } \\
\text { discuss my practice. }\end{array}$} & 2.45 & 13.3 & 44.4 & 25 . & 16.7 \\
\hline & & $N$ & $\mathrm{~S}$ & $\mathrm{U}$ & $\mathrm{A}$ \\
\hline \multirow[t]{2}{*}{$\begin{array}{l}\text { I communicate with parents about students' } \\
\text { learning needs. }\end{array}$} & 3.12 & 3.3 & 19.4 & 37.8 & 37.8 \\
\hline & & $\mathrm{N}$ & $\mathrm{S}$ & U & A \\
\hline \multirow[t]{2}{*}{$\begin{array}{l}\text { I invite parents and community members } \\
\text { into my room. }\end{array}$} & 2.94 & 7.2 & 30.6 & 21.1 & 39.4 \\
\hline & & $\mathrm{N}$ & $\mathrm{s}$ & U & A \\
\hline \multirow[t]{2}{*}{$\begin{array}{l}\text { I reflect on the effectiveness of my lessons } \\
\text { and unit plans. }\end{array}$} & 3.54 & .6 & 5.6 & 33.3 & 60. \\
\hline & & $\mathrm{N}$ & $\mathrm{s}$ & $\mathrm{U}$ & A \\
\hline \multirow[t]{2}{*}{ I solicit input from students. } & 3.10 & .6 & 20.6 & 46.7 & 31.1 \\
\hline & & $\mathrm{N}$ & S & $U$ & $\mathrm{~A}$ \\
\hline \multirow[t]{2}{*}{$\begin{array}{l}\text { I utilize community resources to enhance } \\
\text { my teaching. }\end{array}$} & 2.52 & 5.6 & 51.7 & 26.7 & 15.6 \\
\hline & & $\mathrm{N}$ & $\mathrm{s}$ & $\mathrm{U}$ & A \\
\hline I experiment with new strategies. & 3.11 & 0 & 20.6 & 47.8 & 31.1 \\
\hline
\end{tabular}

* Note: $\mathrm{N}=$ never, $\mathrm{S}=$ sometimes, $\mathrm{U}=$ usually, $\mathrm{A}=$ always

(Items 9-20 describe behaviors of a teacher who is lifelong learner) 
Inservice Teachers Responses Itemized

Teacher Adaptability Measurement Scale: TAMS SCALE (continued)

\begin{tabular}{|c|c|c|c|c|c|}
\hline \multirow[t]{2}{*}{ Item } & \multicolumn{2}{|l|}{$\mathrm{M}$} & \multicolumn{3}{|c|}{ Category \% } \\
\hline & & $\mathrm{N}$ & $S$ & $\mathrm{U}$ & $\mathrm{A}^{*}$ \\
\hline \multirow{2}{*}{$\begin{array}{l}\text { I get to know my students as individual } \\
\text { human beings. }\end{array}$} & 3.63 & 0 & 3.9 & 28.9 & 6 \\
\hline & & $\mathrm{N}$ & $\mathrm{S}$ & $\mathrm{U}$ & $\mathrm{A}$ \\
\hline \multirow[t]{2}{*}{ I get to know my students' family. } & 2.60 & 4.4 & 46.7 & 32.2 & 15.6 \\
\hline & & $N$ & $\mathrm{~S}$ & $\mathrm{U}$ & A \\
\hline \multirow{2}{*}{$\begin{array}{l}\text { I make the curriculum relevant to students' } \\
\text { lives. }\end{array}$} & 3.12 & 0 & 11.7 & 63.9 & 23.3 \\
\hline & & $\mathrm{N}$ & $\mathrm{s}$ & $\mathrm{U}$ & A \\
\hline \multirow[t]{2}{*}{$\begin{array}{l}\text { I incorporate my students' cultures into } \\
\text { the classroom. }\end{array}$} & 3.00 & 1.7 & 23.3 & 47.2 & 26.7 \\
\hline & & $\mathrm{N}$ & $S$ & $\mathrm{U}$ & A \\
\hline \multirow[t]{2}{*}{$\begin{array}{l}\text { I give students voice in the design and } \\
\text { curriculum content. }\end{array}$} & 2.36 & 7.2 & 55.6 & 30. & 6.7 \\
\hline & & $\mathrm{N}$ & S & $\mathrm{U}$ & A \\
\hline \multirow[t]{2}{*}{$\begin{array}{l}\text { I celebrate students' strengths as well as } \\
\text { focus on improving their weaker skills. }\end{array}$} & 3.40 & 8.9 & 42.2 & 48.3 & 48.3 \\
\hline & & $N$ & $S$ & $\mathrm{U}$ & $\mathrm{A}$ \\
\hline \multirow[t]{2}{*}{ I believe that all students can succeed. } & 3.68 & 0 & 1.7 & 28.3 & 69.4 \\
\hline & & $\mathrm{N}$ & $S$ & $\mathrm{U}$ & $\mathrm{A}$ \\
\hline \multirow[t]{2}{*}{$\begin{array}{l}\text { I seek consultation when concerned about } \\
\text { the emotional well-being of a student. }\end{array}$} & 3.76 & 0 & 3.3 & 17.2 & 78.9 \\
\hline & & $\mathrm{N}$ & $\mathrm{s}$ & $\mathrm{U}$ & A \\
\hline \multirow[t]{2}{*}{$\begin{array}{l}\text { I seek consultation when concerned about } \\
\text { the academic well-being of a student. }\end{array}$} & 3.52 & 0 & 7.2 & 33.3 & 58.9 \\
\hline & & $\mathrm{N}$ & S & $\mathrm{U}$ & A \\
\hline I run my classroom democratically. & 2.73 & 2.8 & 36.7 & 42.8 & 16.1 \\
\hline
\end{tabular}

* Note: $\mathrm{N}=$ never, $\mathrm{S}=$ sometimes, $\mathrm{U}=$ usually, $\mathrm{A}=$ always

(Items 21-30 describe behaviors of a teacher who has a sense of agency) 
APPENDIX G

TABLE OF ITEMIZED RESPONSES TO TAMS 
Teacher Adaptability Measurement Scale for Preservice Teachers:

TAMS1 SCALE

Item $\quad$ Category $\%$

Preservice Teachers $(n=102)$

I have a degree in the subject I teach.

No(1) Yes (2)

$39.2 \quad 54.6$

I have a passing score on a content knowledge test (Praxis II) in subject I currently teach.

14.4

practice on a routine basis.

I was taught how make assessments I design

match my unit objectives.

Lessons I design actively engage students with subject matter.

1.0

I was taught how to design lessons that are

developmentally appropriate.

I was taught how to incorporate creative engaging strategies to teach standards

I was taught how to differentiate curriculum

to meet diverse needs of students

I intend to attend professional

conferences and workshops

2.195 .9


Teacher Adaptability Measurement Scale for Preservice Teachers:

TAMSI SCALE (continued)

\begin{tabular}{|c|c|c|c|c|c|c|}
\hline Item & M & $S D$ & $N(1)$ & $\mathrm{S}(2)$ & $\mathrm{U}(3)$ & $A(4)^{*}$ \\
\hline $\begin{array}{l}\text { I work collaboratively with members } \\
\text { of my cohort. }\end{array}$ & 2.88 & .82 & 3.1 & 94.8 & 0 & 0 \\
\hline $\begin{array}{l}\text { I reflect on the effectiveness of my lessons } \\
\text { and unit plans. }\end{array}$ & 3.49 & .63 & 0 & 7.2 & 35.1 & 55.7 \\
\hline $\begin{array}{l}\text { I learned to utilize community resources to } \\
\text { enhance my teaching. }\end{array}$ & 1.30 & .54 & 25.8 & 72.2 & 0 & 0 \\
\hline $\begin{array}{l}\text { I get to know my students as } \\
\text { individual human beings. }\end{array}$ & 3.67 & .53 & 0 & 3.1 & 25.8 & 69.1 \\
\hline I get to know my students' families. & 2.47 & .71 & 4.1 & 51.5 & 34.0 & 8. \\
\hline $\begin{array}{l}\text { I make the curriculum relevant to } \\
\text { students' lives. }\end{array}$ & 3.13 & .62 & 0 & 13.4 & 58.8 & 25.8 \\
\hline $\begin{array}{l}\text { I incorporate my students' cultures } \\
\text { into the classroom... }\end{array}$ & 3.02 & .81 & 0 & 24.7 & 40.2 & 30.9 \\
\hline $\begin{array}{l}\text { I give students voice in the design and } \\
\text { curriculum content. }\end{array}$ & 2.63 & .82 & 5.3 & 42.3 & 34.0 & 0 \\
\hline $\begin{array}{l}1 \text { tap into students' strengths as well as } \\
\text { focus on improving their weaker skills. }\end{array}$ & 3.21 & .62 & 0 & 10.3 & 56.7 & 30 \\
\hline I believe that all students can succeed. & 3.79 & .46 & 0 & 2.1 & 16.5 & 78.4 \\
\hline $\begin{array}{l}\text { I seek consultation when concemed about } \\
\text { the emotional well being of a student. }\end{array}$ & 3.70 & .52 & 0 & 3.1 & 22.7 & 71.2 \\
\hline $\begin{array}{l}\text { I seek consultation when concerned about } \\
\text { the academic well being of a student. }\end{array}$ & 3.61 & .53 & 0 & 2.1 & 33.0 & 61.9 \\
\hline I plan to run my classroom democratically. & 3.14 & .84 & 2.1 & 21.6 & 34.0 & 39.2 \\
\hline
\end{tabular}

* Note: $\mathrm{N}=$ never, $\mathrm{S}=$ sometimes, $\mathrm{U}=$ usually, $\mathrm{A}=$ always 
APPENDIX $\mathrm{H}$

HUMAN SUBJECTS REVIEW 
Human Subject Research Review

I. Project Title \& Prospectus: The Development of Teachers - as - Change Agents within a Preservice Teacher Education Program

The American education system has two daunting challenges. First, citizens need more than the three R's to function in today's interdependent world. Educated citizens face more complex responsibilities than at any other time in the nation's history. Second, public schools ${ }^{i}$ demographics have changed dramatically. Most urban schools consist of a majority of minorities, representing multiple languages and cultural perspectives. Studies document that schools fail to reach far too many students, particularly children of color and poverty.

Schools must change to meet the needs of $21^{\text {st }}$ century students. However, many teachers do not accept the need for change; of those who do embrace change in theory, some are resistant to adopt it in practice. If teachers are not open to change, schools will be incapable of implementing significant educational reform.

The objective of this proposed study is to examine how one graduate teacher education program prepares teachers to be teacher change agents. The construct of teacher-as-change agent incorporates the research on successful implementation of school reform. In order for teachers to function as a change agent they must (a) hold teacher competence, (b) be collaborative reflective leamers, and (c) have a sense of agency. This study's findings will offer insights to teacher education program designers on how to identify the most effective means to enhance the ability of new 
teachers to develop the attributes necessary to be strong agents of change.

Specifically this study will examine Portland State University's Graduate Teacher Education Program's ability to prepare new teachers to work in a changing culture. Portland State University's Graduate School of Education redesigned its teacher preparation program in 1989. At that time, teacher education at Portland State became exclusively a graduate level option. Admissions criteria became more rigorous. A cohort model of collaboration, social constructivist instruction, and reflective practice became components of the program's design. In addition, a strong commitment to preparing teachers to work in diverse urban environments became the school's mission. The specific objective of the revised Graduate Teacher Education Program (GTEP) reads:

To develop outstanding teachers: strong in subject matter, expert in instructional decision-making and practices, and committed to educational excellence in the service of fair and humane schools and society.

GTEP has licensed over a thousand new teachers since its first cohort groups started in 1989 yet few follow-up studies have been conducted. The goals for GTEP, as described by the core faculty are, "to prepare educators who are strong subject matter experts, sensitive to the contexts in which they teach, and ready to both study and change the educational system in which they work" (Peterson et al 1991 p. 2). Is GTEP succeeding in obtaining the goal of preparing teachers to work in an environment of education reform?

The primary method for measuring GTEP's impact on the development of teacher change agents will be the comparison of data from surveys administered at 
three different stages of teacher development: (a) students completing the program, and (b) graduates currently teaching. This cross-sectional comparison will allow the researcher to examine the perceptions of teachers-as-change agents at two different stages of development.

In order to look more deeply at the actions behind the perceptions of teachers, an in-depth qualitative analysis of six continuing license portfolios will also be conducted. These portfolios will have be written by GTEP graduates who are practicing teachers currently working on their continuing teacher's license. Components of the three dimensions of the construct of teacher-as-change agents will be examined within the portfolios. Follow-up interviews will be conducted. A small focus group of veteran faculty will also be conducted to determine if any significant changes have occurred in the program that might affect the findings of this study.

Schools are under tremendous pressure to become more effective learning communities that "leave no child behind." Schools of education need to know how to prepare the next generation of teachers to respond to the significantly different requirements of the $21^{\text {st }}$ century educational landscape.

II. Exemption Claim for Waiver of Review

This study would not qualify for a waiver. It would however, qualify for an expedited review under Category 7 :

Research on individual or group characteristic or behavior (including, but not limited to, research on perception, cognition, motivation, identity, language, communication, cultural believes or practices, and social behavior) or research employing survey, 
interview, oral history, focus group, program evaluation, human factors evaluation, or quality assurance methodologies.

III. Subject Recruitment

The subjects will be GTEP graduates who are currently employed as teachers. All graduates with valid addresses will be mailed a copy of the teacher adaptability scale, with a cover letter written by the researcher. The sample for this study will be limited to those graduates who are currently working in a school setting where they have the potential to be change agents.

The sample will need to be stratified to insure there is a representational sampling of graduates teaching within different districts and with different age groups. For the qualitative analysis of CTL portfolios, the sample will be limited to those who are GTEP graduates and currently teaching in schools that are in the process of restructuring and who have self identified themselves as teacher change agents. Participants in the survey and portfolio review will receive letters explaining that the researcher is seeking insights as to the effectiveness of GTEP. They will be asked to complete informed consent forms. Informants who have shared their portfolios will have the opportunity to read the researcher's interpretation of the data for verification. No one will be required to participate in the study. (See attached informed consent form and cover letter).

\section{First Person Scenario}

I received a letter from a doctorate student at PSU inviting me to participate in her research evaluating GTEP. She explained that she would like to use some excerpts from my portfolio as part of her evaluation of GTEP. She also asked if I would be 
willing to participate in a survey of GTEP graduates and possibly a one-on-one interview. She explained that all of this research would be done with confidentiality honored. No one would be able to distinguish me from among the other subjects in the study. I was pleased to read that this would have not influence my CTL evaluation and that the research data would be used solely to evaluate GTEP, not my performance as an educator. Since I believe all good teachers should look back on their practice and reflect on its effectiveness, I was pleased to hear that GTEP is modeling best practices as they, in turn reflect back on their own program.

V. Potential Risks and Safeguards

The potential risks for human subjects in this study will be minimal. Receiving a continuing license is essential if one wants to continue teaching in Oregon. There is a possibility that a participant might feel inhibited in his/her ability to receive their continuing license if their evaluator was conducting research on them while in the program. Therefore, the researcher will not function as the facilitator of any of CTL candidates who are part of the study. Someone else will be their facilitator to insure that their evaluation for CTL will be completely separate from the evaluation of GTEP's initial licensure program. It should be clear in the invitational letter to join the study that this research is not an evaluation of them as teachers, but rather whether GTEP was able to obtain its objectives in the initial licensure program.

In order for this study to be shared with educational communities beyond Portland State University, the institution and program, as well as the individual participants will be given code names to protect their confidentiality. 
VI. Potential Benefits

The potential benefit would indirectly affect participants. If GTEP is able to learn ways of enhancing its program, teachers out in the field will ultimately receive the benefit of working with future colleagues who are well prepared to work collaboratively for the betterment of public school students.

VII. Records \& Distribution

Each participant will receive a code number that will be used for the scale, questionnaires, and in the notes taken from portfolio analysis. Each participant's school site will also receive a school code number. These records can be stored in the locked room in MISL in the Graduate School of Education for the three years required by federal regulation. 